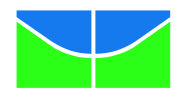 \\ Universidade de Brasília - UnB \\ Instituto de Ciências Humanas - IH \\ Departamento de Serviço Social - SER
}

Annie Vieira Carvalho

\title{
Operacionalização da Prestação de Serviços à Comunidade (PSC) e Articulação com a Rede de Atenção ao Adolescente no Distrito Federal: um Olhar da Equipe Executora
}

Trabalho de Conclusão de Curso apresentado ao Departamento de Serviço Social da Universidade de Brasília, para a obtenção do diploma de Graduação em Serviço Social, sob a orientação do Prof. Mario Ângelo Silva.

Brasília (DF), dezembro de 2009. 


\title{
FOLHA DE APROVAÇÃO
}

\author{
Annie Vieira Carvalho
}

Operacionalização da Prestação de Serviços à Comunidade (PSC) e Articulação com a Rede de Atenção ao Adolescente no Distrito Federal: um Olhar da Equipe Executora

Trabalho de Conclusão de Curso apresentado ao Departamento de Serviço Social da Universidade de Brasília, para a obtenção do diploma de Graduação em Serviço Social, sob a orientação do Prof. Mario Ângelo Silva.

Aprovado em:

\section{BANCA EXAMINADORA}

Prof. ${ }^{a}$ Mario Ângelo Silva (orientador) - Universidade de Brasília

Prof. ${ }^{\text {a }}$ Patrícia Pinheiro - Docente da Universidade de Brasília

Prof ${ }^{a}$ Carla Fernanda Silva - Docente da Universidade Católica de Brasília 
Dedico esta monografia à minha família e aos amigos que tiveram participação fundamental durante minha formação acadêmica, pelo apoio e incentivo. 


\section{AGRADECIMENTOS}

Direciono meus agradecimentos a Deus, que me sustenta a cada passo da minha vida.

Aos meus pais, Roberto Carvalho e Caetana Maria, e aos meus irmãos Roberto Filho e Jullie Carvalho, por estarem sempre do meu lado, incondicionalmente.

À Professora Ailta Barros e ao Professor Mario Ângelo Silva pela colaboração direta de ambos dispensada a mim durante as orientações para a produção desta monografia.

Aos professores do Departamento de Serviço Social, em especial a Professora Rosa Helena Stein, por terem contribuído na minha formação acadêmica e incentivado uma postura crítica frente ao contexto social, contemplando na dinâmica das disciplinas a ética profissional na teoria e na prática.

À Professora Patrícia Pinheiro e à Professora Carla Fernanda Silva, por se disporem ao convite de participar da banca de defesa desta monografia.

Ao Programa de Educação Tutorial - PET - e todos meus colegas petianos do Serviço

Social com os quais convivi durante a graduação, com a certeza de que meu desenvolvimento acadêmico dependeu das experiências nos âmbitos do ensino, da pesquisa e da extensão trabalhadas no grupo.

À equipe do PeSC/UnB, pela oportunidade de me apresentarem a Prestação de Serviços à Comunidade no tempo de estágio curricular, de onde surgiu o interesse de aprofundamento na temática.

À equipe da SEPS do Ministério Público do Distrito Federal e Territórios, pelo proveitoso tempo de estágio no qual tive contato com técnicas e abordagens desempenhadas pelos assistentes sociais que me serviram de exemplo, bem como pela convivência com os estagiários que estiveram comigo neste processo.

Às minhas amigas de curso, entre elas, Raquel Simão, Larissa Alves, Érika Laurindo, Recy Quintanilha, Quezia Cruz, Paula Rezende, Talita Aragão, Thaís Vasconcellos e

Luciana Rabelo, por terem compartilhado e aproveitado comigo todos os momentos durante a graduação, considerando que os laços de amizade vão continuar. 
"toda pessoa nasce com um potencial e tem direito de desenvolvê-lo. Para desenvolver o seu potencial as pessoas precisam de oportunidades. O que uma pessoa se torna ao longo da vida depende de duas coisas: as oportunidades que tem e as escolhas que fez. Além de ter oportunidades as pessoas precisam ser preparadas para fazer escolhas. Portanto, as pessoas devem ser dotadas de critérios para avaliar e tomar decisões fundamentadas". (SINASE, 2006) 


\section{LISTAS DE ABREVIATURAS}

AVHUB - Associação de Voluntários do Hospital Universitário de Brasília

CAPs - Centro de Atenção Psicossocial

CDCA - Conselho de Direitos da Criança e do Adolescente

CDS - Centro de Desenvolvimento Social

CONANDA - Conselho Nacional de Direitos das Crianças e dos Adolescentes

CREAS - Centro de Referência Especializado de Assistência Social

DDS - Diretoria de Desenvolvimento Social

ECA - Estatuto da Criança e do Adolescente

FUNABEM - Fundação Nacional de Bem Estar do Menor

GDF - Governo do Distrito Federal

LA - Liberdade Assistida

LOAS - Lei Orgânica de Assistência Social

MNMMR - Movimento Nacional de Meninos e Meninas de Rua

PeSC/UnB - Projeto de Prestação de Serviços à Comunidade/ Universidade de Brasília

PNAS - Política Nacional de Assistência Social

PNBEM - Política Nacional de Bem Estar do Menor

PSC - Prestação de Serviços à Comunidade

SEDEST - Secretaria de Desenvolvimento Social e Transferência de Renda

SEJUS/DHC - Secretaria de Justiça e Direitos Humanos e Cidadania

SEMSE - Seção de Medidas SocioEducativas

SENAC - Serviço Nacional de Aprendizagem Comercial

SGD - Sistema de Garantia de Direitos

SIDASE - Sistema Distrital de Atendimento Socioeducativo

SINASE - Sistema Nacional Socioeducativo 


\section{RESUMO}

Esta monografia interessou-se por analisar em que medida as equipes executoras da Prestação de Serviços à Comunidade (PSC) desenvolvem, na operacionalização desta Medida Socioeducativa, um trabalho de articulação com a Rede de Atenção ao Adolescente no Distrito Federal. A inovação da política voltada à criança e ao adolescente, trazida com os avanços legislativos da Constituição Federal de 1988 e do Estatuto da Criança e do Adolescente de 1990, foi fruto de longo processo histórico de mobilização social e mudança de paradigma em prol da Proteção Integral desses sujeitos de direitos. Considerando o contexto de violência juvenil e o envolvimento de adolescentes em situação infracional, as Medidas Socioeducativas em meio aberto surgem como uma nova forma de conferir a responsabilização destes adolescentes que cometeram atos infracionais "leves", associada à proteção e educação dos mesmos considerando sua condição especial de pessoa em desenvolvimento. Portanto, entendese que a PSC se constitui como espaço oportuno para o desenvolvimento de ações que visem garantir os direitos dos adolescentes através da viabilização de acesso às políticas públicas que atendam as necessidades dos adolescentes e de suas famílias, a fim de proporcionar uma transformação pessoal e social na vida destes jovens. Para tanto, é necessário que o trabalho das equipes de execução da PSC esteja pautado na estratégia de policy networks, ou seja, por meio da articulação em conjunto com a rede de políticas públicas disponíveis no DF. Diante destas considerações, a situação da operacionalidade da PSC no DF se encontra, ainda, instável devido a sua execução está sob a responsabilidade do Poder Judiciário (Vara da Infância), enquanto deveria ser assumida por órgão do Poder Executivo. A partir do reconhecimento conferido à relevância da vertente do trabalho articulado em redes, conferida pelo Sistema Nacional de Atendimento Socioeducativo (SINASE), na pesquisa qualitativa realizada por meio de entrevistas semi-estruturadas se constatou que as equipes de execução da PSC realizam um trabalho limitado junto à Rede de Atenção ao Adolescente no DF. Apesar do esforço da equipe técnica da SEMSE/VIJ/TJDFT em manter atualizadas as informações das instituições e serviços integrantes da rede de políticas públicas disponíveis, o limite da intervenção se concentra no encaminhamento, não havendo um acompanhamento do adolescente e de sua família. Desta maneira, percebe-se que não há laços firmados entre a rede de sistemas políticos, sendo que o Sistema Socioeducativo se restringe à tarefa de fazer o adolescente cumprir os serviços locais durante o tempo determinado judicialmente. Este fato interfere na atuação educativa da equipe de coordenadores responsáveis pelos locais de cumprimento da PSC que, diante dos limites institucionais e falta de um Projeto Pedagógico comum, não desempenham articulação com a ampla rede de políticas públicas, se atendo às parcerias nos setores dos locais de serviços. $\mathrm{O}$ Serviço Social, como profissão dedicada à garantia de direitos as classes vulneráveis por intermédio da atuação em políticas sociais, exerce papel fundamental neste processo de acompanhamento ao jovem autor de ato infracional, pois o reconhece como sujeito de direito em sua particularidade, capaz de enfrentar as conseqüências e superar os agravantes que o levou a cometer o erro, bem como o incentiva a se perceber como ator participante do meio social.

Palavras-chave: adolescente; Prestação de Serviços à Comunidade; rede de políticas públicas. 


\section{SUMÁRIO}

APRESENTAÇÃ

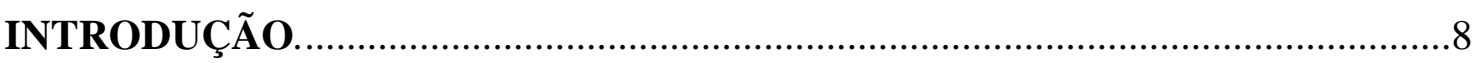

1. CAPITULO I - HISTORICIDADE DA INFÂNCIA E ADOLESCÊNCIA NO

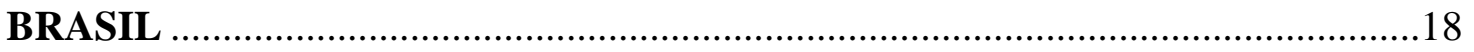

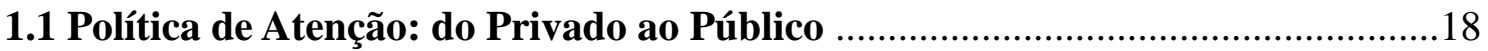

2. CAPÍTULO II - ADOLESCENTE EM QUESTÃO........................................

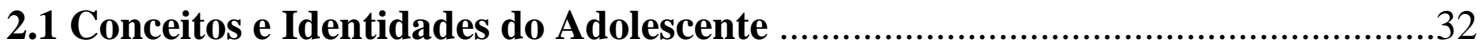

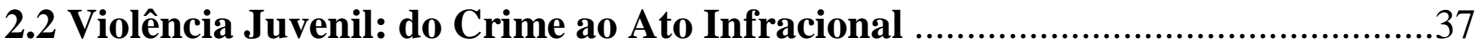

3. CAPÍtUlo III - POLÍtica DE ATENÇÃo AO ADOLESCENTE AUTOR DE ATO INFRACIONAL: RUPTURAS E REPETIÇÕES …............................43

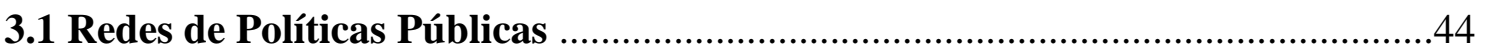

3.2 Constituição Federal de 1988 e as Políticas Sociais ...........................................53

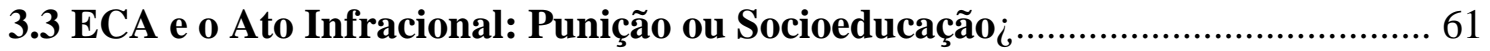

4. CAPÍtulo IV: SINASE E A PRESTAÇÃO DE SERVIÇOS À

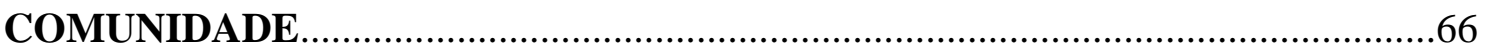

4.1 Operacionalização da PSC no Distrito Federal: Eixo de Articulação com a Rede de Políticas Públicas

5. CAPÍtUlo V - ANÁliSE DE OPERACIONALIZAÇÃo DA PSC E A ARTICULAÇÃO COM A REDE DE POLÍTICAS PÚBLICAS ...........................77

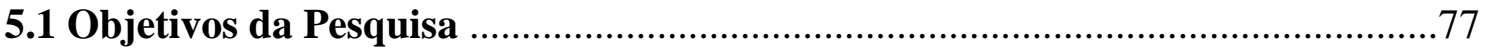

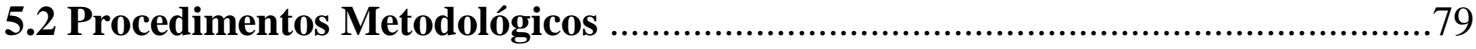

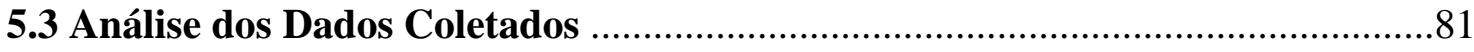

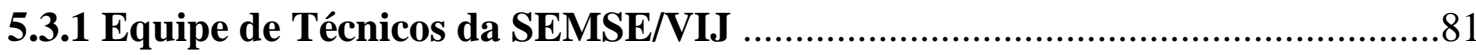

5.3.2 Equipe de Coordenadores dos locais de cumprimento da PSC .....................94

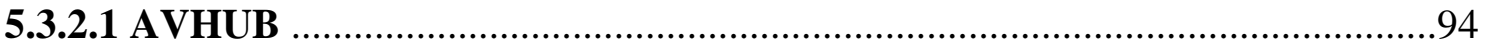

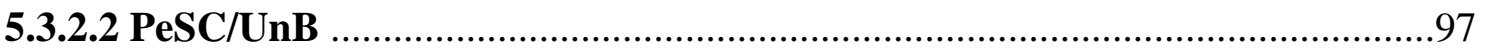

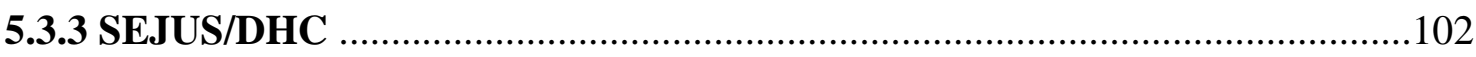

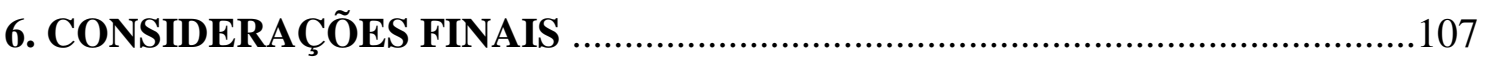




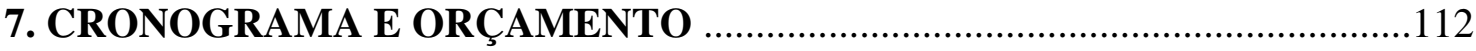

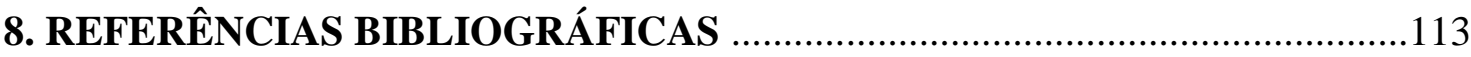

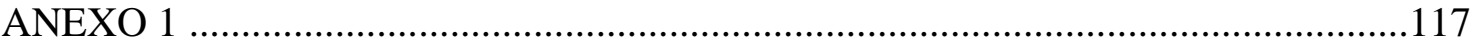

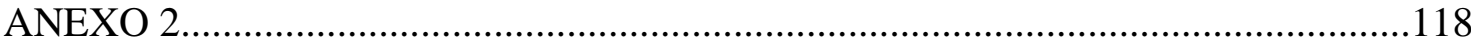

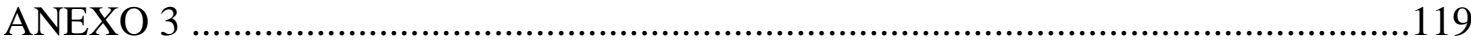

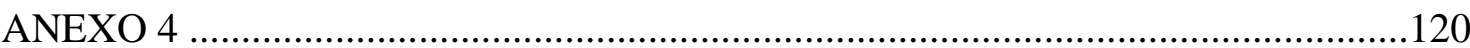




\section{APRESENTAÇÃO}

O desenvolvimento deste trabalho de conclusão de curso trata-se de um estudo científico a respeito da Medida Socioducativa de Prestação de Serviços à Comunidade (PSC) e sua relação com o trabalho articulado em redes de políticas públicas. Teve como motivação o envolvimento da pesquisadora em local de cumprimento da Medida referenciada na condição de estagiária, durante o primeiro semestre do ano de 2008. A aproximação com a realidade da operacionalização da PSC implicou em levantar questionamentos quanto aos objetivos e impactos da Medida, bem como do papel da equipe profissional envolvida na execução de tal.

O Serviço Social é considerado como profissão colaboradora nas ações integrantes da política de atenção à criança e ao adolescente, por possuir capacidade de atuação junto às necessidades sociais deste público alvo, inclusive no caso de adolescentes ditos "em conflito com a lei". Este estudo mostra-se importante na medida em que o profissional de Serviço Social é referenciado por exercer um trabalho de articulação de rede de políticas públicas, por receber formação específica que oferece embasamento teórico-metodológico propício para desempenhar um trabalho institucional de maneira articulada com outras instâncias desta rede. A PSC conta com profissionais das áreas de Serviço Social e de Psicologia, bem como voluntários da sociedade civil que devem se mobilizar para promover a reinserção social do jovem em situação infracional, aproveitando o período de cumprimento da Medida para estabelecerem um atendimento de qualidade, de acordo com as propostas legais.

A execução da PSC no Distrito Federal (DF) vem sendo aplicada sob responsabilidade da Vara da Infância e da Juventude, órgão do Poder Judiciário, em caráter provisório desde a instituição do Estatuto da Criança e do Adolescente (ECA 1990). A complexidade em torno da situação de cumprimento da PSC e das demais Medidas Socioeducativas também diz respeito à incerteza sob qual política compete sua execução, sendo que a Secretaria de Assistência Social do GDF traçou em seus programas planos de atender a demanda de adolescentes autores de atos infracionais, porém não aplicados. A partir destas colocações, faz-se relevante conhecer o empenho da equipe de execução da PSC e compreender a atual dinâmica de funcionamento desta Medida, sob o enfoque da nova tendência de articulação de instituições e serviços públicos em redes colaborativas, por entender como eixo capaz de tornar efetivo o 
objetivo da Socioeducação de transformação pessoal e social do adolescente autor de ato infracional. 


\section{INTRODUÇÃO}

O presente trabalho aborda a temática da adolescência no contexto infracional sob o enfoque da Medida Socioeducativa ${ }^{1}$ de Prestação de Serviços à Comunidade (PSC), no intuito de resgatar aspectos estruturais que compõem a constituição da política de atenção voltada ao adolescente autor de ato infracional no âmbito do Distrito Federal, essencialmente a respeito da perspectiva de rede de políticas públicas. As Medidas Socioeducativas são implementadas através de instituições do Estado e da sociedade civil, e são aplicadas por intermédio dos atores sociais engajados na operacionalização das mesmas.

Composta segundo o ideal inovador de modelo de atendimento sócioeducacional proposto pelo Estatuto da Criança e do Adolescente (ECA), a PSC integra o conjunto de Medidas Socioeducativas voltadas à responsabilização jurídica do adolescente autor de ato infracional, sendo que o objetivo central desse método pressupõe a reintegração social deste adolescente. Assim como identificado no Sistema Nacional de Atendimento Socioeducativo (SINASE, 2006), este desafio demanda por parte dos executores da PSC estratégias de operacionalização em redes que visem aproximar o adolescente do meio social através do acesso às políticas públicas disponíveis, garantindo desta forma que o jovem se entenda como protagonista de sua história.

As ações Socioeducativas possuem fundamentos na cidadania ao incentivarem a potencialização destes jovens vulnerabilizados ${ }^{2}$, na medida em que o atendimento proporciona esclarecimentos e vivência ligados à reflexão de seus direitos e deveres.

\footnotetext{
${ }^{1}$ O termo "Socioeducativo" foi empregado e adotado com esta escrita de acordo com o Sistema Nacional Socioeducativo - SINASE - (2006).

${ }^{2}$ De acordo com as considerações traçadas por Ayres (et al 2003, apud Tedesco e Liberman, 2008) o conceito de vulnerabilidade foi construído inspirado na ocorrência do surto de AIDS que assolou a população e passou a ser empregado com referência às situações problemáticas de saúde, tanto dirigido ao indivíduo quanto ao coletivo. Neste contexto de atenção à doença, a análise de vulnerabilidade era interpretada em três âmbitos: individual, social e programática; os dois primeiros com relação ao acesso às informações de saúde e participação nestes espaços, e o último sobre a avaliação de programas de atenção disponíveis a pessoa doente. Com base nesta idéia original, o conceito amplo de vulnerabilidade pode ser entendido como "a chance e risco da exposição a eventos, a possibilidade e capacidade em enfrentá-los e as suas conseqüências e inscrições na experiência individual e coletiva” (2008, p. 257). Portanto, a dimensão de vulnerabilidade está diretamente associada à capacidade sócio-individual, não restrita às privações decorrentes da pobreza.
} 
Contudo, vale considerar que o avanço incentivado na proposta Socioeducativa, de responsabilização e reinserção social do adolescente em situação infracional, foi fruto de longo processo histórico caracterizado por quebra de paradigmas. Os movimentos sociais foram importantes responsáveis por essas mudanças, ao exercerem pressão junto às autoridades governamentais na busca da construção de uma política específica voltada à infância e adolescência, necessidade esta despertada pela Constituição Federal de 1988 e confirmada pela lei de número 8.069/1990 - o Estatuto da Criança e do Adolescente (ECA) -, produções ainda em fase de desenvolvimento prático.

Desde o advento da modernidade, os padrões de convívio impostos pela urbanização no Brasil, o aumento da pauperização nas cidades e, por conseqüência, o acirramento da violência e criminalidade implicaram na desordem e envolvimento do "menor" no universo infracional. $\mathrm{Na}$ realidade, as crianças e os adolescentes "corrompidos" pelo crime eram vítimas da contrariedade entre crescimento econômico e exclusão social, calcada pelos impactos sociais do processo de divisão do trabalho, e considerados pela sociedade elitista como ameaças à lógica de desenvolvimento capitalista (DEL PRIORE; SANTOS, 2006). Nota-se como herança do histórico de medidas estatais, de controle ao conhecido "menor infrator", estigmas que perduram até os dias atuais, propagados pelos meios de comunicação e relacionados à denominação de adolescentes que se enquadram nesse contexto como "delinqüentes" e "pivetes", o que desqualifica sua essência de adolescente cidadão ${ }^{3}$.

A sociedade ainda apela por medidas de segurança pautadas na privação de liberdade $^{4}$ e segregação social destes jovens, como se estas fossem eficazes para a solução do problema da violência juvenil. Recentemente no Brasil, foi colocada em pauta uma polêmica estendida quanto ao debate a respeito da redução da maioridade

\footnotetext{
${ }^{3}$ O termo "adolescente cidadão" foi empregado no intuito de conferir e dar ênfase à amplitude da subjetividade do sujeito adolescente, sendo que sua própria posição de adolescente já lhe confere o grau de cidadão, atualmente conferido no ECA ao reconhecê-lo como sujeito de direito. Contudo, perante a sociedade o adolescente ainda é minimizado em sua importância e desqualificado em sua cidadania.

${ }^{4}$ O ECA estabelece em seu Artigo 112 Medidas Socioeducativas aplicadas aos adolescentes autores de atos infracionais, sendo que as de privação de liberdade constam nos itens $\mathrm{V}$ - inserção em regime de semiliberdade e VI- internação em estabelecimento educacional. A internação trata-se da "pena" máxima de três anos na qual o adolescente é privado em instituição responsável pela aplicação da medida. Indicada em casos excepcionais, de ato infracional gravíssimo, deveria ser sentenciada como última opção tendo em vista a reclusão e segregação do adolescente do meio social. No entanto, o apelo da sociedade por segurança e justiça leva crer que a privação de liberdade como forma legítima de solução do problema da violência juvenil.
} 
penal, diante dos fatos veiculados pela mídia relacionados ao crescente envolvimento de adolescentes autores de infrações graves em paralelo à aparente impunidade dedicada aos mesmos, o que dividiu opiniões de uma população temerosa, marcada pela ausência de segurança pública.

Considerando a inovação de princípios e diretrizes de ação trazida pelo ECA, construção materializada de discussões internacionais e nacionais dirigidas à realidade brasileira, apesar de sua recente instituição destacam-se resultados imediatos angariados com a implementação da política voltada à infância e à adolescência baseada nesta lei sob os quais se constatam a atuação de órgãos públicos específicos de proteção à integralidade destes sujeitos, dependente do apoio de políticas sociais das diversas áreas dos direitos. O ECA rompeu com as medidas punitivas impostas pelos Códigos de Menores de 1927 e 1979, e renovou o contexto de ato infracional como sendo "uma circunstância de vida que pode ser modificada, não inerente à identidade do adolescente" (VOLPI, 1999). Ao propor um atendimento Socioeducativo e fornecer direitos ao adolescente autor de ato infracional, o ECA delegou ao Estado e à sociedade o reconhecimento legítimo de que este adolescente também é um sujeito de direito em situação peculiar de desenvolvimento.

O Serviço Social, como profissão comprometida com a política de atendimento aos direitos da criança e do adolescente disposta no artigo 86 do $\mathrm{ECA}^{5}$, busca contribuir com esta nova forma de lidar com a questão do adolescente a quem se atribui autoria de ato infracional, não mais através de penas coercitivas aplicadas em regime de reclusão, mas por Medidas de responsabilização/proteção Socioeducativas, capazes de promover a correção e reinserção social deste jovem que se encontra, muitas vezes, afastado das políticas públicas. O ECA define diretrizes de ação da política de atendimento a serem investidas nas seguintes linhas:

I - políticas sociais básicas;

II - políticas e programas de assistência social, em caráter supletivo, para aqueles que deles necessitem;

III - serviços especiais de prevenção e atendimento médico e psicossocial às vítimas de negligência, maus-tratos, exploração, abuso, crueldade e opressão;

\footnotetext{
5 “Art. 86. A política de atendimento dos direitos da criança e do adolescente far-se-á através de um conjunto articulado de ações governamentais e não-governamentais, da União, dos estados, do Distrito Federal e dos municípios." (BRASIL, ECA, 1990; 2005, p. 25)
} 
IV - serviço de identificação e localização de pais, responsável, crianças e adolescentes desaparecidos;

$\mathrm{V}$ - proteção jurídico-social por entidades de defesa dos direitos da criança e do adolescente (BRASIL, ECA, 1990, Art. 87, 2005, p. 25).

Segundo o ECA, a Prestação de Serviços à Comunidade (PSC) consiste “... na realização de tarefas gratuitas de interesse geral, por período não excedente a seis meses, junto a entidades assistenciais, hospitais, escolas e outros estabelecimentos congêneres, bem como em programas comunitários ou governamentais". (BRASIL, Art.117 ECA - 1990 - 2005, p.31). O Sistema Nacional de Atendimento Socioeducativo - SINASE - (2006) surgiu da necessidade de se estruturar meios e diretrizes de operacionalização das Medidas Socioeducativas em conformidade com os princípios do ECA. Este produto contou com a participação e contribuição de diversos

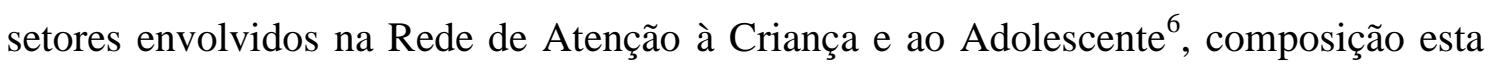
que forma o conjunto integrado de instituições participantes da política de atendimento às crianças e aos adolescentes. Dentre os objetivos traçados para tornar efetiva a aplicação das Medidas Socioeducativas, o SINASE determina como condicional a articulação das instituições de operacionalização destas Medidas com a ampla rede de políticas públicas disponíveis, responsáveis por atender adolescentes nos mais diversos âmbitos, de acordo com os princípios de universalidade, equidade e integralidade, esta última determinada pela intersetoridade e interdisciplinaridade (BRASIL - SINASE, 2006).

No Distrito Federal, a Medida Socioeducativa de PSC vinha sendo gerenciada por equipe multiprofissional da Seção de Medidas Sócio-Educativas da Vara da Infância e da Juventude do Tribunal de Justiça do Distrito Federal e Territórios SEMSE/VIJ/TJDFT -, composta por psicólogos e assistentes sociais. Os locais de cumprimento da PSC acontecem nas entidades conveniadas à VIJ, por meio de vínculo com voluntários, ou seja, funcionários que se dispõem a acompanhar o adolescente diretamente no período de cumprimento dos serviços locais ${ }^{7}$. O momento atual é de transição de instituições responsáveis pela gerência das Medidas Socioeducativas, da

\footnotetext{
${ }^{6}$ Ver esquema do Anexo 1. Cartilha da Promotoria de Defesa da Criança e do Adolescente, 2006.

${ }^{7}$ No caso do Distrito Federal, há nove instituições conveniadas à Vara da Infância e da Juventude, entre elas estão a UnB - Universidade de Brasília e AVHUB - Associação dos Voluntários do Hospital Universitário de Brasília, campos pesquisados neste trabalho.
} 
VIJ para a Secretaria de Estado de Justiça, Direitos Humanos e Cidadania SEJUS/DHC -, fato que implicará em mudanças significativas no modelo de operacionalização da política de atenção voltada ao adolescente autor de ato infracional. Enquanto, neste ano de 2009, a transferência da Liberdade Assistida já foi efetivada a encargo da SEJUSDHC, a PSC ainda encontra-se sob a responsabilidade da equipe da VIJ/TJDFT.

Diante do desafio de operacionalização das Medidas Socioeducativas mediante as novas indicações estratégicas traçadas no plano do SINASE, considerou-se fundamental verificar junto à equipe de execução da PSC seu posicionamento a respeito do trabalho articulado em redes de políticas públicas, tendo em vista a importância conferida neste componente do atendimento Socioeducativo para a transformação do adolescente. Portanto, este trabalho preocupa-se primeiramente em desenvolver um raciocínio de acordo com o processo de constituição da política de atenção ao adolescente trazendo no primeiro capítulo aspectos da historicidade da infância e da adolescência no Brasil.

Após o apanhado histórico do contexto infanto-juvenil brasileiro, o capítulo segundo vem discutir os conceitos e identidades construídos socialmente em torno da imagem do adolescente ao longo da história, a partir dos traços de seu estado físico e de sua personalidade que o faz assumir determinado papel no conjunto social, bem como as repercussões da violência juvenil. Na seqüência, o capítulo três irá abordar a Política de Atenção ao Adolescente em seu processo de construção e amplitude, a considerar o debate de rede de políticas públicas e a instituição de aparatos legais balizadores que inovaram a situação infracional através do modelo Socioeducativo, como destaque a Constituição Federal de 1988 e do ECA de 1990.

No capítulo quatro, o enfoque centra-se em esclarecimentos a respeito da Medida Socioeducativa de Prestação de Serviços à Comunidade (PSC) e aspectos de sua operacionalização, relacionado às diretrizes de execução sugeridas pelo Sistema Nacional de Atendimento Socioeducativo (SINASE) principalmente sobre o eixo de articulação em rede de políticas públicas. Finalizando, o capítulo quinto trás em seu conteúdo a análise de pesquisa realizada com os profissionais engajados atualmente nas equipes de execução da PSC no DF. Este capítulo inicia com a explicação da metodologia de pesquisa qualitativa aplicada para o recolhimento dos dados almejados. Depois, foram registradas as informações relevantes para a pesquisa e analisadas em sua essência. Nas considerações finais foram definidas as conclusões nas quais houve a 
confirmação da hipótese de que o trabalho em articulação com a rede de atenção ao adolescente executado pelas equipes de PSC é limitado no sentido do acompanhamento do adolescente. 


\section{CAPITULO I - HISTORICIDADE DA INFÂNCIA E ADOLESCÊNCIA NO BRASIL}

\subsection{Política de Atenção: do Privado ao Público}

A questão da infância e da adolescência no Brasil acompanha as peculiaridades da própria história do país, considerando a influência cultural de seus colonizadores europeus, já que seu descobrimento e exploração aconteceram no século XV. Considerando o legado histórico de padrões e representações sociais construídos internacionalmente, que foram trazidos e adaptados no Brasil, não havia distinção quanto à concepção de criança em comparação com a categoria adolescente. Sabe-se que o fenômeno da adolescência só passa a ser reconhecido como etapa constituída por especificidades a partir do século XX, através do esforço científico das áreas de Ciências Humanas e Sociais em constatar as particularidades desta categoria por meio de fundamentos teóricos, históricos, biológicos e sociais ${ }^{8}$. Além disso, consideremos nesta discussão conceitual sua relação com os interesses do jogo econômico e político, tendo em vista as conseqüentes transformações societárias na qual a criança também aparece como ator fundamentalmente integrante (FALEIROS, 2005).

Introdutoriamente, vale ressaltar na história do descobrimento do Brasil a participação peculiar de crianças estrangeiras utilizadas como força de trabalho dentro das embarcações que rumavam ao país. Na Europa, as taxas de mortalidade infantil afetavam as crianças da época, constatação conseqüente do quadro de pobreza e desigualdade social agravados pela omissão do poder público em desenvolver políticas de saneamento básico e atenção à saúde da população. A desvalorização do apego à criança por seus familiares existia como forma de preparação para o inevitável: sua morte recente. Entre os séculos XIV e XVIII "cerca da metade dos nascidos vivos morria antes de completar sete anos" (MICELI, 1994, p. 49; apud DEL PRIORE, 2006, p. 20).

O trabalho infantil era uma realidade comum, reproduzida por valores culturais segundo a ordem do trabalho, e necessário como complemento salarial às respectivas famílias carentes. Os meninos explorados nas embarcações portuguesas, reconhecidos

\footnotetext{
${ }^{8}$ Anteriormente, no século XIX, vinham sendo empregados com mais freqüência os termos "juventude" ou "mocidade" para representar o grupo de jovens pertencentes ao intervalo etário entre 14 e 25 anos de idade, equivalente à adolescência (DEL PRIORE, 2006, p. 140).
} 
como grumetes ou pagens ${ }^{9}$, vislumbravam a possibilidade do trabalho marítimo como oportunidade única de sobrevivência, desempenhando sua força de trabalho em troca de baixas remunerações para, assim, contribuírem no orçamento familiar. ${ }^{10}$ Isolada de vínculos afetivos, a criança capaz de ultrapassar a linha de expectativa de vida ${ }^{11}$ era vista pela família como instrumento laborativo, ou seja, considerado habilitado para aumentar a renda familiar. Na vivência de navegação, estes jovens eram agredidos física e psicologicamente, vítimas de violência sexual, e cedidos à prostituição como meio de se resguardarem de demais torturas, se dispondo a um explorador. $\mathrm{O}$ contexto a bordo era crítico para estas crianças que, já exploradas em sua força e violadas em sua integridade física e psíquica, se deparavam com surtos de doenças e com a fome. Diante das condições insalubres durante as navegações, os pequenos marinheiros em sua maioria vinham a óbito.

Importante citar que enquanto os meninos da época pré-moderna eram induzidos ao trabalho precoce as meninas recebiam preparação para a vida matrimonial e aos seus 12 anos eram consideradas prontas para casar. A sociedade tradicional dedicava-se em definir papéis sociais, entre homem e mulher, na qual a criança deveria se adaptar a esta lógica da maturidade. A partir destas considerações, conclui-se que não é possível identificar um universo infantil até então. Apesar do distanciamento e rejeição social em reconhecer a criança como sujeito especial em sua particularidade, entre a classe nobre havia estereótipos construídos em torno da criança ideal, comparada fisicamente ao anjo, ou ao menino Jesus, modelo do que viria a ser um adulto por natureza, adequado às regras sociais e produtivo socialmente. Em contraponto, projetava-se a imagem da criança "não ideal", pertencente às classes inferiorizadas de escravos e pobres, esta era excluída do meio social e recriminada. Nesta perspectiva, os rótulos construídos em relação às crianças identificavam-nas como meros objetos de análise de classes,

\footnotetext{
${ }^{9}$ Del Priore aponta (2006) distinção nas relações sociais a bordo entre grumetes e pagens, sendo os últimos considerados superiores aos primeiros. Os pagens eram advindos da nobreza ou de famílias pobres e, a eles eram confiadas tarefas mais amenas e dedicada proteção por parte dos oficiais. Enquanto os grumetes sofriam formas de castigo e tortura, desempenhando trabalhos como os adultos.

${ }^{10}$ Recebiam de soldo menos da metade dos marujos adultos, apesar de desempenharem tarefas braçais tão pesadas quanto os últimos. A relevância do trabalho marítimo ia além dos pouco lucro angariado, a inserção na tropa de marinheiros significava o ganho de certo status social (2006).

11 Segundo referência citada por Del Priore (SERRÃO, apud 2006), a expectativa de vida das crianças portuguesas girava em torno dos 14 anos de idade.
} 
distinguidas por sua posição social.

Durante a colonização, os grupos primitivos de índios encontrados no Brasil não foram considerados humanos pelos civis europeus. O título de inferioridade delegado aos indígenas motivou o entendimento de que eles deveriam ser protegidos de si próprios através de medidas que os tornassem ou "fiéis, escravos, ou trabalhadores" (ARANTES, 1995, p. 174). Os jesuítas, então, foram os responsáveis por propagarem a doutrina cristã aos indígenas e acompanharem-nos no processo de conversão dos mesmos. Diante da dificuldade de controlar povos sem fé, os jesuítas exerciam papel de colaboradores do governo português na medida em que impunham a cultura e costumes europeus aos povos indígenas, servindo ao mesmo tempo como "medicina da alma ou polícia cristã" rumo ao objetivo de dominar tanto as almas como as terras (ARANTES, 1995, p. 177).

Nesse diapasão, estabelecia-se um vínculo entre os padres e as crianças indígenas por meio da formação catequética, sob a ordem e supervisão do Estado português a fim de enraizar uma "legitimação religiosa" (FALEIROS, 2005, p. 02). A criança, criatura mais influenciável, recebia doutrinamento rígido caracterizado por uma evangelização baseada em vigilância e castigos. Os métodos severos de formação dos jesuítas eram necessários para prevenir o distanciamento dos "leigos" ao se comprovar que aquelas crianças, antes catequizadas, corrompiam-se com a puberdade devido a fatores como o nomadismo (DEL PRIORE, 2006).

Houve, em 1551, a separação de meninos indígenas dos colonos quando recolhidos às Casas Jesuítas no intuito de quebrar os laços familiares e aproximá-los dos padres e da fé católica num processo de extinção da cultura indígena. Nota-se desde o princípio, neste ponto, a intenção de institucionalizar a criança, privá-la do convívio público para moldá-la segundo os ensinamentos e regras cristãs. O poder exercido pelo Estado era, então, compartilhado com os ideais da igreja católica, no qual "o cuidado com as crianças índias pelos padres jesuítas tinha por objetivo batizá-las e incorporá-las ao trabalho" (FALEIROS, 2005, p. 02). Posteriormente, em 1585, a Companhia de Jesus, formada pelos jesuítas-educadores, fundou Colégios para acolher crianças índias e mestiças e propagar o ensino religioso que, diferente das Casas que eram mantidas por esmolas, recebiam investimentos diretos da coroa portuguesa. A devastação dos povos indígenas se deu de maneira lenta, na medida em que muitos índios foram dizimados ou escravizados, apesar do índio não ter sido muito utilizado como mão-de-obra escrava 
por serem considerados inconstantes e incapazes no trabalho (ARANTES, 1995).

Diante da inferioridade designada aos índios, o trabalho escravo foi fundamentalmente executado no Brasil Colônia por negros advindos do continente africano, na medida em que as terras brasileiras se mostravam ricas e produtivas, fonte de lucro a ser explorada. Os filhos dos escravos foram, então, os primeiros brasileiros naturais que constituíram a nação. Estas crianças também eram utilizadas como mão-deobra, através de sua força de trabalho barata, a partir dos seus sete anos de idade (ARANTES, 1995). Até o século XIX, 4\% dos escravos eram crianças e 1/3 delas sobrevivia até os 10 anos de idade (DEL PRIORE, 2006). Registra-se, ainda, como corriqueiro o envolvimento sexual de senhores de engenho com escravas, situação condenada socialmente, mas que gerou o nascimento de crianças bastardas, renegadas e abandonadas.

De acordo com Coelho (1997), o destino e os papéis das crianças dependiam da classe social na qual encontravam inseridas, classes estas bem segmentadas e definidas por padrões sociais da época ${ }^{12}$. O fenômeno da infância caracterizava-se como categoria explorada dentro da contradição entre capital/trabalho, na qual crianças carentes e abandonadas eram colaboradoras do processo de produção ao serem utilizadas economicamente como força de trabalho. Nos tempos de colonização brasileira houve a reprodução desta lógica, aplicada sobre uma sociedade "sem lei e sem rei", composta substancialmente por indígenas e, posteriormente, por escravos advindos como mercadorias humanas importadas, principalmente, da África para executarem trabalhos braçais nos feudos (ARANTES, 1995). Segundo Faleiros (2005), a manutenção de crianças escravas gerava mais despesas que a importação de escravos adultos, tendo em vista o fator dos últimos reporem seu valor de compra com os trabalhos prestados e o conseqüente lucro apropriado pelos senhores. Ademais, as mães escravas serviam como amas-de-leite à disposição das crianças ricas, que tinham seus filhos legítimos

\footnotetext{
${ }^{12} \mathrm{Na}$ época feudal se destacam como classes sociais hierarquicamente posicionadas o clero, representado pela Igreja católica; os senhores feudais, os grandes latifundiários detentores das terras produtivas; e os servos, trabalhadores escravizados que vendiam sua mão-de-obra barata. Com o advento do capitalismo, considera-se a perspectiva de classes sociais referenciada na teoria de Marx e Engles, derivada da divisão social do trabalho na qual as classes não seriam somente um grupo de status social, mas definidas em relações de propriedade. A burguesia representa o grupo de produtores e comerciantes, detentores dos meios de produção, e o proletariado seria o conjunto de trabalhadores explorados em sua força de trabalho pelos primeiros.
} 
separados do seu convívio.

No Brasil Colônia e Império, a infância sequer chegava a ser alvo de interesse público, merecedora de intervenção estatal e social. Sobre o abandono de crianças, fato recorrente, havia descaso por parte das autoridades em relação às mesmas. No entanto, entidades religiosas vinham assumindo o encargo de prestar assistência $^{13}$ a estas crianças, exercendo desta forma uma função social conveniente ao controle do problema. O sistema conhecido como "Roda dos Expostos" funcionava sob a administração da caridade católica, nas Santas Casas de Misericórdia, em que crianças eram constantemente abandonadas e entregues aos cuidados das freiras.

A proteção das crianças abandonadas, portanto, representava a proteção das elites incomodadas com a presença de crianças carentes, vistas como ameaças sociais. Houve, para tanto, a criação de uma rede de estabelecimentos de internação dos abandonados e delinqüentes, baseada no ensino de práticas laborais ${ }^{14}$. Dentro do ensino ministrado nas instituições religiosas de recolhimento, o incentivo ao trabalho era propagado e reproduzido para as crianças, preparadas a servirem à lógica do trabalho. Como objeto de compra, aos 12 anos de idade a criança escrava tinha seu valor de venda dobrado, período de conclusão de seu adestramento. Elas recebiam designações e eram, assim, referenciadas de acordo com suas funções, por exemplo: "Chico roça" e “Ana mucama" (DEL PRIORE, 2006). Quando não ativas no trabalho nas lavouras, as crianças escravas serviam como criadas dentro da casa dos senhores feudais e possuíam papel de brinquedos para seus filhos.

As crianças, no geral, não possuíam direito algum e aquelas escravas ou abandonadas estavam predestinadas a executarem atividades laborais, possibilidade apresentada como solução para que elas ocupem uma posição social de colaboradoras pelo único bem considerável, sua força de trabalho. Na realidade, a exploração do

\footnotetext{
${ }^{13}$ A função assistencial citada, exercida pela igreja católica sob o aval do Estado, não se constitui ainda como uma política pública. O termo foi empregado no sentido assistencialista, caracterizado por uma ação imediatista e de controle, configurando-se como caridade pública. O esboço assistencialista influenciou a constituição da atual política de assistência social, inclusive é notável identificar resquícios destas antigas raízes como a seletividade enfocada na extrema pobreza, focalização pautada por condicionalidades que solidifica a assistência social do país como strito sensu.

${ }^{14}$ Ao exemplo das Workhouses inglesas, casas de recolhimento administradas pela Igreja católica durante o período feudal, foram reproduzidas no Brasil a mesma medida baseada na Poor Laws, lei de ajuda aos pobres. A caridade direcionada às crianças abandonadas ou delinqüentes dentro das casas de trabalho era pautada na imposição de serviços como meio de adequá-las ao sistema capitalista.
} 
trabalho infantil representava fonte de lucro para os produtores e empreendedores que aproveitavam da mão-de-obra barata destes pequenos trabalhadores. Com a abolição da escravatura, as crianças antes submetidas ao regime de escravidão se depararam com a ausência de políticas de Estado capaz de absorvê-las, como a educação, por exemplo.

A sociedade tradicional do século XVII ainda não concebia a fase da infância em suas diferenças e reproduzia, por meio das famílias, a imediata interação das crianças com o mundo adulto no intuito de inseri-las nas atividades do cotidiano exercidas pelo homem trabalhador. As funções familiares de conservação dos bens, da prática de um ofício e da ajuda cotidiana deveriam ser assumidas rapidamente pelos novos membros da família por questões que tangem a sobrevivência do grupo, diante das crises e desigualdades sociais que tanto assolavam as massas excluídas e desfavorecidas pela lógica de produção, fato que limitava o estabelecimento de vínculos afetivos de aproximação entre os familiares. A própria educação da época desenvolvia em sua dinâmica métodos de ensino baseados no aprendizado prático, ou seja, as crianças aprendiam ajudando os adultos (ARIES, 1981). Tratava-se da preparação para o mundo adulto, na qual crianças eram adestradas a assumir responsabilidades ligadas ao trabalho o quanto antes, fato que projetava reflexos nas relações entre pais, filhos e sociedade.

A sociedade desenvolve processos de mudanças contínuos e complexos baseados em interesses hegemônicos, compatíveis com a realidade vigente e representados por sistemas político-econômicos legitimados, responsáveis por organizar os indivíduos e as instituições. O contexto histórico de transformações de um regime feudal para um modelo de produção industrial, acompanhado pelo desenvolvimento urbano, foi determinante para a formação do sistema capitalista iniciado na Inglaterra no século XVIII, com o advento da Revolução Industrial, regido por uma lógica de mercado adequada para servir de suporte aos novos arranjos sociais coletivos formados pelo capital, bem como para o desenvolvimento de um Estado moderno capaz de administrar os impactos sociais gerados pelo próprio sistema. Consideremos como importante partir da idéia de que:

A reprodução da pobreza é mediada pela reprodução do modo urbano das condições de vida, através da dinâmica do mercado de trabalho, da natureza do sistema de proteção social e do impacto de coesão social que é, na verdade, o que estrutura o conjunto de relações e interações entre a sociedade civil, o Estado e o mercado (LAVINAS, 2003, p. 26). 
Iniciado o processo de urbanização no Brasil tardio ${ }^{15}$, os infantes vindos do escravismo passavam a ocupar as ruas dos centros urbanos, sendo reconhecidos como "vagabundos" e "pivetes" por envolverem-se em furtos e pedirem esmolas. Estas crianças foram integradas, utilizadas e exploradas, no trabalho fabril. Diante da mudança central na arena onde as relações políticas, econômicas e sociais se procedem, são notórios os impactos sociais gerados com o advento do sistema capitalista tendo o espaço urbano como cenário. O agravamento da "questão social", categoria que diz respeito ao contexto social de pauperismo, relativo às manifestações de pobreza e desigualdades sociais ascendentes, é considerado como conseqüência societária das mudanças nas relações de trabalho impostas pelo capitalismo excludente. Os efeitos da acumulação do capital, como processo ininterrupto, e da divisão do trabalho social permeiam contradições entre classes sociais produzidas pelo Estado capitalista, evidenciadas pelas formas de exploração da classe que vive do trabalho ${ }^{16}$ e segregação daqueles incapacitados em exércitos de reserva. O "trabalho" é, portanto, a categoria central necessária para se compreender a realidade e as complexas relações sociais, tendo em vista os novos métodos maquinados pelo capitalismo para extrair o máximo de lucro da produção com base na exploração da força de trabalho ${ }^{17}$, inclusive infantil.

Instituída a República do Brasil, o Estado passa a tomar atitudes frente às questões problemáticas da infância e adota medidas de atenção, comumente definidas de políticas públicas (ARANTES, 1995). Dentre as primeiras iniciativas por parte do Estado, em 1726, destacam-se duas medidas:

\footnotetext{
${ }^{15}$ As mudanças nos modos de produção capitalista, bem como seus impactos econômicos e sociais, ocorreram no Brasil na sequência em que foram originadas internacionalmente. $O$ processo de globalização surgiu como forma de alastramento dos ideais impostos ao mundo pelo sistema capitalista dominante. A Revolução Francesa destaca-se como movimento societário impulsionador das mudanças de papéis nas estruturas da Igreja, de Estado e da família, através da reformulação de novas concepções e valores pautados no tripé Liberdade, Fraternidade e Igualdade. A Revolução Industrial foi outro evento marcante no âmbito político-econômico, ocorrido no século XVIII, que gerou transformações fundamentais no mundo do trabalho a partir da instauração do ideal capitalista.

${ }^{16}$ Ricardo Antunes (1995) refere-se ao grupo de trabalhadores submetidos à exploração da lógica produtiva fabril como a "classe-que-vive-do-trabalho", a partir da era fordista, e retrata o processo de metamorfoses no mundo do trabalho.

${ }^{17}$ O capitalismo é reproduzido com base na taxa de mais-valia, lucro excedente sobre o valor concreto da produção. A mais-valia é absorvida pelos capitalistas, detentores dos meios de produção, através da mercadoria força de trabalho que é explorada na forma de trabalho humano abstrato, ou seja, o trabalho excedente que não é pago e que gera o lucro ao valor do produto. Trata-se de um trabalho alienado.
} 
(i) coleta de esmolas na comunidade para socorro às crianças;

(ii) sua internação (FALEIROS, 2005, p. 03).

Na seqüência, em 1851, registra-se a criação de instituição asilar para Meninos Desvalidos (COELHO, 1997). O recolhimento adotado destas crianças abandonadas também era feito através do Sistema de Rodas. Com isso, a criança era obrigada a retribuir a acolhida feita, desenvolvendo trabalhos não remunerados. Aponta-se como fator determinante dos períodos até então descritos o caráter privado de tratamento dirigido aos infantes, exercido pelas organizações nas quais estes sujeitos encontram-se inseridos, como a família, as instituições de ensino e, inclusive, o Estado que atuou junto à igreja por meio de medidas de contenção e controle de jovens "desviados" das normas e condutas estabelecidas. Portanto, o Estado investiu como prioridade em ações voltadas às crianças e adolescentes provenientes de famílias carentes, sob uma atuação filantrópica junto à igreja, nas quais a desapropriação de necessidades mínimas culturais, psíquicas, sociais e econômicas era vinculada ao sinônimo de criminalidade. Considerando o posicionamento do Estado em combater a delinqüência juvenil junto às camadas pobres da população, vale ressaltar que

A política pública se fazia no interesse de proteger a honra privada, escondendo-se a ilegitimidade com um véu assistencialista/religioso, ao mesmo tempo facilitador do trabalho doméstico (FALEIROS, 2005, p. 03).

O cenário social da época de República do Brasil, diante das mudanças políticoeconômicas de divisão do trabalho industrial, apresentava quadro de explosão demográfica, aglomerados de cortiços e surtos de epidemias. As crises sociais, constituídas por exclusão social e empobrecimento das classes menos favorecidas ${ }^{18}$, impulsionaram o crescimento da criminalidade no país. Os jovens também se envolviam na onda de violência com crimes denominadamente cometidos, julgados sem distinção aos adultos pelo Código Penal. No período entre 1904 e 1906, os dados estatísticos revelam a amplitude do envolvimento juvenil em crimes, crescente no espaço urbano, sendo responsabilizados principalmente por

\footnotetext{
${ }^{18}$ Valladares (1991) define, no período que circunda a transição entre os séculos XIX a XX, como componentes das classes submersas em condições de pobreza aqueles indivíduos que não participam do mercado de trabalho fabril, portanto considerados "vadios". A criminalidade era, portanto, um problema relacionado às condições de pobreza.
} 
$22 \%$ das desordens, $22 \%$ das vadiagens, $26 \%$ da "gatunagem", $27 \%$ dos furtos e roubos, $20 \%$ dos defloramentos e $15 \%$ dos ferimentos (Relatórios da Justiça e Segurança Pública, 1904-1906 apud DEL PRIORE, 2006: 214).

A categorização jurídica de "menores", termo relacionado como ameaça à ordem pública, exigiu do Estado a criação de Casas de Correção como método punitivo a estes criminosos baseado na Pedagogia do Trabalho, onde havia valorização do binômio “ordem/trabalho agrícola" (COELHO, 1997). O Código Penal do Império já determinava o recolhimento dos menores que tivessem cometido crimes, julgados com base no discernimento dos mesmos. É a partir do período republicano que o Estado brasileiro começa a traçar políticas públicas voltadas à questão da infância, esboços ligados a ações pautadas na ideologia "médico/jurídico/policial", ou seja, personificando o menor nas categorias doente/perigoso/irregular (ARANTES, 1995, p.174). O Código Penal da República definia como pena a privação de liberdade dos menores em instituições industriais, também segundo o critério idade/discernimento ${ }^{19}$.

O Estado moderno, reconhecido como "Poder Público" (HOCHMAN, 1998, p. 33), é formado pelo conjunto político das instituições sociais e exerce, portanto, a representação social e o controle dos conflitos em âmbito público. A "coletivização" (1998, p. 29) das relações sociais, característica da sociedade moderna preocupada com o bem coletivo, demonstra a necessidade de dependência dos atores sociais para combater os problemas agravados pelo próprio sistema, interesse encabeçado pelas elites. As políticas sociais foram idealizadas como iniciativa pública para intervir nos “efeitos negativos" externos (idem, 1998) e solucioná-los em prol do bem-estar social. A saúde entendida como "mal-público"(1998, p. 28) é um problema de interesse coletivo, pois pode afetar a sociedade num todo quando não controlada. No Brasil, a reforma urbano-sanitarista colocou em pauta a discussão de formas de combate às epidemias agravadas no fim do século XIX, medidas impulsionadas pela elite temerosa com contágio das doenças e alastramento da pobreza urbana, prejudicial ao cenário moderno de evolução industrial e tecnológica. O fenômeno da criminalidade era, então,

\footnotetext{
19 “(i) Até nove anos completos: sempre irresponsáveis;

(ii) De nove a quatorze anos: podem obrar ou não com discernimento;

(iii) Mais de quatorze anos e menos de dezessete: discernimento é sempre presumido;

(iv) Maiores de dezessete anos e inferior a vinte e um anos: penalidade sempre é atenuada". (VIEIRA,1906, p. 27; apud DEL PRIORE, 2006, p. 216)
} 
relacionado diretamente às questões precárias de pobreza e de saúde, sendo contido por ações assistenciais públicas punitivas, de controle à ordem ${ }^{20}$.

No âmbito legislativo, o novo Código Penal, de 1890, trouxe poucas mudanças no trato jurídico da criança envolvida em delitos, ainda sem diferenciação significativa com o adulto penalizado. Apenas a partir do Código de Menores de 1927 que se fundamentou um amparo legal direcionado às especificidades do, ainda considerado, "menor". Apesar da culpabilidade do crime ser atribuída somente ao subjetivo grau de discernimento relacionado à faixa etária de idade do "menor", esta lei serviu de impulso para a "consolidação do aparato assistencial do Estado brasileiro" (COELHO, 1997, p.54), reconhecido inclusive pelas posteriores Constituições Federais, esboço do que viria a ser consolidado hoje nas políticas de atenção à criança e ao adolescente. $\mathrm{O}$ referido Código foi promulgado na data marcante de 12 de outubro de $1927^{21}$, como resultado legislativo demandado pelo debate internacional travado acerca da situação do menor. Adaptado à realidade nacional da época, seus fundamentos eram baseados na concepção de assistência e proteção ao menor delinqüente ou carente, portanto voltados às crianças de baixa renda consideradas incluídas no grupo de risco ao envolvimento com a criminalidade. Desde esta iniciativa de construção da política de atenção à criança e ao adolescente, ficou ao encargo da assistência pública assumir a função de garantir condições concretas de dignidade para a vida das crianças, apesar da estratégia do Código de 1927 constituir-se sob a optica da criminalização e medicação da pobreza $^{22}$.

Importante relevar o século $\mathrm{XX}$ como período propício à iniciativas de construção de medidas político-sociais em prol da infância e da juventude no Brasil,

\footnotetext{
${ }^{20}$ Segundo análise de Sonia Rocha (2000, p. 187), dentre os dez pontos identificados sobre a pobreza no Brasil, as crianças aparecem como indivíduos mais vulneráveis às condições de pobreza. Fatores como a dependência financeira e a fragilidade física apontam riscos relacionados à precariedade nos âmbitos da alimentação-higiene-saúde, além do foco educacional, sendo alertada a necessidade de políticas que venham suprir estas carências básicas.

${ }^{21}$ No dia doze de outubro comemora-se o dia das crianças, referência histórica ao avanço proposto pelo Código de Menores, por reconhecer a particularidade das crianças e dos adolescentes, antes tratados e julgados juridicamente sob os mesmos critérios dos adultos.

${ }^{22}$ Considerações feitas a partir do texto "Contexto Histórico do Código de Menores ao Estatuto da Criança e do Adolescente - Mudanças Necessárias (?)”. Disponível em: http://www.webartigos.com/articles/19148/1/contexto-historico-do-codigo-de-menores-ao-estatuto-dacrianca-e-do-adolescente--mudancas-necessarias-/pagina1.html
} 
tendo em vista os acontecimentos sociais transformados pelo progresso econômico e tecnológico do sistema capitalista vigente e seus impactos tanto positivos quanto negativos para a população. Num cenário de explosão demográfica, onde entre 1872 e 1990 a população cresceu quinze vezes, bem como num contexto paradoxal entre o processo de urbanização e o agravamento da pobreza em que reproduzia-se a exploração do trabalho exercido por crianças e existia o abandono das mesmas, "surgia a "questão do menor', que exigia políticas públicas renovadas" no intuito de romper com o caráter caritativo antes imbricado nas instituições de Misericórdia (MARCILIO, 1998, p. 192).

Os Institutos Disciplinares foram medidas estatais consolidadas para formalizar a política de repressão e contenção de jovens autores de infrações, haja vista a equivalência do termo com práticas criminosas, ainda utilizadas pejorativamente. Em 1941, o modelo de atendimento desenvolvido pelo Serviço de Assistência ao Menor SAM - foi elaborado no intuito de centralizar a assistência ao "menor em situação irregular" de maneira menos imediatista e proporcionar maior qualidade, aproveitando para:

d) recolher os menores em estabelecimentos adequados, a fim de ministrar-lhes educação, instrução e tratamento sômato-psiquico até o seu desligamento;

e) estudar as causas do abandono e da delinqüência infantil para a orientação dos poderes públicos (BAZÍLIO,1985, p. 14).

Contudo, a SAM foi extinta no bojo de seu funcionamento clientelista e corrupto. Em 1964, período de ditadura militar, a Fundação Nacional de Bem-Estar do Menor - FUNABEM - tornou-se substituta da antiga SAM, com o objetivo de implementar a Política Nacional do Bem-Estar do Menor (BAZÍLIO, 1985, p.49). Entretanto, não houve mudanças significativas na organização da estrutura política vigente, basicamente aplicada sob o regime de internação, continuando a funcionar de maneira repressiva e imediatista. Vale apontar como crucial a ideologia de Segurança Nacional reproduzida no contexto de ditadura, encabeçada pelos oficiais das forças militares, sob a óptica positivista de ordem social almejada desde a instauração da República. Observa-se durante a ditadura a expansão de políticas sociais nas qualidades de centralização de gestão do governo federal, de fragmentação funcional entre instituições, e sendo elaboradas segundo os anseios da elite.

De acordo com Bazílio (1985, p. 35), “o social é tido como um organismo 
compatível ao corpo humano, sujeito à mesma simetria e relações. Cada órgão deve desempenhar sua função para o bom funcionamento do sistema ${ }^{23}$ ". Esta citação revela posicionamento baseado à luz de corrente funcionalista, na qual o corpo social é visto como uma formação composta por partes que devem exercer suas funções específicas em harmonia. Portanto, a lógica de controle às classes e grupos sociais que atrapalham a continuidade da reprodução do capital é perpetuada na ação militar como forma de garantir "a ordem e o progresso" do país. No entanto, as instituições de recolhimento de jovens infratores representam a tentativa de correção por meio de punição aplicada por privação de liberdade, funcionado mais como forma de segregação social destes "desviados" de conduta, do que de recuperação para integração em si.

O marco histórico da crise de recessão dos anos 70 implicou no "acirramento das tensões sociais e políticas" e conseqüentes exigências sociais por medidas definitivas adequadas ao atendimento dos adolescentes infratores, atores marginalizados pelo sistema (COELHO, 1997, p. 60). O Código de Menores de 1979 foi produto das demandas sociais por uma política de atenção que considerasse as peculiaridades da infância e da juventude, e trouxe algumas considerações relevantes na medida em que os atores envolvidos passam a refletir sobre os modos de construção da política infantojuvenil. O Movimento Nacional dos Meninos e Meninas de Rua foi o segmento social, que surgiu em 1985, como força ativa responsável por exercer pressão junto ao governo em prol das questões da infância. O diálogo estabelecido entre o Estado e a sociedade, e a colaboração entre ambos, constitui-se como meio de emancipação do reconhecimento dos direitos da infância e da juventude segundo suas condições particulares.

Nos anos 80, as questões ligadas à política social direcionadas ao segmento infância e adolescência tiveram uma prática e discussão que, via de regra, colocou o Estado e a sociedade civil como parceiros na execução da política de atendimento. Com o advento das Organizações Não-Governamentais e movimentos sociais, o Estado conta com a participação de eixos da sociedade civil dedicados a colaborar com a consolidação da política voltada à infância e a adolescência, sem tirar do Estado sua responsabilidade como legítimo garantidor de direitos. Entende-se que este movimento dialético de conquistas de direitos no eixo criança e adolescente teve como impulso as

\footnotetext{
${ }^{23}$ Esta perspectiva é referenciada pela teoria funcionalista descrita por Durkheim de explicação dos fatos sociais, regras sociais que devem ser imutáveis para o bem da ordem pública.
} 
mudanças do contexto sócio-político do sistema capitalista, que atravessou momentos de crises e recuperações, proporcionando transformações de papéis do Estado e da sociedade decisivas para a implementação da Política de Atenção à infância e à adolescência $^{24}$.

O debate nacional que mobilizou instituições governamentais e nãogovernamentais no Brasil foi espelhado em discussões travadas internacionalmente a respeito do reconhecimento dos direitos humanos e de defesa à criança e ao adolescente, como também sujeitos de direitos. Instituições como a Organização das Nações Unidas - ONU/ UNICEF - aderiram e apoiaram o objetivo de promoção de políticas nacionais de defesa aos direitos das crianças e adolescentes. Em respostas a estes anseios sociais, a Constituição Federal brasileira de 1988 afirmou em seu artigo 227:

É dever da família, da sociedade e do Estado assegurar à criança e ao adolescente, com absoluta prioridade, o direito à vida, à saúde, à alimentação, à educação, ao lazer, à profissionalização, à cultura, à dignidade, ao respeito, à liberdade e à convivência familiar e comunitária, além de colocá-los a salvo de toda forma de negligência, discriminação, exploração, violência, crueldade e opressão (BRASIL, $1988 \quad-\quad$ Disponível em http://www.planalto.gov.br/ccivil_03/constituicao/constitui\%C3\%A7 ao.htm).

A partir da determinação trazida pela Carta Magna de 1988, a criação do Estatuto da Criança e do Adolescente (ECA) - lei no 8.069 de 13 de julho de 1990 surgiu como resultado da luta de vários setores da sociedade brasileira. Há uma profunda ruptura com as práticas e a mentalidade historicamente forjada em torno do personagem "menor", inclusive com os ideais repressivos dos antigos Códigos de Menores antes vigentes. O ECA reconhece, em substituição ao "menor", a Criança e o Adolescente como sujeitos alvos de proteção da mesma lei, sendo o primeiro a pessoa até doze anos de idade incompletos e o segundo aquela entre doze e dezoito anos de idade (Art. $2^{\circ}$ - ECA, 1990; 2005). Observando a situação extrema de pauperização da população, cujas conseqüências incidem diretamente sobre a infância e a adolescência, podemos perceber que a sociedade brasileira e o Estado têm como responsabilidade a operacionalização do Estatuto da Criança e do Adolescente. A referida lei inovou a Política de Atenção à Criança e ao Adolescente, agora sujeitos sociais em condição

${ }^{24} \mathrm{O}$ processo de constituição de políticas sociais, atrelado aos avanços legislativos brasileiro, será abordado em capítulo subseqüente. 
peculiar de desenvolvimento, detentores de direitos e deveres, portanto cidadãos. 


\section{CAPITULO II - ADOLESCÊNCIA EM QUESTÃO}

\section{1 - Conceitos e Identidades do Adolescente}

Segundo a concepção de Boaventura (1999), a análise de comportamento humano não tem fronteiras. Tanto o reconhecimento dos argumentos biológicos específicos quanto a perspectiva social sob o qual o homem ${ }^{25}$ encontra-se inserido, e é constituído, são de importante relevância para compreender as relações humanas consolidadas hoje com base nos contextos passados. As condições sócio-econômicas apresentadas no cotidiano seguem o compasso de um movimento dialético e constante, decorrentes dos modelos de paradigmas dominantes construídos e reconstruídos, no qual a diversidade das circunstâncias vividas historicamente pelo homem modifica e complementa as relações sociais. Ter esclarecimento, quanto às influências legitimadas de sistemas políticos no contexto social moderno, implica afirmar que o esforço das ciências naturais e sociais em traduzir as formas de conhecimento humano se completa em conceber o conhecimento sobre as condições de possibilidades, segundo sua pluralidade (SANTOS, 1999). É a partir desta concepção de análise da realidade que se pretende compreender o fenômeno da adolescência, considerando as implicações que envolvem as características físicas e psicológicas do ser adolescente, atrelado ao seu reconhecimento como sujeito social histórico.

Para Keleman "o corpo humano é o espaço aonde a experiência se dá” (1994; apud TEDESCO \& LIBERMAN, 2008, p. 259). Keleman considera a perspectiva de vida somática como sendo a vida da criança, do adolescente e do adulto. Estas etapas são visualizadas distintamente, como se o ciclo de mudanças de fases ocorresse na transferência de um corpo para outro, onde surgem crises pessoais e sociais que revelam e configuram problemas. Deste modo, no geral, considera-se o fato de encararmos com horror os momentos de transições da vida. No entanto, vale esclarecer aqui como ponto fundamental reconhecer a complexidade dinâmica da experiência humana, acumulada e articulada nas três etapas de vida definidas, na qual as mudanças e crises respectivas de cada fase se aglomeram e constituem a personalidade do indivíduo. Destaca-se que, neste processo de desenvolvimento pessoal, o homem integral em sua interação como ser social se encontra em constante transformação.

\footnotetext{
25 O termo "homem", utilizado no texto, se refere à categoria antropológica humana em toda sua diversidade, independente de especificações de raça, sexo ou faixa etária.
} 
A infância assumiu vários significados dentro das sociedades ao longo da história. Em suas características, representa um período de pouca idade, de pouca fala, ou de pouca capacidade produtiva. Infância pode ser interpretada como a oposição da idade adulta, pela falta de idade ou de identidade social. Todavia, a definição respaldada no limite de idade para personalizar determinado sujeito como "criança" pode ser problemática por estarem envolvidos na caracterização diversos fatores internos e externos influentes no nível de amadurecimento do mesmo - como a classe social, escolarização, etc. Diante do senso comum ${ }^{26}$, as concepções de infância abrangem o esclarecimento de que se trata de um período de aquisição de personalidade. Segundo Áries (1985), foi a partir do processo de industrialização que a questão da infância conquistou maior atenção por parte do Estado e da sociedade, adquirindo o reconhecimento de suas especificidades e interesse de investimento político, ao passo que nos períodos anteriores a criança era desprovida de identidade humana, sendo comparada a um "animalzinho" ou simples papel de objeto. Portanto, até o século XIX não havia distinção entre os fenômenos da infância e da adolescência, fases desconhecidas em suas particularidades, haja vista que o nascituro desde sua concepção já era visto como um "pequeno homem" que logo deveria exercer tarefas de adultos.

Em suas considerações, Carvajal (1998) parte da corrente psicanalítica de compreensão da adolescência, introduzindo a perda de sentido exato traduzido pela derivação do termo "adolescência", que surgiu a partir de "adolescer" cujo significado remete-se a denotação de "adoecer". Como etapa inevitável da vida do ser humano, o autor concebe a adolescência como etapa psicologicamente conflituosa e, por isso, desvalorizada na medida em que os recalques ${ }^{27}$ da infância e da adolescência são acumulados no processo de transição para a fase adulta, situação que significa

\footnotetext{
26 Santos (1999) aceita como possível o diálogo entre o senso comum e o conhecimento científico na intenção de criar uma "nova racionalidade", considerando o caráter conservador e legitimador do senso comum importante.

${ }^{27}$ A teoria do recalque se trata de um fenômeno psicológico que ocorre no âmbito da inconsciência, é uma manifestação de oposição às lembranças da fase de vida anterior. A infância, a adolescência e a maturidade adulta são os estágios definidos pelo autor para identificar esta forma de esquecimento, de uma fase em relação a outra, tendo em vista a necessidade psicológica de eliminar as crises vivenciadas em cada etapa. No caso da adolescência, como fase de transição da vida infantil para a adulta, há o recalque duplo acumulado do período da infância e, ainda, aquele iminente no processo de passagem da adolescência para a vida adulta. Este fato induz a compreensão da total tentativa de desprendimento das experiências vividas na adolescência pelo adulto, efeito que demonstra a intenção de eliminar da consciência a fase de crises característica da adolescência.
} 
segmentar triplamente as etapas da vida do indivíduo (entre infância, adolescência e vida adulta) e ignorar os aspectos de crises das duas primeiras fases que possam influenciar na personalidade do adulto. Para o autor, esta lógica revela o posicionamento de descaso da pessoa adulta em relação aos adolescentes e seus interesses específicos, tendo em vista o próprio distanciamento criado psicologicamente pelo adulto, mesmo este último tendo vivenciado a fase de adolescente já que ele não mais se reconhece como tal.

Ainda com base nas referências da psicanálise, o fenômeno da adolescência é entendido como momento pessoal de busca por uma identidade própria, fase de organização das defesas sexuais e tem como marco factível a separação dos pais na passagem seguinte da autosuficiência e independência características da etapa adulta. Contudo, uma análise crítica da complexidade da adolescência demanda considerar, além dos aspectos psicológicos individuais, a realidade social de interação vivenciada pelo indivíduo adolescente, compreendido como ser social participante de uma estrutura familiar e social, portanto ator responsável por desempenhar diversos papéis de acordo com seu meio de integração social ${ }^{28}$.

Conforme definido por Carvajal (1999), sua análise psicológica do adolescente permitiu definir três etapas consecutivas e distintas, em suas características, de crises enfrentadas neste período de vida, são elas: a puberal, a nuclear e a juvenil. ${ }^{29}$ No entanto, o conflito central enfrentado pelo adolescente corresponde à distância entre as suas necessidades reais e as possibilidades disponíveis no seu ambiente de convívio pessoal e social suficientes para suprir aquelas necessidades. Considera-se aqui como "necessidades sociais" equivalente à noção de direito ampliado, baseado nos princípios de liberdade, equidade e justiça social valorizados no século $\mathrm{XX}$, e distinto do termo "mínimos sociais", corriqueiramente empregado num sentido individualista vinculado exclusivamente à pobreza absoluta (PEREIRA, 2007, p. 17).

Para Carvajal, o perfil da cultura ocidental "cria impossibilidade do jovem assumir de modo responsável o papel de adulto mãe/pai” (1999, p. 34), pois recria um

\footnotetext{
28 O adolescente como ser social interage em diversos espaços, reconhecidos por Althusser como os aparelhos ideológicos de Estado. A família, a escola, o trabalho, a igreja, são exemplos destas instituições de socialização e que existem como lócus de controle do Estado.

29 Ver quadro demonstrativo de Carvajal (1999) no anexo 2.
} 
ciclo de pais desligados e crianças produzidamente viciadas, transformando-os em adultos incompreensivos. Todavia, o grande empecilho observado nas relações sociais da sociedade ocidental encontra-se no pouco poder atribuído ao adolescente para que ele exerça seu próprio papel. Há poucos espaços sociais de expressão abertos ao exercício do protagonismo juvenil, motivo exatamente reproduzido por uma sociedade que exclui o adolescente por considerá-lo incapaz e problemático.

Diante da irrelevância social em relação ao adolescente, o mesmo busca ser reconhecido por sua imagem e colocar suas atitudes em evidência por meio da inserção em grupos. É através da conquista de ser incluído em um grupo constituído de membros semelhantes que o adolescente satisfaz sua necessidade de aceitação social. O intuito de formação de grupos vinculados por laços de amizade é alcançar visibilidade perante uma sociedade que esquece a potencialidade individual do adolescente, fato ocorrido na maioria dos espaços públicos, inclusive dentro do seio familiar. Segundo Carvajal (1999) a gangue é um exemplo de grupo deformado de adolescentes reunidos com o propósito de formular um status social de invencibilidade através de atitudes violentas.

... a gangue é um grupo que tem como meta um enfrentamento violento e direto com as normas estabelecidas. $\mathrm{O}$ ressentimento, o desejo de colocar em ação tudo o que é percebido como prazeroso mas que, em geral, está submetido a uma proibição social, faz com que estes adolescentes se unam para, de comum acordo, agirem no terreno dessas proibições $(1999$, p. 87).

O envolvimento de adolescentes em gangues é um exemplo do quão frágil encontra-se a mobilidade do jovem em se relacionar através de redes sociais. $\mathrm{O}$ adolescente dispõe de uma gama de espaços socializantes nos quais compõem o conjunto de redes sociais de interação e acolhimento do mesmo, como a família, a escola, a igreja, entre outros. No entanto, nota-se a perda destes vínculos tanto afetivos quanto em termos de acesso a estes espaços, principalmente pelo fato do adolescente não se sentir como membro fundamental, sendo descartável, por problemas instaurados em cada lócus seja por dificuldades sociais que garantam sua participação ou por ausência de valores que preservem estes vínculos.

A quebra dos laços das redes sociais gera como consequiência a atitude do adolescente em buscar alternativas ilícitas de enquadramento social, colocando-se em sujeição às situações perigosas de violência. A partir daí, o jovem pode acarretar problemas de drogadição, de abandono familiar, e implicações infracionais. Conclui-se 
que as condições sociais sob as quais os adolescentes se inserem são determinantes para definir sua relação com as redes sociais disponíveis em seu meio, o que implica considerar a quebra dos vínculos sociais como ameaça à conduta do jovem que necessita atuar ativamente na sociedade. Os casos de adolescentes que rumam pelo caminho da violência significa considerar que eles foram "violentados" por um sistema excludente $^{30}$, do qual são vítimas de um ciclo que os atormentam desde sua origem, formado em "bola de neve" pelo acúmulo de conflitos e privações de âmbito social.

O ideal de democracia organizado em regras sociais apresenta tensões de ordem cultural que são enraizadas e reproduzidas nas relações sociais. Neste sentido, a definição de papéis sociais limita a construção da identidade do adolescente que, impedido de alcançar uma personalidade própria, extrapola as linhas da legalidade devido às imposições culturais que o leva a almejar enquadrar-se no mundo adulto. Portanto, concorda-se com a definição de Levisky (1997, p. 18) da "cultura como expressão de uma violência", reflexo de uma sociedade globalizada e marcada por simbolismos que impõe responsabilidades ao adolescente na intenção de transgredi-lo rapidamente à fase adulta. $\mathrm{O}$ resultado deste controle sutil em torno da imagem do adolescente, reproduzido culturalmente pela sociedade, é uma possível instabilidade no processo de auto-afirmação do mesmo.

Considerando o fato do adolescente se relacionar com seu meio social, na construção de sua qualidade pessoal, o jovem absorve valores e posturas incorporadas ao seu cotidiano que podem influenciar na sua identificação com condutas violentas, haja vista a velocidade social exigida de definição de identidade, prejudicial à capacidade reflexiva deste adolescente que se vê pressionado a assumir uma posição na sociedade (LEVISKY, 1997). A partir destas considerações, entende-se que o adolescente não goza de sua liberdade e tenta conquistá-la por métodos recriminados como rebeldia, fato que se agrava a depender do contexto social do jovem e das ferramentas de oportunidades disponíveis para tal.

\footnotetext{
${ }^{30} \mathrm{O}$ conceito de exclusão foi empregado em seu sentido amplo, não restrito ao contexto de pobreza, com base nas considerações de Lavinas (2003) que afirma que "a tônica da exclusão é dada pelo empobrecimento das relações sociais e de redes de solidariedade" (2003, p. 38).
} 


\section{2 - Violência Juvenil: do Crime ao Ato Infracional}

O processo de urbanização no Brasil ocorreu paralelamente à industrialização do país, como demanda estrutural do sistema capitalista perpetuado mundialmente em adaptar a sociedade republicana à nova ideologia da divisão do trabalho social e, assim, reproduzir a lógica de mercado burguês. A abolição da escravatura significou um avanço social estratégico e vantajoso para a constituição da imagem moderna do país, no qual a imigração de estrangeiros de diversas nacionalidades transformou o quadro social das cidades (DEL PRIORE, 2006, p. 212). A modernidade urbana representou a evolução de uma sociedade antes camponesa, vinculada às terras, para uma libertação promissora proporcionada pelo capital possuidor de valor de troca, que confere poder aos detentores dos meios de produção. Paralelamente ao crescimento urbano e econômico do país, houve uma explosão demográfica neste período de início de República $^{31}$, fato que complicou as condições sociais da cidade, incapaz de comportar dignamente todos os habitantes, a maioria segregada em cortiços. "As pestes e as epidemias se alastravam, beneficiadas pela ausência de condições mínimas de salubridade e saneamento" (idem). É neste contexto que a criminalidade aparece como um problema social, associada à concepção higienista de patologia a ser combatida/reprimida.

Os novos padrões sociais, reproduzidos a partir da democracia da modernidade, impunham regras à sociedade pautadas nos ideais de "ordem e progresso", nas quais se demandava uma postura de proximidade e vistoria do Estado para o mantimento harmônico da estrutura capitalista urbana. As ruas situavam espaços de risco à reprodução da lógica burguesa, pois comportavam a presença de "vagabundos" e "ladrões" que representavam perigo iminente às classes ricas. Desde então, a população demandou do Estado uma intervenção mais incisiva no controle de ameaças como os crimes cometidos, inclusive por "jovens delinqüentes" da época ${ }^{32}$. A criminalidade infantil passou a ser fiscalizada pela segurança de Estado e os "pequenos criminosos"

\footnotetext{
31 Dados demográficos de São Paulo dos seguintes anos: 1870 - 30 mil habitantes; 1907 - 286 mil habitantes (DEL PRIORE, 2006, p. 212).

32 Os crimes cometidos por "menores" eram, geralmente, por desordens, vadiagem, embriaguez e roubos. Representam menor agressividade, comparado aos delitos cometidos por adultos, e tratava-se de artimanhas para garantir a própria sobrevivência destes jovens, diante da precariedade na qual se encontravam expostos. (2006, p. 212).
} 
também eram julgados conforme seu grau de discernimento definido nos Códigos Penais do Império e, posteriormente, da República, sendo aplicadas as devidas penas, assim como julgados os adultos.

Uma das causas do aumento espantoso da criminalidade nos grandes centros urbanos é a corrupção da infância que, balda de educação e de cuidados por parte da família e da sociedade, é recrutada para as fileiras do exército do mal (BONUMA, 1913, p. 47; apud DEL PRIORE, 2006, p. 215).

Entender o fenômeno da violência no contexto da infância e adolescência importa reconhecer a trajetória social deste público e entendê-los como "violentados". A própria violência é legitimada socialmente pela ação de autoridades estatais que na prática intervencionista aplicam meios violentos de repressão e controle, inclusive respaldados por leis criadas para tal objetivo. Daí vem a tradicional intervenção do Estado que é reproduzida de geração à geração num ciclo vicioso pelo uso legítimo da força, alastrando este efeito para os espaços sociais de inserção da criança e do adolescente violentados, como a família. A função intervencionista demandada e legitimada socialmente, no qual confirma o "Estado como administrador dos corpos" (PASSETTI, 1999, p. 22), surgiu como alternativa de solucionar os problemas sociais relativos às condições de pobreza agravados com a urbanização e ligados à causa das ocorrências infracionais que tanto ameaçavam a ordem pública almejada pelas elites.

Atualmente, o cenário brasileiro democrático se denomina balizado por um sistema neoliberal de política, no qual o Estado desempenha seu papel de interventor compartilhadamente com a sociedade, convocada a desempenhar funções de formuladora e executora de políticas capazes de minimizar os problemas sociais. Para Passetti (1999), mesmo delegando certa autonomia à sociedade em participar das políticas sociais, este Estado neoliberal ainda exerce autoridade sob a função interventora do antigo modelo de Estado de Bem-Estar Social devido ao fato de sua atuação se dar na dimensão da institucionalização, ou seja, por conta das políticas sociais promovidas serem aplicadas por intermédio das instituições criadas e controladas pelo próprio Estado. A respeito da política voltada ao atendimento de adolescente autor de ato infracional, nota-se o distanciamento da sociedade que transfere a responsabilidade ao encargo do poder judiciário e das autoridades de segurança pública, seja por delegar total confiança na relação poder/saber conferida nas instituições citadas ou por, ainda, carregar estigmas quanto a situação irregular do 
"menor" e considerar como medida justa de segurança a "marginalização" deste infrator em instituições de privação de liberdade.

No caso de jovens em contexto infracional, estes espaços de ação estatal foram fundamentados em sua criação segundo a lógica econômica de "integração social dos futuros cidadãos", no sentido de enfrentamento às situações de pobreza vistas como causas do problema (PASSETTI, 1999, p. 23). Após momentos anteriores de medidas assumidas pela caridade católica e por institutos filantrópicos de proteção à infância, o objetivo central das instituições estatais de atendimento a crianças e adolescentes é atuar no eixo pobreza/criminalidade, no intuito de evitar o alastramento da criminalidade devido às condições de pobreza. Passetti (2008) aponta o Código de Menores, legislação jurídica instituída no ano de 1927 voltada especificamente aos jovens autores de infrações, como precursor da continuidade da política de atenção ao adolescente se dá sobre o enfoque da relação entre o conflito com a lei e a pobreza. $\mathrm{O}$ autor critica a postura do Estado tradicional e a qualidade das políticas sociais em selecionar o público alvo merecedor de tal intervenção estatal àqueles envolvidos em situações de extrema pobreza, o que justifica a ineficiência destas políticas considerando as mudanças societárias ocorridas que modificaram a qualidade dos segmentos sociais para além dos agravantes sócio-econômicos.

Atualmente, os "novos miseráveis" (PASSETTI, 1999, p. 26) pertencem à classe de trabalhadores ilegais, autônomos e bem remunerados. Eles encontram-se à margem do acesso às políticas públicas das quais tem direitos, importando a satisfação de suas necessidades básicas ${ }^{33}$ por meio da obtenção de bens de consumo que garantam sua sobrevivência. Portanto, como membro desta nova configuração social, se supõe que o adolescente envolvido em ocorrências infracionais não necessariamente é vítima das condições de pobreza por pertencer às classes menos abastadas, mas sim considerá-lo como "violentado" devido à fragilidade dos espaços de sociabilidade que constituem

\footnotetext{
${ }^{33}$ Segundo definição de Gougth (apud Lavinas, 2003, p. 31) necessidades básicas estão associadas a "todo pré-requisito de cunho universalista indispensável à participação dos indivíduos no desenrolar de sua própria existência". O conceito de satisfação do "ótimo" das necessidades básicas é considerado para além da idéia de atendimento de mínimos sociais, mas corresponde à contemplação da cidadania do indivíduo em seus direitos sociais.
} 
sua rede social, tanto por parte de sua família quanto pelo Estado ausente e autoritário que utilizam a violência de forma legítima, respalda por leis que privilegiam o controle social punitivo e desprezam as particularidades individuais. Assim como afirma Passetti, “... em nome da defesa dos direitos das crianças e dos adolescentes se legitima uma crescente economia política da pena” (1999, p. 50).

Identificado o Estado e a família como violentadores de crianças e adolescentes (PASSETTI, 1999), a sociedade em si também se apresenta como reprodutora de agressões destinadas a estes jovens na medida em que a opinião pública sustenta a legitimidade cultural do uso da violência. A mídia, representada pelos meios de comunicação e considerada como dispositivo formador de opiniões, presta serviços ao Estado e às elites que controlam as informações e reproduzem concepções que afetam a imagem da criança e do adolescente. Apesar dos avanços legais e da ruptura teórica de antigos paradigmas discriminatórios empregados contra o público infanto-juvenil, grupo antes denominado de "menores", observa-se a manutenção de perspectivas ligadas a qualidade da infância e da adolescência que são consideradas distintamente conforme a posição social.

De acordo com a categorização definida por padrões sociais, as "crianças" são aquelas pertencentes às famílias bem estruturadas, já os "menores" são identificados como pertencentes à categoria da infância desviada, corrompida ou delinqüente. Estes modelos caricaturados de identidades foram padronizados no intuito de distinguir os indivíduos de mesma faixa etária entre os que se enquadravam nos moldes sociais (crianças) e os que representavam perigo à ordem pública (menores), numa época em que cabia à intervenção sanitarista e à esfera jurídica fiscalizar e controlar a categoria "menor" (MARCÍLIO, 1998). A mídia sensacionalista veicula e reproduz a imagem de crianças e adolescentes conforme as antigas concepções discriminatórias, que são socialmente aceitas, o que gera a segregação social dos jovens taxados pejorativamente de "menores", termo que denota vínculo com conflitos e problemáticas pessoais que personificam o indivíduo por tais características, portanto não são merecedores de compor o grupo societário.

\footnotetext{
${ }^{34}$ A categoria "menor" passou a ser considerada dominante como referência despersonificada às crianças alvo de intervenção jurídica. São os antigos "órfãos", "expostos", "abandonados", "viciados", "vagabundos", "delinqüentes" (MARCÍLIO, 1998, p. 195).
} 
No tempo de ditadura militar brasileira, sob a ordem da ideologia de Segurança Nacional, o Estado moveu estratégias de ação para conter a ameaça pública que os “menores" representavam, esforço de construção da Política de Bem-Estar do Menor. Os enfoques desta política atuavam em três esferas a serem investidas: a) na conduta anti-social do menor, que deveria ser controlada; b) em ações preventivas na comunidade, com a implementação de projetos de promoção social; c) na instituição de Fundação de Bem-Estar do Menor - Funabem. Estas medidas estatais pressupunham a transformação de identidade do então "menor", induzindo sua mudança por um controle pedagógico realizado pela instituição de internação, a Funabem. Desde então, é conferida legitimidade às instituições totais ${ }^{35}$ como estruturas fundamentais no atendimento do adolescente autor de ato infracional, investimento demandado socialmente inclusive na aplicação atual da Política de Atenção ao Adolescente.

Desprovido de sua identidade e passivo do exercício de sua cidadania, o adolescente envolvido em situação infracional desconhece das leis que o protege bem como do seu valor conferido por elas. Violentados pelos mecanismos de controle do próprio sistema que os alienam e os segregam, os adolescentes não reconhecem seu potencial de sujeito de direitos e delega à representação jurídica aplicar e controlar a medida cabível em caso de ato infracional, tendo o primeiro contato com seus direitos nesta circunstância de conflito. No entanto, apesar dos avanços conferidos no Estatuto da Criança e do Adolescente ainda é possível, na prática, "identificar infração como crime e medida sócio-educativa como pena, reproduzindo sob o pretexto educativo o sistema penal” (PASSETTI, 1999, p. 16). Apesar das falhas, considera-se de suma importância a primazia do Estado em promover políticas públicas de atenção voltadas a crianças e adolescentes, por se tratar de uma dívida social necessária de ser ressarcida, bem como investir na aplicabilidade dos princípios e diretrizes do ECA de forma a garantir a efetivação dos direitos destas pessoas em desenvolvimento.

\footnotetext{
${ }^{35}$ De acordo com Goffman, instituições totais são estabelecimentos fechados, física e simbolicamente, como uma barreira à relação social por conter o sujeito preso num determinado espaço (BAZILIO, 1985, p. 42).
} 


\begin{tabular}{|c|c|c|c|c|}
\hline & \multirow[t]{2}{*}{ Adolescência } & \multicolumn{3}{|l|}{$\begin{array}{l}\text { Características das } \\
\text { crises }\end{array}$} \\
\hline & & Crise sexual & $\begin{array}{l}\text { Crise de } \\
\text { identidade }\end{array}$ & $\begin{array}{l}\text { Crise de } \\
\text { autoridade }\end{array}$ \\
\hline $1^{\mathrm{a}}$ etapa & Puberal & $\begin{array}{l}\text {-introversão liberal } \\
\text { - auto-erotismo } \\
\text { - amizade íntima } \\
\text { - hipoinvestimento do } \\
\text { ego corporal }\end{array}$ & $\begin{array}{l}\text {-confusão } \\
\text { - regressão } \\
\text {-ambivalência } \\
\text { - dessimbiotização }\end{array}$ & $\begin{array}{l}\text {-isolamento } \\
\text { - desobediência } \\
\text {-evitação } \\
\text {-desidealização }\end{array}$ \\
\hline $2^{a}$ etapa & Nuclear & $\begin{array}{l}\text { - superinvestimento } \\
\text { especular nacisista } \\
\text { - namoros } \\
\text { compartilhados }\end{array}$ & $\begin{array}{l}\text { - onipotência } \\
\text { grupal } \\
\text { - self } \\
\text { compartilhado } \\
\text {-moda }\end{array}$ & $\begin{array}{l}\text { - organização em } \\
\text { gangues } \\
\text {-rebelião } \\
\text { - ruptura } \\
\text { normativa: } \\
\text { antiadulto }\end{array}$ \\
\hline $3^{a}$ etapa & Juvenil & $\begin{array}{l}\text {-heterossexualidade } \\
\text { - escolha de parceiro } \\
\text { sexual }\end{array}$ & $\begin{array}{l}\text { - individualidade } \\
\text { - intimidade } \\
\text { - independência }\end{array}$ & $\begin{array}{l}\text { - reparação } \\
\text { - reconciliação } \\
\text { com os pais }\end{array}$ \\
\hline
\end{tabular}

Fonte: Carvajal, G. Tornar-se adolescente. 1999, p. 69. 


\section{CAPÍTUlO III: POLÍTICA DE ATENÇÃO AO ADOLESCENTE AUTOR DE ATO INFRACIONAL: RUPTURAS E REPETIÇÕES}

Atualmente, as crianças e os adolescentes brasileiros contam com seus direitos reconhecidos por amparo legal, construído ao longo da história do país, legitimado socialmente e pautado no princípio fundamental da Proteção Integral de tal público através da lei de $n^{\circ}$ 8.069/1990, intitulada de Estatuto da Criança e do Adolescente (ECA). A operacionalização da lei em questão ocorre através de um conjunto de órgãos, entidades, programas e serviços que conformam o Sistema de Garantia de Direitos (SGD), direcionado a todas as crianças e adolescentes (BRASIL - SINASE, 2006). No bojo desse fato, faz-se necessário considerar que esta conquista foi obra de processo social, liderado por movimentos de defesa em prol dos direitos da infância e da juventude, desenvolvido numa arena de interesses entre Estado e sociedade civil, cuja discussão central da "questão do menor" teve de ser repensada diante das transformações do cenário político-econômico internacional e nacional.

No Brasil, a mobilização em torno dos direitos da infância e da adolescência se estendeu à sociedade civil, bem como às organizações do Terceiro Setor, a partir da década crucial de 80, quando se consolidaram movimentos como o pioneiro Movimento Nacional de Meninos e Meninas de Rua, surgido em 1985. As formas de participação social como a Frente Nacional de Defesa dos Direitos da Criança e do Adolescente, de 1986, enriqueceram o debate em torno da garantia de direitos da infância, inclusive exercendo pressão junto às autoridades para fazer assegurar, no processo de elaboração da Constituição Federal (CF) de 1988, a garantia de direitos através de políticas direcionadas ao público infanto-juvenil segundo suas particularidades.

As iniciativas sociais citadas ocorreram como resultados das mudanças de papel do Estado que, após seguidas crises econômicas e a partir da promulgação da nova Constituição Federal de 88, viu-se frente ao desafio de consolidar um novo modelo de Seguridade Social fundado sobre três pilares (Saúde, Previdência e Assistência Social $\left.^{36}\right)$. Dentre as várias conquistas asseguradas por compromissos assumidos pelo

\footnotetext{
${ }^{36}$ Constituição Federal de 1988, Art. 194: "seguridade social compreende um conjunto integrado de ações de iniciativa dos Poderes Públicos e da sociedade, destinadas a assegurar os direitos relativos à saúde, à previdência e à assistência social. http://www.planalto.gov.br/ccivil_03/constituicao/constitui\%C3\%A7ao.html
} 
Estado brasileiro, a CF firmou em seu texto o dever de garantia dos direitos de crianças e adolescentes, como descrito no Artigo 227 da constituinte:

Art. 227. É dever da família, da sociedade e do Estado assegurar à criança e ao adolescente, com absoluta prioridade, o direito à vida, à saúde, à alimentação, à educação, ao lazer, à profissionalização, à cultura, à dignidade, ao respeito, à liberdade e à convivência familiar e comunitária, além de colocá-los a salvo de toda forma de negligência, discriminação, exploração, violência, crueldade e opressão.

Mediante ajustes de políticas de proteção social, o Estado neoliberal vigente passou a atuar de maneira compartilhada, delegando responsabilidades à sociedade civil no enfrentamento das desigualdades, agravadas pelo próprio sistema capitalista, através de novas estratégias de materialização de políticas públicas e de contextualização em redes. Posto isso, a nossa Constituição de 1988 se consagra como material precursor do propósito de consolidação do modelo de Estado de Bem-Estar inglês, adequado a processar as novas demandas sob a perspectiva $e x$ ante $^{37}$ de identificação e solução de problemas, pois engloba em seu conteúdo parâmetros de ação voltados à perspectiva de ampliação da cidadania no país, inclusive com relação às crianças e aos adolescentes tão afetados historicamente por injustiças.

\subsection{Redes de Políticas Públicas}

O termo "Bem-Estar", utilizado para classificar a antiga configuração da política de atenção à criança e ao adolescente ${ }^{38}$, taxados simplesmente por "menores" pelos Códigos de 1927 e 1979, demonstra a centralidade correspondente ao ideal político de Estado de Bem-Estar processado primeiramente em países como Inglaterra, Alemanha e França. Esse legado se deu em período de reestruturação das instituições do capitalismo, incluindo o Estado como representante e organizador da sociedade, devido a real necessidade de mudança do papel estatal frente à intensificação da questão social.

O Welfare State inglês consolidou-se na época do $2^{\circ}$ pós-guerra mundial, por influência dos ideais de pleno emprego e de investimentos em políticas sociais formulados por Keynes, em função da ineficácia da ação do modelo liberal de Estado

\footnotetext{
${ }^{37} \mathrm{O}$ modelo de aplicação de política ex ante diz respeito ao sentido preventivo das ações trabalhadas.

${ }^{38}$ No período de ditadura militar, sob a ordem de Segurança Nacional, as autoridades estatais buscam consolidar a Política de Bem-Estar do Menor, já referenciada no capitulo anterior como interesse inicial para a construção da atual Política de Atenção à criança e ao adolescente.
} 
até então vigente. No intuito de amortecer os desequilíbrios econômicos gerados pela crise do capital de 1929, bem como na perspectiva de combate aos desagravos sociais gerados pelo avanço da reestruturação produtiva de mercado e seu conseqüente desemprego estrutural, Keynes visualizou a necessidade de um novo Estado interventivo, capaz de conter o "ciclo do capital" através de mecanismos políticos (BOSCHETTI, 2006, p. 86). A partir destas medidas, o Plano Beveridge de $1943^{39}$ organizou projetos de caráter público nas áreas de Saúde, Previdência Social e Assistência Social em um conjunto denominado "Seguridade Social", originando, assim, uma rede de políticas essenciais, e assegurando meios do Estado garantir os considerados "mínimos sociais". No Brasil, as primeiras políticas de responsabilidade pública, desenvolvidas no momento de reforma do Estado moderno, definiam métodos de proteção social ligados à prática laboral, mediante contribuições dos assalariados através do "seguro social ${ }^{40 "}$ " Portanto, as formas de políticas sociais direcionadas aqueles incapacitados para o trabalho atendiam à lógica de inserir essa massa popular no mercado consumidor por mecanismos de combate ao "vício, vagabundagem e a imoralidade" (FALEIROS, 2008, p.12).

Em seu surgimento, o sistema de Seguridade Social foi construído por "negociações" entre os interesses da burguesia e do Estado, diante de uma sociedade moderna preocupada com o bem coletivo, nos quais havia a necessidade de dependência entre atores sociais para combater os problemas de âmbito social agravados pelas crises do sistema (MOTA, 2005, p. 40). As políticas sociais ${ }^{41}$ foram, então, idealizadas como

\footnotetext{
${ }^{39}$ Boschetti (2006) aponta três princípios do Plano Beveridge que estruturam o Estado-providência inglês (Welfare State), são eles: 1. A responsabilidade estatal exercida sobre os eixos da regulação da economia a fim de atingir o pleno emprego (conforme os ideais de Keynes), de prestação de serviços sociais universais, e serviços sociais pessoais; 2. Universalidade nos serviços sociais; 3. Implementação de uma rede de segurança de assistência social. No Brasil, o Plano Beveridge foi publicado em 1943, sendo que o termo "seguridade social" só é empregado com o reconhecimento na Constituição Federal de 88.

${ }^{40}$ No século XIX, o Estado alemão garantia o seguro social de saúde disponibilizado obrigatoriamente aos trabalhadores, proporcional à contribuição descontada pelo funcionário no tempo de serviço exercido. Este tipo de política social refere-se ao modelo bismarkiano de seguro social que funcionava sob uma óptica privada e focalizada a algumas categorias profissionais.

${ }^{41}$ Entende-se como políticas sociais estratégias de ação pública, planejadas e avaliadas, guiadas por uma racionalidade coletiva e não meramente individual, na qual Estado e sociedade desempenham papéis ativos. Toda a política social é considerada política pública, por se tratar de medidas estatais dirigidas a todos. No entanto, as políticas públicas podem não possuir caráter estatal direto, por abrangerem ações de âmbito privado, por instituições quem realizam atividades sociais com recursos públicos (BOSCHETTI, 2006). A utilização do conceito de políticas públicas no decorrer deste trabalho é considerada na análise
} 
iniciativa pública para intervir nos "efeitos negativos" externos (HOCHMAN et. al., 1998, p. 29) e solucioná-los em prol do bem-estar social. A saúde, entendida com "malpúblico"(HOCHMAN et. al., 1998, p. 28), era tratada como um problema emergente de interesse coletivo, pois pode afetar a sociedade como um todo quando não controlada. No Brasil, a Reforma urbano-sanitarista colocou em pauta a discussão de formas de combate às epidemias agravadas no século XIX, debate esse impulsionado pela elite temerosa com o contágio das doenças. Por meio de lutas e conquistas trabalhistas, nesse período a política de saúde era direcionada àqueles que estavam inseridos no mercado de trabalho (saúde previdenciária), através das "Caixas de Aposentadorias", pela Lei Eloi Chaves de 1923. A concentração e verticalização eram características da Reforma Sanitária nessa etapa em que o mundo atravessava os impactos da Primeira Guerra Mundial.

Em 1930, o enfrentamento às crises políticas e econômicas do capital foi marcado pela ampliação da autoridade estatal através da mudança de valor da saúde em prol da cidadania e civilização, vista como bem-estar coletivo. Os avanços de pesquisas e tecnologias voltados para a promoção da saúde influenciaram investimentos na infraestrutura urbana e rural, mobilizados pelo movimento sanitarista para combater às enfermidades entendidas como "atraso nacional" (HOCHMAN et. al., 1998). A inovada vertente de descentralização política, que delegava autonomia dos Estados e municípios, demonstra a reorganização dos arranjos sociais em democratizar a atuação nas políticas sociais emergentes no Brasil.

O investimento do Estado centrava-se em incentivar a participação dos pobres e desvalidos na lógica da produção, em prol do welfare economics, ou "bem-estar econômico" (FALEIROS, 2008, p.13). A ação social desempenhada pelo Serviço Social nesta época obedecia aos objetivos do Estado em controlar as classes afetadas pela pobreza por meio da execução de políticas de "higiene, educação e saúde", inclusive atendendo crianças com problemas de aprendizagem nas escolas, que passavam rapidamente pelas instituições de ensino, pois também eram aproveitadas como mão-deobra barata (MARTINELLI, 1989, p.110). No Brasil, até 1930 a pobreza era entendida

de redes, por entendê-la como perspectiva mais ampla, que inclusive engloba as políticas sociais estatais. Compreendida como o conjunto de ações públicas e privadas, a política pública é tudo aquilo que o governo faz e não faz, ou seja, medem-se os ganhos e perdas do que foi ou não foi investido pelo Estado. 
como uma disfunção individual tratada pelos aparelhos repressivos, não havia uma compreensão dos agravos da questão social. Como projeto de categoria inicialmente destinada a colaborar com ações de caridade desempenhadas pela Igreja Católica, o Serviço Social passa a assumir status e reconhecimento de profissão ao desenvolver funções necessárias de suporte ao Estado capitalista no controle de conflitos e tensões provocados por desajustes sociais, mantendo assim a ordem social (MARTINELLI, 1989). Desde então, o Serviço Social encontra-se envolvido na execução e formulação de políticas sociais, desempenhando um papel de representação e suporte ao Estado.

Considerando que as desigualdades sociais são produtos das complexas relações de trabalho ${ }^{42}$, marcadas por exploração e precarização, e não por culpa do indivíduo, a reestruturação de papel do Estado visou romper com a idéia de laissez-faire reproduzida pelo Estado liberal que se mostrava ineficaz frente aos problemas sociais (FALEIROS, 2008). O desempenho do Estado de Bem-Estar, em regular a situação de pobreza e miséria agravadas, "perdeu gradativamente a efetividade prática de sua ação" (BOSCHETTI, 2006, p. 90). Paralelamente aos avanços tecnológicos empregados pelo modelo fordista de produção e a crescente oferta de bens produzidos por tais investimentos, foi-se acumulando uma massa de reserva de trabalhadores excluídos do mercado de trabalho, o que significou um despencamento na taxa de lucros por conta da ausência de consumidores, considerando os índices de desemprego gerado. No período de 1970 a economia atravessava mais uma etapa de crise do capital no qual, diante da incapacidade das políticas sociais em conter os impactos sócio-econômicos agravados pela crise, a postura estatal é questionada pela corrente liberal.

Klaus Frey (2000) discute a prática das políticas públicas na relação entre o neoinstitucionalismo e os estilos políticos do Brasil, evidenciando na análise de determinada política, policy analysis, a ligação entre as instituições políticas (polity), o processo (politics) e seus conteúdos (policy), ou seja, a configuração dos programas de

\footnotetext{
${ }^{42}$ Destaca-se que a análise das relações de trabalho desencadeadas pelo modelo capitalista de produção é interpretada como conflituosa, conforme o olhar marxista, no qual o jogo de mercado favorece os detentores dos meios de produção pelos lucros acumulados, enquanto a classe trabalhadora é explorada em sua força de trabalho. As políticas sociais planejadas pelo Estado de Bem-Estar também possuíam o objetivo de controlar as massas e limitar as lutas trabalhistas encabeçadas pelos sindicatos, já que as ações estatais demonstravam atenção ás necessidades sociais.
} 
políticas públicas. Sob a articulação destas políticas, arranjada por uma rede de interdependência (policy networks) aderida pelos atores envolvidos, é que o Estado passa a atuar junto à população, mantendo uma relação de parceria com a sociedade.

Faleiros (2008) resgata em suas considerações a noção de necessidades proposta por Malinowski baseada na análise do culturalismo sociológico que prescreve as atividades sociais como meios de satisfação das necessidades humanas. Esta visão aparece como mais apropriada que a de Maslow, que define as necessidades apenas pela condição humana e psicológica do indivíduo biológico. Sendo assim, as instituições representam-se como "meios para satisfazer as necessidades dos sujeitos" (FALEIROS, 2008, p. 34). Na abordagem do autor, as políticas sociais são formas de promoção do consenso de Estado, pois por elas o Estado exerce interação e controle social ao atender as necessidades demandadas pela luta das classes subalternas bem como cumpre com as exigências do modelo produtivo.

A Ciência Política, como área do conhecimento dedicada a compreender tanto o sistema de organizações quanto as políticas públicas, entendidas como resultado das relações entre Estado e sociedade civil, deu origem às primeiras produções de análises direcionadas à interpretação do fenômeno de rede de políticas públicas (policy networks), surgido no cenário de processo político em meados dos anos 70, bem como fundado na Europa e nos Estados Unidos (KLIJN, 1998). Assim como esclarece Pereira (apud BOSCHETTI, 2008), a política pública apresenta-se como ramo de interesse da ciência política após a Segunda Guerra Mundial, durante o processo de instalação do Estado de Bem-Estar, considerando a necessidade de se entender a dinâmica das relações entre Estado e sociedade.

Como aporte de análise da realidade, a Ciência Política utiliza-se de enfoques coniventes com os momentos históricos e seus respectivos aspectos gerais, considerados elementos estruturantes do processo político. Estas dimensões foram classificadas de acordo com as perspectivas dos investigadores sobre os aspectos analisados, até evoluírem ao ponto de considerarem as políticas públicas como processo complexo. Portanto, sobre as políticas públicas revela-se a influência de atores variados, constituídas por processos marcados por conflito de interesses, nas quais existem decisões com inúmeras alternativas de solucionar problemas, sendo que o poder é dividido entre os múltiplos atores e as informações são caracterizadas como incertas 
devido à dinâmica de conflitos recorrentes (KLIJN, 1998). A sociologia colabora no sentido de discutir as relações entre a implementação de políticas e as organizações numa abordagem de rede inter-organizacional, espaço onde se constroem políticas. Surgida da vertente top-down, na qual as metas políticas são formuladas por um ator posicionado no topo hierárquico e direcionadas aos demais numa lógica vertical, a teoria inter-organizacional passa a igualar ao mesmo nível os diversos atores engajados no processo político, no intuito de solucionar os problemas pelo método bottom-uppers em função das informações transpassadas por redes de decisão e execução horizontais estabelecidas entre os sujeitos envolvidos.

A visão clássica racional, que compara as organizações como máquinas, sistematiza o conjunto de organizações em uma estrutura unitária, controladora e rígida, voltada a exercer comando eficiente na resolução dos problemas. Contudo, foram constatados limites nesse esquema organizativo, considerando a relação de dependência entre os subsistemas institucionais, que se comunicam através de acordos conforme suas necessidades. Neste diapasão, as Redes de Políticas Públicas são reconhecidas aqui como associações horizontais de organizações que compactuam formal ou informalmente com informações, recursos e interesses comuns, mantendo constante articulação por terem se estabelecido relações de interdependência estrutural (serviços organizacionais) e funcional (formulação e implementação de medidas), fundamentais ao funcionamento e ao alcance de objetivos (NOVAES, 2004).

Parson (apud FALEIROS, 2008) apresenta definição positivista ao indicar que o bem-estar do indivíduo encontra-se dividido por funções sociais a depender do estágio de socialização do mesmo, ou seja, de sua rede de relações sociais. Essa consideração torna-se oportuna para identificarmos que "as necessidades dependem da relação do indivíduo com o ambiente" (FALEIROS, 2008, p. 36). Os aparelhos ideológicos de Estado identificados por Althusser (apud FALEIROS, 2008), são essenciais para a consolidação e satisfação de necessidades a partir das diversas percepções de realidade construídas ao longo dos tempos, permitindo, assim, a (re)criação de novas necessidades conforme os interesses vigentes. Destaca-se, nesse debate, a evolução das características das políticas sociais, antes coniventes com a lógica repressiva e atualmente desenvolvidas por objetivos de socialização. Os movimentos sociais em defesa dos Direitos Humanos dirigiram estas transformações de diretrizes das políticas 
sociais de acordo com as reais necessidades daqueles que delas precisam. Os aparelhos ideológicos já mencionados não se apropriam das políticas sociais como instrumentos únicos das classes dominantes para subordinar as classes subalternas por meio da violência, mas atendem a compromissos variados em defesa dos trabalhadores e do mercado (FALEIROS, 2008).

A abordagem de análise de políticas públicas desenvolvida por Peter Hall, mais conhecida como a dos "três is", identifica as Idéias, os Interesses e as Instituições como peças presentes no processo político, dignas de conduzir uma análise condizente com a realidade adversa, considerando as funções dos atores sociais. Nessa perspectiva, as Redes de Políticas Públicas são representadas por esquemas de teias articuladas onde as pessoas e as entidades encontram-se submersos no jogo de poder e de interesses diversos. Ao mesmo tempo, são mobilizadas por objetivos convergentes que motivam o mantimento dos vínculos para uma ação mais eficaz e integral, mostrando-se como inovação adequada por preservar uma relação de solidariedade entre os membros integrantes da rede.

A formulação via rede não se baseia em comando e ordem, mas em negociação e intercâmbio. Este intercâmbio não significa, porém, que todos os atores se beneficiem igualmente da relação daí decorrente (SANTOS, 2005, p.04).

É válido reafirmar que a expansão das medidas de Estado, traduzidas por políticas sociais, tratam-se de concessões para sustentar o contexto social desfavorável, agravado por crises do capital. Faleiros (2008) atenta para a possibilidade de expansão e restrição das políticas sociais, flexíveis a correlações de forças e conjunturas. A intervenção do Estado depende tanto das exigências das classes sociais, no sentido de legitimação/coerção, quanto dos impactos gerados pelos movimentos de expansão e restrição das políticas sociais. As ações de manutenção da ordem social, portanto, surgem como formas de evitar tensões, e "a questão da delinquência transforma-se numa questão jurídica, o problema do menor numa questão de educação..." (FALEIROS, 2008, p.81). Dessa forma, o Estado assume a responsabilidade de prover melhores condições a todos, objetivando o desenvolvimento da cidadania por meio da articulação de rede de políticas sociais estruturadas. 
Considerada como fase específica, a juventude ${ }^{43}$ é colocada em meio ao conflito entre adaptação e impossibilidade de incorporação de responsabilidades, que são demandadas à categoria para assumirem um determinado papel social, basicamente rumo à preparação para o mundo adulto. Os agravantes em torno desse fato se devem ao isolamento dos jovens como membros atuantes da sociedade, por barreiras existentes como: a) a segregação espacial; b) a separação dos espaços públicos de sociabilidade informal; c) a segmentação dos serviços públicos básicos (2000, p. 19). Como marcos inerentes à condição juvenil se destacam:

\begin{tabular}{|l|l|}
\hline \multicolumn{1}{|c|}{ ASPECTOS } & \multicolumn{1}{c|}{ CARACTERÍSTICAS } \\
\hline 1) Meta & Obtenção da personalidade adulta \\
\hline 2) Trajetória & Emancipação e autonomia \\
\hline 3) Problema central & Construção de uma identidade própria \\
\hline 4) Marco básico & Relações intergeracionais. \\
\hline
\end{tabular}

FONTE: CEPAL, 2000. Esboço da autora.

No entanto, dentre os diferentes aspectos que identificam o perfil do jovem, a maior interferência que impede o exercício da cidadania deste sujeito diz respeito às limitações exteriores, inerentes às respostas setoriais desarticuladas. Reconhecendo a "participação" como palavra-chave ligada à personalidade do adolescente em sua expressão, a sociedade manipula a imagem do jovem e cria uma "participação material" limitada do mesmo, aproveitando do simbolismo consumista em torno de sua condição, o que gera situações de marginalidade e exclusão social daqueles jovens que não se enquadram nos padrões sociais de consumo (CEPAL, 2000).

\footnotetext{
${ }^{43} \mathrm{O}$ livro organizado pela CEPAL (2000) se refere à juventude latino-americana considerando como o grupo de sujeitos que vivenciam a "etapa de aquisição de valores e ações que o mundo adulto requer", ou seja, "os jovens". Contudo, não significa que estes indivíduos estejam isentos de obrigações ou não sofram influências de interesses estruturais, como citado: "suspensão temporal de obrigações" (2000, p. 14). O critério de idade para dividir as fases evolutivas da vida humana é definido por convenção e consenso público, levando em conta os aspectos biológicos e psicológicos que distinguem crianças e adolescentes, conforme a realidade estrutural e social de cada cultura. A juventude é, então, entendida como período que intercala a maturidade fisiológica e a maturidade social da pessoa.
} 
A centralidade das políticas públicas focalizadas, segmentadas em aspectos particulares de necessidades do adolescente e sem perspectiva de articulação, interfere na abrangência do atendimento. Visto que os jovens são apenas receptores passivos dos serviços públicos, as políticas públicas básicas atingem aos jovens integrados nas instituições e serviços disponíveis, enquanto os jovens excluídos são objetos de ações de controle social, por representarem perigo.

Las políticas públicas destinadas a la juventud, han podido enfrentar estos desafios solo parcialmente, y a través de enfoques limitados. Para poder obtener mejores impactos em La población joven, se requiere um enfoque generacional que, al igual que El enfoque de gênero, impregne todas y cada uma de lãs iniciativas programáticas (CEPAL, 2000, p. 23).

Dentre as dificuldades de integração social enfrentadas pelos adolescentes encontram-se a ausência de articulação interinstitucional entre as dimensões de políticas públicas existentes. A dificuldade de acesso e a distância entre os atendimentos nos âmbitos da educação, trabalho e saúde de jovens, são empecilhos inclusive para o combate da recente ênfase nas situações de violência juvenil. Identificado tal entrave, sugerem-se prioridades de ação governamentais a serem investidas pelo conjunto articulado de políticas, relevadas na análise deste trabalho como eixos fundamentais inclusive na composição da política de atendimento voltada ao adolescente autor de ato infracional:

1. desplegar um esfuerzo em educación y salud, como clave para la formación de capital humano;

2. priorizar la ingregración social de los jóvenes excluídos como la principal política sustantiva del futuro;

3. considerar la inserción laboral de los jóvenes como clave para su ingración social;

4. otorgar una gran prioridad a la prevención de la violência juvenil, como clave de la convivência pacífica tan anhelada por todos los latinosamericanos y caribeños;

5. fomentar uma amplia y profunda participacion juvenil, como um factor relevante em relación com el fortalecimento democrático de nuestros países; $\mathrm{y}$

6. potenciar el voluntariado juvenil, como um gran eje articulador de los objetivos antes mencionados (CEPAL, 2000, p. 46). 


\subsection{Constituição Federal de 1988 e as Políticas Sociais}

A Assistência Social é um exemplo de política que surgiu como mediação alternativa do Estado quando o mesmo não consegue introduzir a parcela "pobre" da população no mercado de trabalho, portanto tem como alvo aqueles privados de seus direitos sociais por motivos que envolvem sua realidade precária, medida por seu poder aquisitivo de consumo, ou seja, pela renda. No entanto, vale ressaltar que o contexto atual retira a centralidade do trabalho como determinante para definir as condições de pobreza, pois a categoria trabalho ganhou um significado subjetivo diante da fragmentação trabalhista observada no setor de serviços, formado por terceirizações e atividades informais. Segundo análise de Valladares (1991, apud LAVINAS, 2003, p. 44) “os pobres não são mais descritos como vadios ou tampouco marginais, mas trabalhadores expropriados dos frutos do desenvolvimento econômico e do bem-estar social". Apesar disso, a "ideologia da normalidade" se refere à cultura vinculada à regra de que "trabalho é o critério da vida normal para viver-bem" (FALEIROS, 2008, p. 63), reproduzida até os dias atuais.

Os estereótipos construídos em torno deste ideal perduram e consideram os excluídos do mercado de trabalho como "fracassados", sendo que os próprios são, ainda, culpabilizados por sua condição, victim blaming (FALEIROS, 2008, p.63). Deste modo, a política sócio-assistencial é considerada contraditória na medida em que pode atender tanto às necessidades sociais quanto aos interesses da rentabilidade econômica do capital, ao passo que proporciona a inclusão da parcela beneficiária da população, antes excluída das relações sócio-econômicas, no jogo do mercado consumidor. Além disso, exerce certo controle contra revoltas sociais ao assistir financeiramente as classes menos abastadas que antes não contribuíam consideravelmente com o país através dos lucros do trabalho (PEREIRA, 2008).

Foi com a institucionalização da Constituição Federal de 1988 que tanto a Assistência Social como as demais políticas foram reconhecidas em seu caráter público, devendo ser garantidas como "direito do cidadão e dever do Estado" (LIMA, 1998, p. 99). No entanto, apesar dos princípios legais de descentralização, universalização e participação social $^{44}$, a repercussão da política de Assistência Social no Brasil carrega

\footnotetext{
${ }^{44}$ Os princípios citados foram definidos pela Lei Orgânica de Assistência Social, nº 8.742 de 1993, que prevê a interação da Assistência Social com demais políticas setoriais.
} 
resquícios característicos de seu processo de consolidação, reproduzindo-se na concepção da sociedade o ideal/estereótipo de "favor" associado ao repasse de renda governamental às famílias necessitadas, considerado este o principal meio que configura hoje tal política como strito sensu, ou seja, imediatista e assistencialista em sua aplicação.

No Brasil, a Legião Brasileira de Assistência (LBA), criada em 1946, até 1995 foi a instituição pioneira a implementar ações assistenciais com bases na caridade pontual, resquícios do que viria a se consolidar como política de Assistência Social. A LBA surgiu como obra administrada pela primeira dama do governo de Getúlio Vargas, e promovia uma prática assistencialista de ajuda aos menos afortunados. Diante deste retrospecto, há um desafio posto de rompimento a esta lógica caritativa no processo de construção da política de Assistência Social, de emancipação social concreta voltada àqueles que necessitam, ou seja, às vítimas da desigualdade social gerada pelo sistema capitalista. "Desde sua origem, a assistência à infância foi prioridade na Instituição" (BARBOSA, 2000). Em 1969, a LBA é transformada em fundação vinculada ao Ministério do Trabalho e Previdência Social, tendo sua estrutura ampliada e passando a contar com novos projetos e programas. A ditadura militar cria, sob o comando de Geisel, em $1^{\circ}$ de Maio de 1974, o Ministério da Previdência e Assistência Social MPAS - que contém na sua estrutura uma Secretaria de Assistência Social que é a principal formuladora de políticas de enfrentamento à pobreza, sob a ênfase de tratamento inovador nessa área, fugindo do caráter assistencialista e de simples complementação da previdência.

A Política de Assistência Social toma uma dimensão muito grande perdendo a característica simplificada de filantropia, porém não deixa de ser focalizada, restritiva e descontinua. O Estado oscila entre a repressão imposta pela ditadura e a assistência oferecida para o controle dos problemas sociais, apoiado nas instituições sociais. Nesta época, os movimentos sociais tiveram uma participação singular na luta pela regulação da Assistência Social como direito. As Associações Nacionais dos Servidores da LBA ASSELBAS e ANASSELBAS - se articulam gerando debates, documentos, posicionamentos e proposições para a efetiva inserção da Assistência Social na Constituição Federal como política social, direito do cidadão e dever do Estado. Em meio a essa pressão forte exercida pelos movimentos sociais organizados e articulados 
por uma causa única, as políticas sociais encontram campo fértil para desenvolverem-se e auxiliarem a efetivação dos direitos sociais na Constituição de 1988.

A Política Nacional de Assistência Social (PNAS) hoje consolidada no Brasil apóia-se no amparo legislativo da Lei Orgânica de Assistência Social (LOAS), de $\mathrm{n}^{\circ}$ 8.742/1993, que corporifica uma política pública regida por diretrizes de descentralização dos serviços e de universalidade da cobertura do atendimento por níveis de complexidade. Sendo assim, a Assistência Social faz parte do tripé das políticas básicas de Seguridade Social brasileira, juntamente com a Saúde e a Previdência.

Art. 194. A seguridade social compreende um conjunto integrado de ações de iniciativa dos Poderes Públicos e da sociedade, destinadas a assegurar os direitos relativos à saúde, à previdência e à assistência social (Disponível em http://www.planalto.gov.br/ccivil_03/constituicao/constitui\%C3\%A 7ao.htm).

Faz-se importante ressaltar a incorporação dessa lei ao princípio de incentivo à participação dos "diversos setores envolvidos na área", sem deixar de frisar "a primazia da responsabilidade do Estado na condução da política de assistência social em cada esfera de governo" (BRASIL - LOAS, 1993, p.10). A transferência compartilhada de funções específicas entre os Estados, Municípios e Distrito Federal, é preconizada na Constituição Federal de 1998 em seu artigo 204, incisos I e II. A LOAS, em seu Artigo $5^{\circ}$, reafirma a necessidade da descentralização em suas diretrizes de organização, quando resgata o fundamental desenvolvimento da ação social de maneira articulada, numa coordenação de parceria entre essas três esferas de governo, inclusive com a participação da sociedade civil. A PNAS já alerta a necessidade de constituição de uma rede de serviços correspondentes à Assistência Social, como forma de garantir "maior eficiência, eficácia e efetividade em sua atuação específica e na atuação intersetorial" (BRASIL, PNAS, 2004, p.06) - em obediência aos artigos $2^{\circ}$ e $3^{\circ}$ da LOAS de responsabilidade direta da Assistência Social -, e da co-responsabilidade das demais políticas complementares.

A Constituição Federal da República do Brasil, promulgada em 1988, institucionalizou a Assistência Social e confirmou a responsabilização do Estado em desenvolver articuladamente as políticas de Seguridade Social garantindo acesso a 
população, principalmente à criança e ao adolescente, tidos como alvo prioritário de proteção. O artigo 227 da Carta Magna institui como

Dever da família, da sociedade e do Estado assegurar à criança e ao adolescente, com absoluta prioridade, o direito à vida, à saúde, à alimentação, à educação, ao lazer, à profissionalização, à cultura, à dignidade, ao respeito, à liberdade e à convivência familiar e comunitária, além de colocá-los a salvo de toda forma de negligência, discriminação, exploração, violência, crueldade e opressão.

Logo em seguida, na ordem, o artigo 228 defende como "penalmente inimputáveis os menores de dezoito anos, sujeitos às normas da legislação especial”. As políticas específicas à juventude se devem, também, à ampliação dos índices de violência envolvendo essa camada ainda em situação peculiar de desenvolvimento, resultados da contradição entre o período de crescimento econômico paralelamente ao agravamento da pobreza e exclusão social ocorrida desde o Brasil Império. No período pós $\mathrm{CF} / 88$, evidenciam-se fortes inspirações neoliberais nas ações do Estado no campo social. As políticas sociais assumem características seletivas e compensatórias. Deflagra-se um movimento de desresponsabilização do Estado na gestão das necessidades e demandas dos cidadãos. O Estado passa a transferir as suas responsabilidades para as organizações da sociedade civil sem fins lucrativos e para o mercado. Com o advento da modernidade, os padrões de convívio impostos pela urbanização no Brasil, o aumento da pauperização nas cidades e, por consequiência, o acirramento da violência e criminalidade implicaram na desordem e envolvimento do "menor" nesta onda de delitos, onde a "questão social era questão de polícia", ou seja, um problema social a ser combatido (DEL PRIORE; SANTOS, 2006, p. 220).

Diante das problemáticas geradas por um sistema que intensifica as desigualdades sociais, o Estado teve de se posicionar frente à necessidade de controle aos delitos que apavoravam as elites, a fim de manter sua legitimidade. Observado o regaste histórico, as medidas jurídicas do país se manifestavam pelos preceitos do Código Penal do Império, instituído em 1831, que julgava adultos e crianças sem distinção (BRASIL - LOAS, 1998). Os "menores" condenados ao rigor dessa lei, ainda considerados pessoas sem personalidade definida, eram recolhidos à Casa de Correção, instituições fechadas de contenção que atuavam de maneira punitiva pelo método da Pedagogia do Trabalho (DEL PRIORE, 2006). Mione (2007) explica a "inexistência da cidadania dos tempos pré-republicanos" (MIONE, 2007, p. 26) ao referir-se a 
invisibilidade perversa e a visibilidade discriminatória referenciadas ao adolescente inserido no cenário de pobreza e violência urbana, considerados paradoxalmente vulneráveis e perigosos.

Concomitantemente às discussões internacionais que incluíam na agenda de objetivos dos Estados envolvidos a ampliação da cidadania e dos direitos humanos, o Código de Menores de 1927 começa a estabelecer distinção entre a aplicabilidade da lei criminal de crianças à de adultos, culpabilizando e punindo, assim, o menor por sua conduta desviante através do modelo correcional-repressivo de atendimento, reproduzido pelo Serviço de Assistência ao Menor (SAM), que em 1964 transformou-se em Fundação Nacional do Bem-Estar do Menor (FUNABEM). Paralelo a estas renovações, na medida em que o debate entre países se prolongava acerca dos Direitos Humanos, a construção de uma política substanciada voltada a infância e juventude era intensamente elaborada.

Nesta perspectiva, em 1979 foi criado o novo Código de Menores que atualizou a Política Nacional de Bem-Estar do Menor (PNBEM) e considerava a situação do menor como irregular. O resgate social desses indivíduos dependia de um atendimento educativo que, pela primeira vez, deveria ser desenvolvido dentro das instituições de reclusão para prepará-los à vida em sociedade. Contudo, este Código não alterou sobremaneira a política em questão, ao contrário, perpetuaram as práticas punitivas nos regime de internatos. A não efetivação desta política e o agravamento da crise dos anos 80 fomentaram o surgimento dos movimentos que desaguaram no movimento prócrianças e adolescentes durante a constituinte e na inclusão do artigo 227 na CF.

Os movimentos sociais, como destaque o Movimento Nacional dos Meninos e Meninas de Rua - MNMMR - de 1985, impulsionaram a construção de leis nacionais que viessem amparar os direitos das crianças e adolescentes e mudar a qualidade das políticas executadas na época, antes assistencialistas e repressivas. O ECA, instituído pela lei $n^{\circ} 8.069 / 90$, rompe com os princípios dos antigos Códigos de Menores, destinados aos "menores carentes ou em situação irregular", e propõe tratamento diferenciado à criança e ao adolescente na perspectiva de prepará-los para atingirem o mundo adulto de forma plena (RODRIGUES, 2008). Para isso, é assegurada que esta fase da vida seja contemplada por acesso a políticas através de uma série de medidas 
pautadas no contexto da "doutrina jurídica da Proteção Integral" desses sujeitos, também, possuidores de direitos (FILHO, 1997).

Granovetter (1978; apud MARTES, 2006) traça um modelo de políticas organizadas em redes interpessoais, podendo ser adaptado à realidade e necessidades do jovem. Os adolescentes encontram-se inseridos em um círculo social formado por laços fortes (famílias, amigos), fracos (pessoas conhecidas) e inexistentes (quando não há investimento). A tese de Granovetter indica a importância de conexão entre esses tipos de laços para a constituição de redes comuns de relacionamento e informações. A ligação entre os atores sociais da rede não deve ser redundante, depende das variáveis de tempo, intensidade emocional, confiança mútua e reciprocidade de serviços prestados, que devem ser almejadas para manter a eficácia e qualidade entre os contatos, bem como o engajamento das atividades da estrutura de redes. Essas considerações são essenciais para compreender os adolescentes como sujeitos sociais, reconhecendo que seu desenvolvimento emocional/psicológico, dependente de sua realidade adversa. As situações de violência e privação de direitos nas quais os mesmos encontram-se expostos podem implicar em respostas expressas por sua conduta, seu modo de agir motivado por seus valores.

No âmbito do Distrito Federal, as diretrizes de ações para a política de atenção a infância e adolescência também são consideradas por critérios consolidados na PNAS e objetivados pelo Sistema Único de Assistência Social (SUAS), e revelam a organização do sistema de proteção com as seguintes bases:

Descentralização do atendimento;

Valorização dos vínculos familiares e comunitários;

Atendimento prioritário em situações de risco, definidas em lei; Participação da sociedade na formulação de políticas e programas, bem como no acompanhamento de sua execução, por meio de organizações representativas. (LODF, Capitulo VII- ART. 268, 1993)

O SUAS é resultado da união de todo o Estado - União, Estados Federal e Municípios - que busca um trabalho coletivo para consolidar e ampliar parcerias, maximizando o impacto dos recursos invertidos nas políticas sociais. É um sistema de participação e organização em rede de serviços e ações de diferentes complexidades e benefícios, que direciona atenção central à família. A PNAS aponta como base de atuação da Assistência Social a "visão social" ampla, composta por três vertentes de 
proteção social a serem investigadas e trabalhadas, são elas: às pessoas, às suas circunstâncias, além do núcleo de apoio principal presente entre elas, isto é, a família. A aproximação do cotidiano aparece como meio fundamental de realização dos objetivos almejados dentro das esferas sociais citadas. Dentre os grupos considerados vulneráveis atendidos pela política de Assistência Social encontram-se as crianças e os adolescentes, contemplados por serviços e programas de proteção de baixa, média e alta complexidade, a depender do seu contexto de risco. Na Proteção Social Especial de média complexidade oferecem-se "atendimentos às famílias e indivíduos com seus direitos violados, mas cujos vínculos familiares e comunitários não foram rompidos" (BRASIL - PNAS, 2004, p. 22). O acompanhamento destes casos demanda maior suporte técnico e de recursos, dentre eles estão:

1) Serviço de orientação e apoio sócio-familiar;

2) Plantão Social;

3) Abordagem de Rua;

4) Cuidado no Domicílio;

5) Serviço de Habilitação e Reabilitação na comunidade das pessoas com deficiência;

6) Medidas sócio-educativas em meio-aberto (PSC - Prestação de Serviços à Comunidade e LA - Liberdade Assistida).

Já na Proteção Básica Assistencial, voltada à infância e adolescência, são investidos apoio e financiamento aos serviços de proteção a estes indivíduos vulnerabilizados pela pobreza, buscando assegurar o desenvolvimento integral da criança, bem como valorizando a convivência social e familiar. Um dos objetivos gerais do Plano Nacional de Promoção, Proteção e Defesa dos Direitos das Crianças e Adolescentes à Convivência Familiar e Comunitária (2004) diz respeito ao aspecto de apoio psicossocial necessário à manutenção dos mesmos em seu ambiente familiar e comunitário, considerando as condições e características de sua família e rede social. Pode-se confirmar que esta produção teve seus fundamentos espelhados nos princípios do ECA (BRASIL, 2005, Do Direito à Convivência Familiar e Comunitária, capítulo III), inspirado pela necessidade de se ampliar e trazer mais elementos contributivos à 
defesa dos direitos da criança e do adolescente do Brasil. Desta forma, entende-se que o ECA é um material que define princípios revolucionários de guia a outros produtos dedicados à garantia dos direitos à infância e à juventude, posto que o desafio de se efetivar uma política completa voltada aos diversos interesses da criança e do adolescente depende de estrutura política organizada, com a colaboração e articulação do SGD.

O espaço físico de execução dos serviços de Proteção Especial da Assistência Social seria o Centro de Referência Especializado da Assistência Social (CREAS), por meio de estratégias de ação respaldadas nas políticas públicas que garantam orientação e convívio sócio-familiar e comunitário à criança e ao adolescente (BRASIL, 2004). A Assistência Social incorpora em seus objetivos a atenção aos adolescentes em conflito com a lei, "violados em razão de sua conduta" (BRASIL, 2005, p.28), mais especificamente àqueles submetidos ao cumprimento de Medidas Socioeducativas em meio aberto. Entretanto, no Distrito Federal há uma discordância em relação à aplicabilidade destas Medidas Socioeducativas pelos CREAS, pois "embora previstas na Política Nacional de Assistência Social, saíram do âmbito do órgão gestor da política de Assistência Social nesse território e foram transferidas para a recém-criada Secretaria de Estado de Justiça, Direitos Humanos Cidadania do Distrito Federal (SEJUSDHC)" (CINTRA, 2007, p.56).

Apesar da Política de Assistência Social ter se interessado em contemplar o atendimento ao adolescente autor de ato infracional, na prática a responsabilidade de execução das Medidas Socioeducativas de PSC e LA no Distrito Federal foi assumida pela $1^{\text {a }}$ Vara da Infância e da Juventude do Tribunal de Justiça do Distrito Federal e Territórios (VIJ/TJDFT), instituição do Poder Judiciário, através da Seção de Medidas Socioeducativas (SEMSE). Esse fato caracteriza-se como problema estrutural de organização do sistema de atenção a este adolescente, visto que a execução das Medidas Socioeducativas deveria ser efetivada por órgãos do Poder Executivo. Tal discussão diz respeito, ainda, a qual instituição e política estariam mais aptas a executar as Medidas em questão, seja a de Assistência Social - através da Secretaria de Desenvolvimento Social e Transferência de Renda (SEDEST) -, como sugere a PNAS, ou que seja a de Direitos Humanos e Cidadania - pela SEJUS. 


\subsection{ECA e o Ato Infracional: Punição ou Socioeducação?}

A reestruturação da política de atenção ao adolescente autor de ato infracional ${ }^{45}$, reconhecida e conferida pelo ECA, acompanhou os avanços legais que romperam com as antigas medidas de punição e coerção traçadas nos Códigos de Menores de 1929 e 1979 para fundar medidas de responsabilização do adolescente, levando em conta sua condição de sujeito em desenvolvimento detentor de direitos e deveres. A concepção de cidadania defendida pelo ECA é trabalhada nas medidas de cunho Socioeducativo aplicadas aos adolescentes que cometeram ato infracional ${ }^{46}$. A conduta do adolescente aparece como razão a ser repercutida socialmente, portanto, digna de intervenção por intermédio de medidas de proteção dos mesmos, destacando-se o direito de ser ouvido pelas autoridades judiciais competentes no processo, ao passo que se enfrenta a criminalidade juvenil (FILHO, 1997).

Segundo as Regras de Beijing (1988), “infração é todo comportamento (ação ou omissão) penalizado com a lei, de acordo com o respectivo sistema jurídico”. Estas Regras Mínimas, instituídas por discussões travadas pelo conselho de Estados membros da Organizações das Nações Unidas (ONU), já demandavam posicionamento a nível nacional da administração dos países membros para organizarem seus sistemas jurídicos referentes aos assuntos da Infância e Juventude. O cuidado de consolidar parâmetros internacionais à responsabilização penal foi considerado ao estabelecer-se que "não deverá fixar-se numa idade demasiado precoce, levando-se em conta as circunstâncias que acompanham a maturidade emocional, mental e intelectual" do jovem infrator de cada localidade (BRASIL - CF, 1988). Importante salientar o movimento simultâneo de instauração dessa publicação, divulgada pela Fundação Nacional de Bem-Estar do Menor - FUNABEM -, comparativamente à promulgação da "Constituição Cidadã de 1988", traçando objetivos de ampliação da Política de Atenção à Criança e ao Adolescente que serviu de rascunho à consolidação do que viria a ser especificado, em seguida, no ECA. Ao exemplo disso, a contribuição da Convenção Internacional dos

\footnotetext{
${ }^{45}$ Considera-se a distinção terminológica entre "autor de ato infracional" e "adolescente infrator", sendo a primeira a forma mais legítima e aceitável por determinar o significado da situação infracional momentânea do adolescente, enquanto a última denota um sentindo característico ou permanente (VERONESE, et al; 2001, p. 35).

${ }^{46}$ O Artigo 103 do ECA considera ato infracional como conduta equivalente ao crime ou contravenção penal.
} 
Direitos da Criança, de 1989, inaugurou a Doutrina de Proteção Integral propagada nas leis e metas governamentais de defesa à criança e ao adolescente, segundo sua condição especial de desenvolvimento (VERONESE et. al., 2001).

Os documentos construídos em períodos anteriores ao ECA, que tiveram importante influência no debate colaborativo quanto à elaboração do mesmo, como exemplo de Planos Nacionais, Convenções Internacionais e Nacionais, Declarações, entre outros, foram frutos de convergências entre os países participantes que visualizaram a situação histórica de penúria e exclusão sofrida por crianças e adolescentes, antes considerados objetos a serem controlados por conta da cultura da violência e do medo social ligado aos "jovens criminosos" (MIONE, 2007). A ausência de políticas públicas que atendessem às necessidades específicas da infância e adolescência foi questão prática central a ser reparada e investida pelos países membros das discussões travadas em prol da política direcionada a tal público.

O Estado brasileiro atuava no sentido de punir as falhas individuais e, para isso, impunha política de retenção como estratégia de controle dos então "menores criminosos", ainda vistos como "patologia social" (FILHO, 1997, p.115). No entanto, na medida em que a violência juvenil começa a ser interpretada como fenômeno intrínseco ao meio social do adolescente, os países do mundo globalizado buscam alternativas concretas de preservação da integridade do adolescente através de políticas de prevenção e responsabilização do adolescente a quem se atribui autoria de ato infracional. Essa mudança de paradigma só foi possível por nova postura assumida pelo Estado neoliberal, ao desenvolver políticas públicas de atenção ao adolescente, em resposta às exigências da sociedade e dos movimentos de luta, compartilhando essa responsabilidade com a sociedade. A Constituição Federal de 88 resgatou as considerações anteriores, defendidas por regulamentos internacionais e nacionais direcionados à responsabilização jurídica do adolescente em situação infracional, e fundou como premissa:

$\S 3^{\circ}$ - O direito a proteção especial abrangerá os seguintes aspectos:

IV - garantia de pleno e formal conhecimento da atribuição de ato infracional, igualdade na relação processual e defesa técnica por profissional habilitado, segundo dispuser a legislação tutelar específica; 
V - obediência aos princípios de brevidade, excepcionalidade e respeito à condição peculiar de pessoa em desenvolvimento, quando da aplicação de qualquer medida privativa da liberdade;

Nesse sentido, a abordagem de redes de políticas (policy networks) vem sendo exigida como estratégia essencial e meio eficiente de se garantir a plenitude do adolescente, inclusive na operacionalização das Medidas Socioeducativas trazidas pelo ECA (Art. 112; BRASIL - ECA, 2005, p. 30). A aplicação destas Medidas se dá preferencialmente àquelas definidas em meio aberto $^{47} \mathrm{e}$ em caráter excepcional sob meio de privação de liberdade, a definir conforme fatores que caracterizam o ato infracional julgados em paralelo aos Códigos Civil e Penal ${ }^{48}$. Sobre este ponto, existe polêmica quanto à opinião pública formada, principalmente pela mídia, em relação ao princípio da inimputabilidade garantida à criança e ao adolescente, tendo em vista a associação entre segurança e prisão que a sociedade legitima. Apesar da proteção garantida legalmente ao adolescente autor de ato infracional, esta questão envolve a necessidade de mudança cultural tanto em relação aos julgamentos isolados que se tem do sujeito adolescente quanto a respeito da proposta Socioeducativa de responsabilização do mesmo, inclusive em meio aberto, com vistas a ampliar o olhar da situação infracional considerada principalmente como um reflexo social e não somente pessoal.

Segundo o mapeamento nacional da situação do atendimento dos adolescentes em cumprimento de Medidas Socioeducativas (2006), a parcela de adolescentes submetidos a cumprimento de medida em privação de liberdade (15.426 adolescentes) é pequeno em relação ao total de adolescentes (de idade entre 12 e 21 anos) do Brasil, cerca de 33 milhões. A proporção calculada é de que para cada 10.000 adolescentes brasileiros existem menos de três adolescentes cumprindo medida em meio fechado. No entanto, dados do Levantamento Nacional do Atendimento Sócio-educativo ao Adolescente em Conflito com a Lei (2006) revelam que houve "um aumento expressivo na taxa de

\footnotetext{
${ }^{47}$ Prestação de Serviços á Comunidade e Liberdade Assistida (Art. 112, II e III; ECA, 2005, p. 31).

${ }^{48}$ Os direitos Penal e Civil englobam os adolescentes como sujeitos sociais, no entanto não respondem diretamente às questões ligadas a eles. As definições de crimes e contravenções penais são identificadas pelo Código Penal e o Código Civil reconhece a maioridade dos 18 anos, porém a responsabilização do adolescente cabe à aplicação de Medidas Socioeducativas elencadas no ECA, uma vez que reconhecida as distinções da criança e do adolescente em relação aos adultos. No caso da apuração do ato infracional e aplicação da Medida Socioeducativa "as circunstâncias delimitam a gravidade do ato infracional" (VERONESE, 2001, p. 46).
} 
crescimento da lotação do meio fechado no país entre os anos de 2002-2006, correspondendo a 28\%", inclusive apontando o Distrito Federal entre as unidades federativas que mais internam adolescentes, proporcionalmente à sua população jovem (BRASIL, 2006, p. 03). O custo variável mensal de um adolescente privado de liberdade está em torno de $\mathrm{R} \$$ 1.898,00 e R \$ 7.426,00 (UNICEF, “Custos e Qualidade das Medidas Sócio-educativas” - estudo n4).

De 2006 para 2008 houve gradual redução da taxa de adolescentes sob regime de internação. Esta tendência significa a aplicação primordial de medidas em meio aberto prevista pelo Sistema Nacional de Atendimento Socioeducativo - SINASE - tarefa que depende de investimentos que ampliem a municipalização dos programas de Liberdade Assistida - LA - e de Prestação de Serviços à Comunidade - PSC - (OLIVETO, 2009). Este trabalho concentra-se em analisar a Medida Socioeducativa de PSC por considerála espaço propício de promover a emancipação do adolescente autor de ato infracional, considerando a proposta Socioeducativa de responsabilização do mesmo pela execução de serviços intra-institucionais e a participação em atividades de cunho educativo, bem como a proximidade do adolescente com a comunidade em questão. No entanto, entende-se que a aplicação da PSC e o efetivo impacto social reproduzido na realidade do adolescente submetido ao cumprimento desta Medida compreendem a contribuição de aparelhos representativos das diversas políticas públicas, capazes de fornecer suporte ao atendimento das demais necessidades deste "jovem violentado" em sua integralidade de cidadão.

Portanto, apesar de em razão da conduta do adolescente serem indicadas Medidas Protetivas (Art. 101, I-VIII, ECA, 2005, p. 29) cumuladas com as Medidas Socioeducativas, como referenciado no Artigo 113 do $\mathrm{ECA}^{49}$, a utilização de serviços e programas integrantes da Rede de Políticas Públicas se torna relevante na aplicação das Medidas Socioeducativas por corresponderem ao objetivo de atenderem "as necessidades pedagógicas, preferindo-se a aquelas que visem ao fortalecimento dos vínculos familiares e comunitários" (Art. 100, BRASIL, ECA - 2005, p.29). A diferença definida em capítulos no ECA entre as Medidas Protetivas e as Medidas

\footnotetext{
49 Art. 113. Aplica-se a este Capítulo o disposto nos Arts. 99 e 100. Sendo que o Art. 99 define a possibilidade da aplicação de Medidas Protetivas isoladas ou cumulativamente. Vale destacar que cabe ao Conselho Tutelar a aplicação e acompanhamento das Medidas Protetivas.
} 
Socioeducativas distanciam a articulação prática das duas Medidas, que funcionam de maneira independente. Na Medida de LA ${ }^{50}$ é imposta a aplicação paralela com serviços de proteção disponíveis na rede de políticas públicas conforme as necessidades sociais dos adolescentes autores de ato infracional. Esta articulação entre as Medidas Socioeducativas e as Medidas Protetivas é entendida como imprescindível no atendimento de adolescentes envolvidos em situação infracional, considerando que o objetivo Socioeducativo vai além da responsabilização deste adolescente que também merece ser garantido em sua integralidade por necessitar de intervenção social que venha transformar sua realidade conflituosa.

Questiona-se aqui a importância do trabalho em rede de políticas públicas na aplicação da PSC, tendo em vista a oportunidade que o meio aberto proporciona do adolescente interagir, em seu cumprimento, com a comunidade através da execução de serviços gratuitos em instituições diversas. A proximidade comunitária, viabilizada pelo vínculo social estabelecido nos estabelecimentos integrantes da própria rede de políticas públicas, infunde a responsabilização do adolescente por meio do aprendizado conferido pela proposta Socioeducativa. Contudo, a simples prestação de serviços gratuitos nos locais indicados requer um diferencial que fuja do viés punitivo e contemple os anseios pelos meios possíveis dos adolescentes atuarem ativamente como cidadãos.

\footnotetext{
50 À Liberdade Assistida, por ser aplicada quando há necessidade de "acompanhar, auxiliar e orientar" (BRASIL - ECA, 2005, p. 32) diretamente o adolescente autor de ato infracional, é indicado um trabalho substancial junto à rede de políticas públicas voltada a este adolescente, considerada como o conjunto de serviços e programas equivalentes às Medidas Protetivas indicadas no ECA.
} 


\section{CAPÍtulo IV - SINASE E A PRESTAÇÃo DE SERVIÇOS À COMUNIDADE}

O Sistema Nacional de Atendimento Socioeducativo- SINASE (2006) - é a política pública central que engloba a Rede de Atenção ao adolescente autor de ato infracional, elaborado por atores sociais comprometidos em tornar efetiva a Doutrina de Proteção Integral direcionada a este adolescente por meio de eixos de estratégias específicas que permitem operacionalizar as Medidas Socioeducativas em consonância com os princípios traçados no ECA. O SINASE confirma a importância da intersetorialidade entre as diversas políticas públicas no processo de (re)inserção social do adolescente autor de ato infracional, confirmando a necessidade de se firmar um "pacto social" entre os envolvidos (BRASIL, 2006, p.12). O esquema abaixo ilustra a rede de articulação que deve estar em constante comunicação:

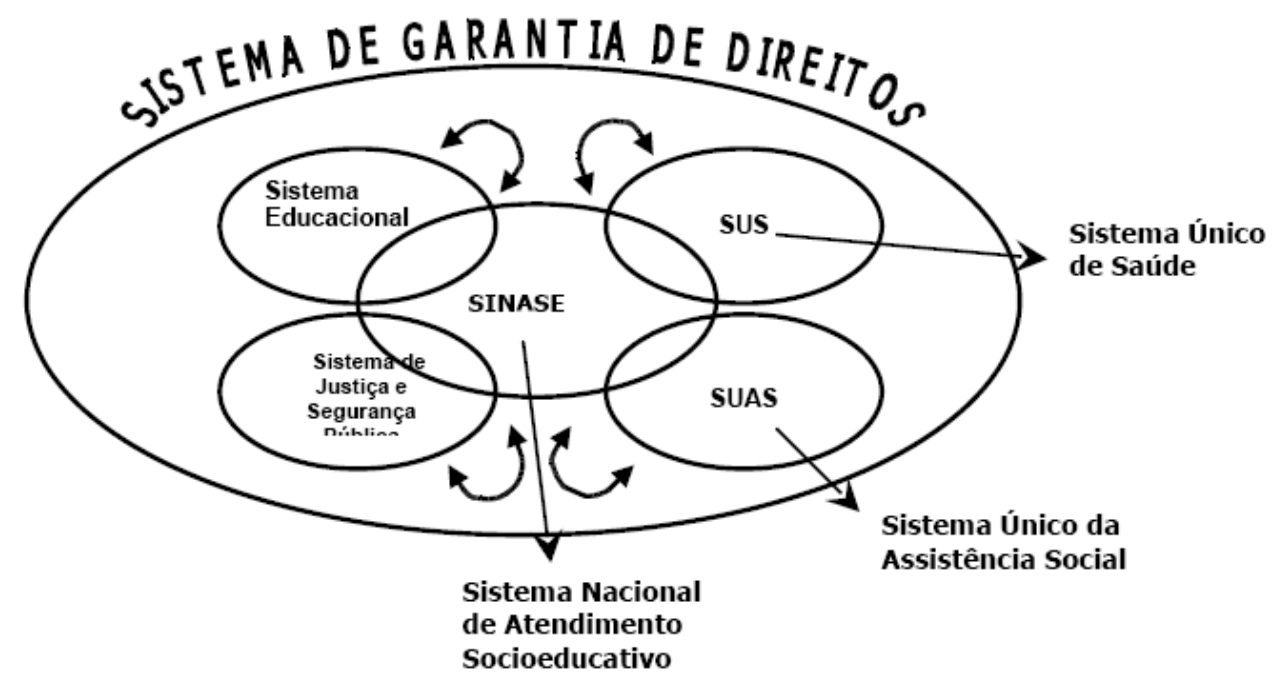

FONTE: Doc. SINASE, 2007, página 23.

Como bem diz Filho (1997:40) "no ECA inexiste a previsão de ação sócioeducativa de iniciativa privada, porque público é o interesse na reeducação e ressocialização do adolescente infrator". Portanto, o SINASE, além de reafirmar a importância da participação da família junto ao adolescente em processo judicial, e da sociedade por meio de Conselhos e ONGs, delega metas e define estrutura coerente à 
aplicação das Medidas Socioeducativas, a fim de sustentar a ação do Estado que é representada pela equipe de trabalho responsável, tanto jurídica quanto executiva ${ }^{51}$.

A sociedade ainda encontra-se marcada por ranço histórico reproduzido pela ideologia punitiva que é alimentada e processada pela mídia sensacionalista que veicula notícias envolvendo "crimes" graves cometidos por adolescentes, criando um imenso “espetáculo" sobre essas situações e suscitando debate polêmico a respeito da redução da idade de inimputabilidade dos adolescentes infratores. A mídia, como meio de informação, formadora de opiniões, aproveita-se da oportunidade para "denunciar a (in)justiça" das autoridades em não impor a "devida" reclusão a esses "delinqüentes", ao passo que angaria os lucros do ibope (SALES, 2007). Em contrapartida, não denunciam a omissão do Estado em prover essas políticas públicas. A sociedade relaciona, por conseqüência, o conceito de justiça com as ações punitivas, expressas por privação de liberdade, e não visualiza o contexto macro do problema a ser combatido.

Por trás do assunto há motivos que aproximam o adolescente da criminalidade que são ignorados, pela sociedade e autoridades, pouco importando os detalhes da trajetória de vida desse jovem ou seu contexto social como elementos que poderiam ser considerados agravantes na análise social do ato infracional. Por este raciocínio, as políticas antecedentes ao ECA centravam-se no ideal de justiça de isolamento deste jovem do meio social, considerados perigosos, e deixavam de investir na reinserção social deste jovem, inclusive como forma de prevenção à sua reincidência nos atos de contravenção penal.

A ruptura com o viés tradicional repressor imposto aos adolescentes autores de ato infracional, processado por longo período no país como resposta de governo aos anseios da sociedade por segurança, é um desafio traçado pela recente lei 8.069/90 (ECA) que defende a (re)socialização desse adolescente através de medidas a serem executadas pelo Estado, compartilhando a colaboração com a família e a sociedade. Filho (1997) discute a mudança de paradigma trazida pelo ECA ao diferenciar as expressões "direito do menor $\mathrm{X}$ direito da criança", demonstrando que este último

\footnotetext{
${ }^{51}$ No caso do Distrito Federal, a VIJ/TJDFT aparece como órgão do judiciário responsável tanto pela fiscalização quanto pela execução das Medidas Socioeducativas em meio aberto, representando o Estado. Incluir-se nesta observação as entidades de execução conveniadas com a VIJ, que recebem os adolescentes para o cumprimento da PSC, como representantes da sociedade civil já que o vínculo voluntário e a participação social são incentivados nesta Medida.
} 
referencia a identidade particular desse grupo social. O termo "menor" conota um sentido pejorativo característico àquela criança ou adolescente fora dos padrões de perfeição, desenquadrada nos moldes e regras sociais, ou por sua condição social ou por seu envolvimento com o crime, distinguindo-os, assim, por categorias distintas e subtraindo-os (LEVISKY,1997).

O ECA apresenta, na Política de Proteção Especial destinada à intervenção junto aos adolescentes autores de ato infracional, instrumentos que defendem os direitos desses sujeitos. No entanto, a execução das propostas de atendimento a esse adolescente depara-se com entraves que dificultam ou minimizam a efetivação do objetivo integral desse trabalho, que não deixa de possuir um caráter preventivo expresso nas atividades de cunho sócio-educativo, ao envolvê-lo numa atmosfera de progresso pessoal e social.

O SINASE veio sustentar e reafirmar as prerrogativas descritas no ECA, confirmando a importância da natureza pedagógica das medidas sócio-educativas no processo de cumprimento pelo adolescente infrator. Essa construção leva em conta o contexto da adolescência brasileira, esclarecendo dados de desigualdades sociais, disparidades raciais, baixa taxa de escolarização dos jovens, taxa de homicídio juvenil e mortalidade infantil, no intuito de reconhecer a realidade de privação e vulnerabilidade sob o qual estão sujeitos.

A índole do adolescente, item julgado no processo de responsabilização jurídica, é também definida por seu meio social que fundamenta a responsabilidade deste jovem em definir suas escolhas. É com sua rede social de relacionamentos (família, amigos, namorado(a)s, e grupos) que o adolescente troca informações e absorve valores e costumes que permearão suas idéias e refletirão em seu comportamento. Por isso, o SINASE emprega a participação da família e da sociedade, junto às atribuições das três esferas do Poder Público (Estado, Municípios e União), como importantes colaboradoras no trabalho de (re)socialização e "incorporação dos adolescentes em conflito com a lei nas diferentes políticas públicas e sociais” (SINASE, 2006, p. 21).

O princípio da "incompletude institucional”, segundo reza o SINASE (2006), baliza o Sistema Socioeducativo quando incentiva ao máximo o acionamento de diferentes ações de políticas sociais, buscando construir uma rede ampla de apoio de serviços e programas, de forma a atender às necessidades do adolescente em 
cumprimento de medida. Essas carências devem ser identificadas pela equipe, que podem ser de âmbito econômico, social, psicológico, cultural, educacional, cognitivo, legal, entre outros.

A Medida Socioeducativa deve desenvolver estratégias de atuação com base pedagógica, através de planejamento de atividades motivadoras, de modo a atingir de maneira positiva o adolescente individual e socialmente. A intenção é proporcionar que ele reconheça-se como cidadão e protagonista de sua realidade, sendo este capaz de transformá-la. Os Conselhos de Direitos da Criança e do Adolescente também são convidados a participar da rede de colaboração como importantes peças dessa integração, visto que são responsáveis pelo controle e avaliação das instituições vinculadas e comportam-se como espaço democrático de representação em prol dos direitos da infância e da juventude.

A Prestação de Serviços à Comunidade (PSC) é caracterizada como uma Medida que deve ser cumprida em "meio-aberto", assim como a Liberdade Assistida, ou seja, em locais, instituições, organismos governamentais ou não-governamentais dentro da comunidade, sem que essa condição comprometa a educação regular do adolescente. $\mathrm{O}$ adolescente designado judicialmente a cumprir tal medida certamente cometeu algum ato infracional leve e está sujeito à realização de serviços comunitários por, no máximo, seis meses. Além da responsabilização, a proposta da PSC intenciona (re) inserir socialmente o adolescente a quem se atribui autoria de ato infracional, desenvolvendose uma agenda de intervenções pautadas em bases pedagógicas, articuladas ao acesso às políticas públicas necessárias, no intuito de fortalecer a identidade desse adolescente e afirmá-lo como protagonista na sociedade, capaz de mudar sua realidade e exercer sua cidadania plena.

\subsection{Operacionalização da PSC no Distrito Federal: Eixo de Articulação com a Rede de Políticas Públicas}

À equipe executora da Medida de PSC, assim como as demais, cabe desenvolver os parâmetros sócio-educativos propostos pelo SINASE e utilizar, para isso, de instrumentos técnico-operativos que permitam manter uma articulação contínua de rede de políticas públicas no processo de atendimento ao adolescente em cumprimento de medida, de modo que o adolescente tenha acesso às políticas de proteção básica, 
preventivas. No Distrito Federal, atualmente a equipe da Seção de Medidas Socioeducativas (SEMSE) da VIJ/TJDFT responsabiliza-se pela execução da PSC, apesar de não possuir papel executivo e sim judicial. A VIJ/TJDFT estabelece convênios com os locais de prestação de serviços interessados e comprometidos com a medida sócio-educativa, sendo que os responsáveis dos locais se dispõem voluntariamente. Na PSC, a sociedade é convidada a participar ativamente no processo de aplicação da medida, na etapa de cumprimento de atividades pelos adolescentes em locais inscritos na comunidade, permitindo a interação do jovem com o meio social.

Os convênios firmados pela VIJ/TJDFT são: CETEFE - Associação de Centro de Treinamento de Ed. Física Especial; UnB - Universidade de Brasília; Rede Sarah De Hospitais de Reabilitação; Lar Dos Velhinhos Bezerra de Menezes, AVHUB Associação dos Voluntários do Hospital Universitário De Brasília, Casa da Sopa Dom Ávila, Secretaria de Estado e Cultura Secretaria de Estado e Cultura, Cesam - Centro Salesiano do Menor, Sobotânica e Fundação Jardim Zoológico de Brasília.

As contribuições variadas da rede de políticas públicas, especialmente direcionadas às crianças e aos adolescentes, complementam-se e tornam a rede substanciada por depender das várias instituições que a compõem. Os princípios da interação e da descentralização norteiam o relacionamento de políticas públicas e transformam a visão de Estado não mais como o único provedor das políticas públicas, permitindo que outros atores sociais participem da referida rede.

O ECA revolucionou o tradicional modelo de atenção/repressão destinado ao adolescente comprometido com a justiça, no qual a conduta desviante do "menor violento" o caracterizava como "problema social". Essa mudança possibilitou renovação fundamental de paradigma ao considerar que o adolescente a quem se atribui autoria de ato infracional é um sujeito possuidor de direitos e que, por muitas vezes, teve seus diretos violados por ser vítima de um contexto de vulnerabilidade, distante das políticas públicas. Portanto, como indica Filho (1997, p. 115) o Estado também é responsável por "boa parte das infrações cometidas, pois sua inação em projetos sociais conduz ao desespero, infectando-os com o delito". Para tornar efetiva tal proposta de atendimento, destaca a importância da "necessidade de se estar constantemente identificando o real interesse desses sujeitos de direito nas opções de implantação de políticas públicas" (VARALDA, 2007, p. 01). 
Tendo em vista a relevância da intenção estatal proposta por um trabalho articulado de redes entre as instituições e serviços disponíveis, prezado por amparo legal aplicado ao atendimento sócio-educativo de adolescente em cumprimento de medida, nota-se que a Prestação de Serviços à Comunidade (PSC) qualifica-se como espaço mediador, capaz de promover a emancipação do adolescente através da sua incorporação no seio das políticas públicas. Os papéis desempenhados pelos executores envolvidos na equipe multiprofissional da PSC definem a qualidade e efetividade de tal medida sócio-educativa, dependente de esforços de atores qualificados para consolidar uma rede integrada de políticas públicas.

Contudo, identifica-se na prática uma fragilidade dessa interação compartilhada da rede de políticas públicas no Distrito Federal, considerando a ausência de diálogo que afirme às instituições suas funções específicas, direcionadas ao adolescente em situação de conflito com a lei, bem como a própria dificuldade de operacionalização da Medida Socioeducativa em função de limites estruturais e de recursos. As etapas do processo de responsabilização do adolescente autor de ato infracional, representadas pelas instituições da rede que o recebe, acontecem no DF sob a administração de órgãos jurídicos (VIJ, Delegacia, Ministério Público, Promotoria) que desempenham com eficácia o trabalho de aplicação das Medidas Socioeducativas, apesar de estarem assumindo carga excessiva de responsabilidade, visto que não há atuação articulada com os setores de governo do Poder Executivo (Ver anexo 1).

A operacionalização das Medidas Socioeducativas segue processo de atendimento ao adolescente infrator através de entidades responsáveis por investigar a apuração do ato infracional até a aplicação ou remissão das medidas cabíveis. A rede de atenção deveria funcionar de maneira articulada, garantindo ao adolescente o apoio jurídico necessário em todas as etapas do processo e o cumprimento dos serviços de acordo com suas potencialidades. O momento atual, durante o ano de 2009, é de transição institucional da gestão das Medidas Socioeducativas de meio aberto, sempre antes desempenhada pela VIJ/TJDFT em caráter provisório, para a SEJUS. Essa adequação se deu a partir de discussões interinstitucionais, composta pela rede de atenção ao adolescente, no intuito de aplicar os parâmetros de operacionalização estabelecidos pelo SINASE. O objetivo desta mudança apresenta-se como forma de efetivação de um trabalho de qualidade no atendimento ao adolescente em conflito com 
a lei, em consonância com as diretrizes do SINASE. Contudo, haverá implicações que deverão ser medidas posteriormente ao estabelecimento deste processo, bem como o impacto desta mudança, tendo em vista a capacidade estrutural e conjuntural da SEJUS em assumir esta nova responsabilidade, com todos os desafios de implementação de uma política voltada ao adolescente autor de ato infracional de acordo com o SINASE.

Nota-se que, o que acontece na aplicação das Medidas Socioeducativas no DF, no geral, encontra-se representado no esquema anexado (Anexo 1), composto por instituições que limitam-se ao desempenho jurídico de responsabilização do adolescente, resumindo a rede de atenção ao adolescente infrator à ordem vertical do fluxograma. Do momento em que o adolescente é recebido pelas instituições competentes, e aguarda julgamento, até o período pós-cumprimento da medida sócioeducativa definida, a equipe de atendimento central do Sistema Socioeducativo tem por meta desenvolver atuação articulada com outros programas de diferentes áreas de políticas públicas, além de promover atividades internas grupais, e prestar atendimento individual e familiar, como forma de acompanhamento proposto no SINASE.

A PSC caracteriza-se como uma Medida Socioeducativa imposta àqueles jovens que cometeram infrações consideradas leves pela primeira vez, na maioria por falta de habilitação, roubo e lesão corporal, e porte de drogas (SANTOS, 2000). A pesquisa realizada por Santos, no local de Prestação de Serviços da Universidade de Brasília (PeSC), aponta que há adolescentes de diversas classes sociais cumprindo tal Medida Socioeducativa, com diferentes níveis de renda.

A reinserção social deste jovem na sua rede social básica (família, comunidade, escola, trabalho) foi verificada positivamente pela pesquisa citada, destacando o fato dos vínculos familiares destes adolescentes não encontrarem-se fragilizados em sua maioria. Contudo, a avaliação do impacto da medida executada pelo PeSC/UnB não permite identificar se houve trabalho da equipe de acionamento da rede de políticas públicas que viesse oferecer suporte ao cumprimento da Medida Sócio-educativas e que propiciasse a integração dos adolescentes egressos em sua rede social. A aplicação destas Medidas educacionais/protetivas deve ser executada de modo que o adolescente seja responsabilizado no processo de atividades pedagógicas, desenvolvidas ao longo do tempo de serviço a ser cumprido, contando com a emancipação social deste jovem, 
proporcionada pelo acesso às políticas públicas viabilizado pelo atendimento de redes exigido na Medida Socioeducativa.

Como solução à dificuldade de executar tal política, o próprio SINASE reconhece as lacunas nos serviços e elenca mudanças necessárias que merecem ser consideras aqui, dentre elas destacam-se:

1) A ampliação do Sistema em meio aberto;

2) Organização da rede de atendimento;

3) Pleno funcionamento do sistema de defesa do adolescente;

4) Regionalização do atendimento e municipalização do meio aberto;

5) Capacitação dos atores sócio-educativos;

6) Elaboração de uma política estadual (ou distrital) de atendimento, integrada às demais políticas;

7) Ação dos conselhos, ampliação das varas;

8) Entendimento da lei;

9) Integração dos órgãos jurídicos: Ministério Público, Defensoria, Segurança Público, Assistência Social;

10) Atendimento estruturado e qualificado dos egressos.

$\mathrm{O}$ referido entendimento do conjunto de leis direcionado à defesa dos direitos da criança e do adolescente é fator fundamental a ser conhecido pelo corpo técnico de execução das Medidas Sócio-educativas, não só para obedecerem na estrutura prática, mas também para prestar função de informar os adolescentes e suas famílias. Ao cumprimento da Medida, o apoio deve ser pautado minimamente tanto em relação ao ECA quanto ao SINASE. Esse princípio está inserido na sugestão de capacitação dos atores sócio-educativos, importante medida a ser investida em prol da qualidade dos recursos humanos da área. $\mathrm{O}$ assistente social é um profissional cuja formação possibilita o desenvolvimento de trabalho em redes de forma que a presença de tal profissional em instituições executoras da medida em questão configura-se como uma necessidade premente. O Serviço Social aparece hoje no cenário de equipes 
multiprofissionais como uma categoria fundamental ao andamento de determinada instituição e de suas ações, principalmente por desempenhar em suas funções uma análise social adequada, conseguindo abranger o contexto geral envolvido na interpretação das problemáticas específicas.

A equipe mínima de PSC, indicada pelo SINASE, deve ser constituída por:

1) 01 técnico para cada vinte adolescentes;

2) 01 Referência sócio-educativa para cada grupo de até dez adolescentes e um orientador sócio-educativo para até dois adolescentes simultaneamente a fim de garantir a individualização do atendimento que a medida pressupõe.

Neste caso, a PSC não exige que o profissional de nível superior responsável pela coordenação do programa, no encargo de "Referência sócio-educativa", seja formado em Serviço Social, sendo questionável a atuação do mesmo com relação a formulação e aplicação de medidas efetivas que possibilitem a articulação de políticas públicas disponíveis na Rede de Atenção ao Adolescente no Distrito Federal (BRASIL, 2006).

A rede de atendimento ao adolescente em conflito com a lei encontra-se organizada, no DF, com base nas condições mínimas de funcionamento do sistema estrutural observado no fluxograma de responsabilização deste jovem, formado por instituições responsáveis pelo cumprimento da Medida Sócio-educativa, ao limite do período estabelecido. Tem-se como prerrogativa que sem uma atuação ampliada de políticas públicas que venha a oferecer suporte às necessidades desse adolescente, $o$ processo de efetivação dos objetivos de reinserção social do jovem tão trabalhado dentro da PSC seja dificultado. O esforço de construção do projeto de futuro feito pelo adolescente durante o período de cumprimento da PSC, no qual é transmitido a ele a possibilidade de ser protagonista de sua história, pode não ser efetivado quando o jovem se depara com barreiras da realidade inacessível ou inexistente de políticas públicas que venham a suprir suas necessidades sociais, como a carência de política de profissionalização para a juventude.

A ausência de uma política distrital de atendimento Socioeducativo se mostra como problemática agravante na dificuldade de consolidação de um atendimento que preze a integração entre a rede de políticas públicas, pois distancia a necessidade de 
compartilhar a responsabilidade da atenção ao adolescente autor de ato infracional com outras áreas. A mudança de gestão dessa política de atendimento entre secretarias do Governo do Distrito Federal (GDF) trava, no momento, a proposta de se construir um projeto específico regionalizado de atenção ao adolescente em cumprimento de Medida Sócio-educativa, e confunde as ações destinadas a esse público entre as diversas áreas da rede de políticas.

O SINASE indica medidas favoráveis à promoção dse um atendimento articulado, entre eles:

1) estímulo à prática da intersetorialidade;

2) campanhas conjuntas destinadas à sociedade em geral e aos profissionais da área, com vistas à concretização da Doutrina de Proteção Integral adotada pelo ECA;

3) promoção de discussões, encontros, seminários (gerais e temáticos) conjuntos;

4) respeito às competências e atribuições de cada ente federativo e de seus órgãos, evitando-se a sobreposição de ações;

5) discussão e elaboração, com os demais setores do Poder Público, para expedição de atos normativos que visem ao aprimoramento do sistema de atendimento;

6) expedição de resoluções conjuntas, disciplinando matérias relacionadas à atenção a adolescentes inseridos no SINASE.

Dentro dos parâmetros sócio-educativos que devem ser trabalhados pela equipe multiprofissional de todas as medidas, o SINASE determina como essenciais os seguintes eixos: suporte institucional e pedagógico; diversidade étnico-racial, de gênero e de orientação sexual; cultura, esporte e lazer; saúde; escola; profissionalização/trabalho/previdência; família e comunidade e segurança (BRASIL, 2006, pg. 23). O acesso a esses eixos depende de posturas assumidas pelas equipes profissionais em seus trabalhos de execução da medida, no intuito de viabilizar a incorporação do adolescente às políticas públicas citadas.

Existe um manual de operacionalização da PSC (2000) adequada à realidade da região de Goiás, elaborado pela Secretaria de Cidadania e Trabalho sob a qual a respectiva Medida encontra-se subordinada à gestão executiva. É uma proposta prática 
que resgata conceitos e traça parâmetros a serem adotados pelas autoridades competentes. No Distrito Federal não há construções semelhantes que definam metas e objetivos específicos a seu contexto regional, sendo alertada aqui a necessidade de construção de tal material a fim de registrar responsabilidades das equipes engajadas.

Para se obter uma noção ampliada da problemática que envolve as implicações colocadas entre a execução da PSC e o trabalho desempenhado junto à rede de políticas públicas, é necessário analisar em que medida as equipes executoras da Prestação de Serviços a Comunidade desenvolvem, na operacionalização da seguinte Medida Socioeducativa, um trabalho de articulação com a Rede de Atenção ao Adolescente no Distrito Federal. Entende-se que a partir de tal análise será possível compreender se equipes de execução da PSC realmente desenvolvem trabalho articulado com a rede de políticas públicas por reconhecerem-na como ferramenta de intervenção, bem como identificar os desafios e limites que impedem a realização de um trabalho completo de articulação, como sugere o SINASE. 


\section{CAPÍTULO V - ANÁlise dA OPERACIONALIZAÇÃO DA PRESTAÇÃo DE SERVIÇOS A COMUNIDAdE E A ARTICULAÇÃO COM A REDE DE POLÍTICAS PÚBLICAS}

\subsection{Objetivos da Pesquisa}

Este trabalho centra-se na abordagem da Prestação de Serviços a Comunidade, considerando suas características de Medida Socioeducativa aplicada em meio aberto, que proporciona proximidade do adolescente com a comunidade e é sentenciada sob atos infracionais considerados "leves", ou seja, de pouca gravidade. Às equipes envolvidas na execução da PSC, VIJ e entidades sociais, cabe a função de promoverem um trabalho articulado com a rede de políticas públicas disponíveis no DF, a fim de desenvolverem um atendimento que realmente venha resgatar o adolescente envolvido em ato infracional, adequado às suas necessidades pessoais e sociais. Tendo em vista a indicação do SINASE em estabelecer-se, na aplicação das Medidas, um trabalho de forma articulada junto à rede de políticas públicas, este trabalho de monografia propõe analisar como vem sendo aplicado este princípio na Medida de PSC, a partir da seguinte estrutura de pesquisa:

\section{Pergunta de Pesquisa}

Na operacionalização da PSC, de que forma está sendo desenvolvido o trabalho em articulação com a Rede de Atenção ao Adolescente no Distrito Federal, no contexto de execução desta Medida Socioeducativa?

\section{Objetivo Geral}

Analisar em que medida as equipes executoras da Prestação de Serviços a Comunidade desenvolvem, na operacionalização desta Medida Socioeducativa, um trabalho de articulação com a Rede de Atenção ao Adolescente no Distrito Federal.

\section{Objetivos Específicos}

- Compreender como se consolida a atual dinâmica operacional e de atividades desenvolvidas nos locais de cumprimento da PSC pelas equipes de execução.

- Verificar o posicionamento das equipes que executam a PSC a respeito da necessidade de articulação com a Rede de Atenção ao Adolescente no DF. 
- Averiguar como e em quais circunstâncias as equipes de execução da PSC realizam um atendimento integrado com as instituições da Rede disponíveis no DF.

- Identificar as potencialidades e os limites enfrentados pelos executores da PSC em utilizar-se da Rede de Atenção ao Adolescente como ferramenta de trabalho.

A partir destes objetivos desenvolveu-se pesquisa social analítica que permitiu verificar respostas concretas às questões que envolvem a realidade da aplicação das Medidas Socioeducativas, em especial a PSC, sentenciadas ao adolescente autor de ato infracional. O trabalho foi balizado pela seguinte hipótese:

As equipes de execução da Medida Socioeducativa de Prestação de Serviços à Comunidade desempenham um trabalho limitado de articulação junto à Rede de Atenção ao Adolescente no Distrito Federal, de forma que a rede é utilizada apenas em sua capacidade mínima, ou seja, para manter o funcionamento da operacionalização da Medida, o que se restringe ao cumprimento dos serviços locais durante o tempo determinado judicialmente.

Este fato tem uma repercussão decisiva no fator educacional, que segundo a lei deveria ser prioritário em relação ao fator punitivo, caracterizando uma intervenção imediatista. Isso se deve, também, às precárias condições estruturais da medida, que se traduzem pela insuficiência de respaldo institucional dos locais de execução da PSC e dos escassos recursos humanos qualificados e recursos financeiros que viabilizem a utilização da rede de políticas públicas como ferramenta para emancipação e (re) inserção social do adolescente autor de ato infracional, fatores causais que foram investigados.

Vale destacar que a instabilidade observada na estrutura administrativa responsável pela gestão da operacionalização das Medidas Socioeducativas em meio aberto no Distrito Federal, sendo a VIJ considerada executora provisória até este ano de 2009, exerceu influências na constituição da atual conjuntura da política de atenção ao adolescente infrator desenvolvida, inclusive limitando as ações das equipes de execução pelo próprio caráter provisório da gestão. A ausência de estratégias e metas no âmbito do Distrito Federal, que deveriam ser formuladas a partir de discussões em conjunto entre as instituições envolvidas com operacionalização da PSC, também sucede como causa inibidora da execução de trabalho baseado em articulação de redes. A transferência da VIJ para a SEJUS aparece como meio provável de solucionar esta situação inapropriada, com a adequação da instituição responsável pelo ordenamento e 
aplicação das Medidas Socioeducativas, a serem desempenhas segundo as recomendações do ECA e do SINASE.

\subsection{Procedimentos Metodológicos}

No ensejo de contemplar no trabalho as conclusões aos questionamentos relativos à realidade do adolescente atendido no Distrito Federal pelo Sistema Socioeducativo, na Medida de PSC, a estratégia escolhida de pesquisa de campo exigiu da pesquisadora uma investigação prévia de estudos exploratórios em fontes primárias e secundárias que serviram de suporte para a etapa do contato direto com os sujeitos de pesquisa. Deste modo, entende-se que o método de pesquisa de campo conciliado com a pesquisa bibliográfica como meio mais adequado de atingir aos objetivos propostos na pesquisa, ou seja, possibilitou traçar a visão da equipe que lida com a execução da PSC sobre a articulação de redes de políticas públicas.

A intenção de análise deste estudo enquadra-se no campo da pesquisa social, interessada em abranger a realidade do campo institucional das Medidas Socioeducativas, a exemplo da PSC. Tal esforço científico vislumbrou a construção de um produto contributivo, proporcionado pela pesquisa de caráter aplicado segundo Ander-Egg, no sentido de que os resultados possam servir de base para a aplicação de intervenções que venham aprimorar a execução das Medidas Socioeducativas no trabalho articulado junto à rede de políticas públicas (apud MARCONI; LAKATOS, 1982). Para tanto, esta análise pretendeu definir alguns questionamentos práticos quanto à execução da Medida, realizada pelas instituições responsáveis pela aplicação da PSC. Tal estudo foi efetivado a partir da análise dos discursos dos principais atores envolvidos na equipe de execução da PSC no Distrito Federal, por meio das seguintes etapas realizadas:

$1^{\text {a) }}$ Entrevistas semi-estruturadas com as equipes envolvidas no processo de execução da Medida Socioeducativa de PSC, ou seja:

- 2 Psicólogos da VIJ/TJDFT, responsáveis da Seção de Medidas SocioEducativas (SEMSE) pela PSC, considerados Técnicos no SINASE;

- 1 Assistente Social da VIJ/TJDFT, integrante da equipe da SEMSE, que já colaborou à frente da equipe responsável pela PSC; 
- 2 coordenadores de locais diferentes de cumprimento de serviços, considerados Referências Socioeducativas pelo SINASE ${ }^{52}$.

Os coordenadores foram selecionados a partir da formação acadêmica - 1 psicóloga e 1 assistente social - e do lócus de cumprimento da Medida, ambos no espaço da Universidade de Brasília - UnB. Foram escolhidos os dois espaços conveniados de execução da PSC na Universidade de Brasília - PeSC/UnB e AVHUB. Pretende-se com esta metodologia notar distinções quanto à capacidade dos mesmos em desenvolver a função sócio-educativa articuladamente com a rede de políticas públicas, segundo suas qualificações e os recursos disponíveis.

$2^{\text {a) }}$ Para a complementação da pesquisa, foi realizada entrevista semi-estruturada com servidor da SEJUS ligado à subsecretaria responsável, visto que a mesma assumirá a partir deste ano de 2009 a gestão das Medidas Socioeducativas, no intuito de identificar os objetivos da mudança de secretarias bem como conhecer as novas propostas de aplicação da Medida de PSC, inclusive quanto às perspectivas e estratégias de articulação com a rede de políticas públicas.

Diferente do propósito valorativo objetivado em avaliações de programas (WORTHEN et al, 2005), os procedimentos de análise aplicados nesta pesquisa foram baseados substancialmente nos dados extraídos das entrevistas qualitativas. O olhar crítico dos profissionais envolvidos na operacionalização da PSC a respeito de suas avaliações pessoais, construídas por suas experiências e vivências na área de aplicação desta Medida e relacionado ao trabalho articulado em redes de políticas públicas, foi analisado de acordo com os objetivos questionados. As categorias investigadas nos objetivos foram exploradas no intuito de identificar a

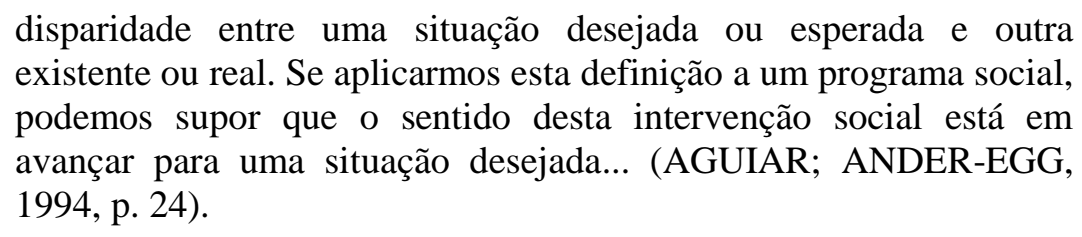

Concluindo, esta análise foi pautada nos princípios legislativos que definem como eixo fundamental a articulação em redes de políticas públicas na aplicação das Medidas Socioeducativas. As entrevistas contaram com instrumentais de suporte: dois roteiros direcionados aos sujeitos de pesquisa, com perguntas simples, flexíveis e que permitiram o desenvolvimento da conversa conforme os objetivos da pesquisa. Este

\footnotetext{
${ }^{52}$ A amostra selecionada corresponde a $25 \%$ do total de instituições conveniadas.
} 
recurso intuiu guiar a pesquisadora aos tópicos importantes a serem captados, a fim de que os depoimentos dos sujeitos de pesquisa revelassem dados relevantes capazes de testar a hipótese do trabalho para, assim, contemplar os objetivos da pesquisa. Apropriando-se das sugestões metodológicas de Lodi (1991), para se estabelecer o desenvolvimento da entrevista foi necessário que a entrevistadora partisse da apresentação dos objetivos do projeto, no intuito de firmar uma confiabilidade entre pesquisadora/entrevistado e ampliar a dinâmica da entrevista para além das questões do roteiro.

Quanto aos registros, a pesquisadora tomou nota durante as entrevistas, além do recurso de gravação, utilizado para facilitar o processamento mais preciso e completo dos dados captados nos depoimentos. Deste modo, se obteve uma análise mais rica e consistente conferido na estruturação do trabalho escrito. Após a conclusão do trabalho e construído o produto da pesquisa, uma síntese será apresentada aos atores pesquisados no intuito de informá-los dos resultados obtidos. Esta síntese será divulgada via email para os sujeitos de pesquisa, lhes garantido o direito à informação dos resultados do trabalho.

Por fim, as entrevistas demandaram por parte da pesquisadora a formulação de um termo de consentimento livre e esclarecido que foi devidamente assinado tanto pelo pesquisador quanto pelo entrevistado, tendo cada um o direito a posse de uma via. É o comprovante da colaboração do sujeito de pesquisa e da aceitação quanto às premissas da pesquisa, sendo garantido seu sigilo através do anonimato tanto no trabalho escrito quanto na apresentação oral. Resguarda-se, ainda, a liberdade de desistência do entrevistado em prestar seu depoimento durante qualquer momento da entrevista.

\subsection{Análise dos Dados Coletados}

\subsubsection{Equipe de Técnicos da SEMSE/VIJ/TJDFT}

Atualmente, a equipe de Técnicos da SEMSE/VIJ/TJDFT responsável pela execução da PSC é composta por dois psicólogos que estão à frente do acompanhamento de adolescentes encaminhados pelo juiz para cumprirem tal Medida, ambos foram entrevistados. De acordo com o SINASE é sugerido no mínimo um técnico para cada vinte adolescentes, a considerar que no caso da PSC existe uma rotatividade na demanda que acontece com o término de cumprimento da Medida. Questionados quanto ao tempo de envolvimento com a execução da PSC, os referidos 
profissionais revelaram que um atua há sete anos, enquanto o outro há três anos. Um entrevistado informou já ter colaborado anteriormente na aplicação da Medida de Liberdade Assistida, também executada pela SEMSE/VIJ/TJDFT até então. Houve a confirmação do papel do Poder Judiciário, representado pela VIJ/TJDFT, em desenvolver trabalho de execução das Medidas Socioeducativas no DF desde o exercício prático das inovações institucionalizadas pelo ECA com relação a aplicabilidade destas Medidas, consolidado por volta do ano de 1992, acontecimento inapropriado segundo a legislação que confere ao Poder Executivo esta tarefa, cabendo ao judiciário apenas a função de fiscalizar e normatizar.

Como ponto de partida da investigação, considerou-se pontual identificar a concepção dos profissionais quanto ao conceito de "Socioeducativo" apropriado por eles no intuito de verificar o esclarecimento dos mesmos quanto aos objetivos das Medidas, refletidos nos mecanismos utilizados na abordagem de atendimento ao adolescente desempenhada pela equipe. Percebeu-se semelhança no discurso dos dois psicólogos em considerar o Socioeducativo como meta de ressocialização do adolescente, associada a sua responsabilização pelo ato infracional cometido. As duas categorias citadas foram definidas da seguinte maneira:

$1^{\circ}$ - a responsabilização compreende a conscientização do adolescente de que ele cometeu o ato infracional;

$2^{\circ}$ - a ressocialização é entendida como uma reparação do dano cometido à sociedade.

Desse modo, para os profissionais em questão, o cumprimento da Medida Socioeducativa significa um momento em que o adolescente está prestando à sociedade contas do ato infracional cometido "ao mesmo tempo em que está aprendendo, sendo ressocializado" (sic). Um dos psicólogos acrescentou, utilizando-se de outro termo equivalente à "ressocialização", que seria a REINSERÇÃO do adolescente como um sujeito de direitos e deveres dentro da sociedade. Foi feita referência ao espaço Socioeducativo como oportunidade de reeducação através das atividades propostas pelas Medidas, tendo em vista como causa o fato do adolescente ter sido "mal educado" (sic) até aquele momento, no sentido de "moldar e reeducar para viver em sociedade" (sic). Colocou-se, ainda, que a oportunidade oferecida pela PSC de reparação do erro 
cometido, através da educação, consiste na reflexão que o adolescente faz durante o cumprimento da Medida para haver uma mudança.

Foram prestados esclarecimentos quanto ao processo jurídico de encaminhamento e acompanhamento do adolescente autor de ato infracional ao cumprimento da PSC, sendo citadas as funções desempenhadas pela equipe da SEMSE. A Delegacia da Criança e do Adolescente - DCA - é a "porta de entrada" sob a qual o adolescente chega ao Sistema Socioeducativo quando há suspeita do cometimento de infração de sua autoria ${ }^{53}$. Efetivado este primeiro atendimento, o adolescente aguarda representação do Ministério Público (MP) em oitiva onde o promotor decide na maioria dos casos por um acordo com o adolescente, conhecido como a remissão ${ }^{54}$, no qual se determina um tempo de cumprimento de Medida Socioeducativa e o arquivamento do processo. Em todos os casos, mesmo sendo acatada - homologada - a sugestão do promotor pelo juiz em posterior audiência, as determinações são tomadas ciência no cartório e o adolescente é encaminhado à VIJ/TJDFT para ser acompanhado durante o cumprimento da "sentença".

A equipe da SEMSE realiza, então, um trabalho inicial de orientação aos adolescentes e suas respectivas famílias, representadas por seus responsáveis, através de entrevistas. Em reunião convocada, é prestada explicação coletiva a respeito das questões que envolvem o ato infracional, bem como em que consiste a PSC, buscando mostrar que "vem do ECA" (sic). Sendo passadas as devidas informações quanto ao andamento da aplicação da Medida, o adolescente aguarda ser inserido em vaga, podendo ser distribuído para uma das entidades de prestação de serviços conveniadas à VIJ atualmente no DF. Nos depoimentos, foi destacada a dependência de instituições governamentais e não-governamentais no caso da Medida de PSC, tendo em vista que

\footnotetext{
${ }^{53}$ Importante frisar que a DCA pode ser considerada a "porta de entrada" direta ou indireta do adolescente no Sistema Socioeducativo, tendo em vista a participação de outros organismos integrantes da rede de políticas públicas (ver Anexo 1) que detectam o cometimento de ato infracional e encaminham o adolescente à instituição competente, à DCA para que seja feito os encaminhamentos posteriores de responsabilização segundo o fluxograma.

${ }^{54}$ A remissão trata-se de um acordo entre o MP e adolescente para que o processo seja arquivado com a aplicação da Medida Socioeducativa (Artigo 126 do ECA). Em remissão não há um processo investigativo, não há apuração do ato infracional. A maioria dos adolescentes chega à SEMSE/VIJ por remissão. Diante da história, do relato do adolescente em oitiva, o promotor avalia se o mesmo teve haver com o ato infracional, entra-se num acordo e indica-se a acumulação com Medidas Socioeducativas.
} 
sua realização se dá nestes espaços da comunidade sendo alertada a necessidade de firmar tais convênios. Em relato, um psicólogo afirmou que há esforço da equipe da SEMSE na tentativa de encaminhar o adolescente à Medida no mesmo dia em que é apresentado na seção, "seria o ideal, mas só aconteceram duas vezes" (sic) devido à falta de vagas disponíveis nas poucas instituições parceiras. Além disso, a inserção em campo depende da coincidência do momento em que a instituição está recebendo o adolescente, bem como do cronograma e disponibilidade institucionais para recebê-lo. "O adolescente chega a aguardar até um ano pra ser chamado" (sic). Observa-se nesse ponto uma brecha significativa da operacionalização da PSC que pode acarretar em casos de reincidência de novos atos infracionais por estes adolescentes que não foram amparados de imediato, inclusive com o acúmulo de Medidas Socioeducativas por infrações cometidas de maneira sucessiva e que não foram reparadas.

Junto à família, a orientação da SEMSE busca incentivar o envolvimento e o apoio que deve ser assumido compartilhado ao adolescente para que ele seja capaz de cumprir a Medida. Os pais, ou responsáveis, também são responsabilizados pelo ato infracional e pela Medida a ser cumprida, sendo constatado a mãe como principal à acompanha o filho neste processo. Corriqueiramente, por ser determinada em caso de infração de baixo poder ofensivo, há juízes que definem um ou dois meses de cumprimento de PSC.

O trabalho de orientação executado pela VIJ conta com instrumentais como a ficha de evolução, por exemplo, no intuito de registrar o perfil do adolescente e coletar os dados do mesmo, para posterior comunicação e convocação com o aviso de abertura de vagas. Os contatos são feitos por telefone e são informados onde há vagas, a partir da análise da proximidade da moradia do adolescente e de acordo com o perfil do mesmo. A instituição conveniada que mais recebe os adolescentes hoje é a Secretaria de Cultura, com 30 vagas disponíveis, distribuídas por vários locais de serviços como no Museu da Imagem Candanga e no Teatro Nacional em Brasília.

Ao longo do tempo de cumprimento da Medida, há documentos de preenchimento obrigatórios reconhecidos como comprovantes de cumprimento da mesma, seriam as listas de freqüência e uma avaliação ao final da Medida, que devem ser controladas pelos coordenadores dos locais de prestação de serviços e repassadas à SEMSE para ser encaminhado ao MP, que avalia se a Medida foi bem cumprida ou não, 
finalmente devendo ser apresentadas ao juiz da VIJ para homologação. O compromisso burocrático das instituições para com a VIJ foi apontado como um dos empecilhos para a efetivação de convênios tendo em vista a necessidade dos coordenadores responsáveis prestarem contas à SEMSE do que foi produzido.

Das dificuldades em firmar convênios, a equipe profissional da SEMSE atribui ao fator preconceito ainda imbricado na cultural da sociedade, conseqüentemente reproduzidos pelos atores institucionais que recusam o vínculo de parceria, em relação ao risco iminente que o adolescente autor de ato infracional representa por sua situação de "conflito com a lei". A possibilidade do adolescente cometer outro ato dentro da instituição é sempre cogitada. Diante dos problemas agravados por conta das poucas vagas existentes, bem como a instabilidade dos campos disponíveis que não raramente fecham o convênio por mudanças na direção institucional, a equipe da SEMSE investiu em mobilizações na tentativa de conseguir estabelecimento de parcerias por meio de reuniões e/ou mutirões com a preparação de materiais e folhetos explicativos sobre a PSC para tentar sensibilizar e esclarecer aos representantes das instituições interessadas a dinâmica de funcionamento e a importância do trabalho Socioeducativo, inclusive apresentando a minuta com o termo de convênio. No entanto, os resultados de tais investidas não foram tão consideráveis conforme as expectativas, como numa ocasião em que apenas dois convênios foram efetivados numa tentativa com vinte instituições. “Todos aceitam de bom grado analisar a proposta, mas não fecham" (sic).

Apesar das dificuldades, a qualidade na dinâmica desenvolvida durante o cumprimento dos serviços foi citada como diferencial importante apresentado por algumas instituições, como no caso da organização não-governamental da Zoobotânica do Jardim Botânico que só atendeu uma turma de quatro adolescentes por um período, mas obteve um bom resultado em termos de materiais com a produção de uma apostila construída pelos trabalhos dos adolescentes. Há locais de prestação que não se empenham em incrementar o atendimento, limitam-se ao acompanhamento dos adolescentes nos serviços e à entrega do relatório de desligamento com a avaliação do tutor do local que devem ser passado à SEMSE/VIJ, como exposto pelo entrevistado.

Com relação ao foco específico do desenvolvimento de um trabalho de execução da PSC, desempenhado pela equipe SEMSE, em articulação com a rede de políticas públicas, um psicólogo informou que os encaminhamentos às instituições são feitos 
informalmente quando se detecta a necessidade do adolescente ser atendido em área como de saúde ou de educação, por exemplo. A indicação que pode ser considerada de caráter formal é aquela decidida em audiência determinada pelo juiz da VIJ, equiparada como Medida Protetiva. As Medidas Protetivas estão elencadas no ECA em seu Artigo 101 e que podem ser acumuladas com as Medidas Socioeducativas ${ }^{55}$, são elas:

\footnotetext{
"I - encaminhamento aos pais ou responsável, mediante termo de responsabilidade;

II - orientação, apoio e acompanhamento temporários;

III - matrícula e frequiência obrigatórias em estabelecimento oficial de ensino fundamental;

IV - inclusão em programa comunitário ou oficial de auxílio à família, à criança e ao adolescente;

V - requisição de tratamento médico, psicológico ou psiquiátrico, em regime hospitalar ou ambulatorial;

VI - inclusão em programa oficial ou comunitário de auxílio, orientação e tratamento a alcoólatras e toxicômanos;

VII - abrigo em entidade;

VIII - colocação em família substituta.

Parágrafo único. O abrigo é medida provisória e excepcional, utilizável como forma de transição para a colocação em família substituta, não implicando privação de liberdade.

VII - acolhimento institucional; (Redação dada pela Lei ${ }^{\circ} 12.010$, de 2009) Vigência

VIII - inclusão em programa de acolhimento familiar; (Redação dada pela Lei n ${ }^{\circ} 12.010$, de 2009) Vigência

IX - colocação em família substituta. (Incluído pela Lei nº 12.010, de 2009) Vigência"
}

Geralmente as Medidas Protetivas são indicadas havendo a necessidade de efetivação de matrícula escolar ou quando o adolescente possui algum impedimento na área de saúde mental, como problemas de dependência química ou precisão de

\footnotetext{
${ }^{55}$ Medida Protetiva pode estar cumulada com a Medida Socioeducativa (aquelas dispostas no Art. 101 do ECA). Os encaminhamentos realizados pela equipe da SEMSE às instituições da rede de atenção ao adolescente no DF acontecem bastante em função da cumulação com Medidas Protetivas aplicadas pelo juiz da VIJ/TJDFT. O acompanhamento das Medidas Protetivas fica ao encargo do Conselho Tutelar. No entanto, mesmo sem a solicitação do juiz a equipe da SEMSE pode realizar tais encaminhamentos de maneira informal, conforme a necessidade do jovem.
} 
atendimento médico-psiquiatra. No entanto, mesmo quando não é determinada judicialmente em audiência uma Medida Protetiva, a SEMSE realiza encaminhamentos informais, sempre comunicando ao juiz por relatório baseado em estudo psicossocial que justifique a necessidade do encaminhamento.

$\mathrm{Na}$ visão de um dos psicólogos, a interação com a Rede de Atenção ao adolescente disponível no DF é mais exigida na aplicação da Medida Socioeducativa de Liberdade Assistida (LA). Segundo o declarante, a equipe da SEMSE realizava esta orientação junto à rede de políticas públicas na LA até sua transferência para a SEJUS, há um ano. Para a PSC, o esforço concentra-se em estabelecerem os convênios, ou seja, o enfoque está na Medida Socioeducativa em si. Mesmo assim, a função de articular com a "rede solidária" (sic) é desempenhada quando, na orientação, se detecta algum problema, então a lista de instituições é acionada onde há vaga. Quando o adolescente encontra-se imerso na situação infracional por não possuir ocupação, a SEMSE viabiliza cursos oferecidos por instituições da rede, como na Casa de Ismael ou no SENAC, por exemplo. Entretanto, a maioria dos adolescentes não tem condições de aproveitarem as oportunidades por motivo de distância das moradias e dificuldades financeiras que os impedem de pagar a passagem. A rede deveria funcionar no sentido de viabilizar inclusive o acesso deste adolescente aos programas através de auxílios. No entanto, reconhece-se que há carência de serviços e condições que possibilitem efetivar tal proposta. Seriam necessários investimentos públicos nesta área voltados à proteção integral deste adolescente.

O trabalho articulado em rede desempenhado pela SEMSE obedece ao trâmite legal, ou seja, consideram-se as indicações do juiz. Na audiência com o juiz, o promotor fala em defesa do adolescente e, nos casos de maior gravidade, o juiz se manifesta podendo solicitar um estudo mais aprofundado de determinado caso. Este procedimento "não é feito com todos os adolescentes" (sic). Quando o juiz identifica algum comprometimento apresentado pelo adolescente (dependência química, por exemplo), notifica-se à equipe da SEMSE solicitando um estudo com pormenores da situação para consubstanciar os devidos encaminhamentos. A intervenção da SEMSE, neste sentido, seria verificar a instituição mais adequada para o atendimento do adolescente. Todavia, mesmo sem a solicitação do juiz, na entrevista de orientação aplicada pela SEMSE é verificada a necessidade de encaminhamento do adolescente aos 
serviços competentes, sempre atendendo a exigência de comunicação ao juiz quando a equipe faz algo além do que o determinado. Neste ponto vale frisar que o compromisso ético-profissional permite ir além das determinações judiciais no sentido do aprofundamento das situações no intuito de prestar uma contribuição jurídica/social que possa atingir de forma positiva o adolescente e sua família.

Nos encaminhamentos aos serviços e programas da rede de políticas públicas, a equipe da SEMSE se depara com dificuldades. A falta de vagas em aberto é considerada um fato comum que impede o acolhimento do adolescente de imediato. Além disso, existem poucas instituições componentes da rede para fins específicos, inclusive voltados ao atendimento especializado de adolescentes, como, por exemplo, "no caso de comunidades terapêuticas para tratamento e internação de adolescentes totalmente comprometidos" (sic). A nível ambulatorial, os exemplos do Hospital Dias, no PRAIA, e do ADOLESCENTRO foram indicados como parceiros diretos que atendem consideravelmente os encaminhamentos de adolescentes em cumprimento de Medida Socioeducativa. Mesmo sob determinação judicial, apresentada com oficio, os adolescentes ficam na fila de espera devido à grande demanda das instituições da rede.

A Assistente Social entrevistada já atuou à frente da PSC e no momento realiza um trabalho indireto, há três anos, exatamente com a rede de atenção ao adolescente no DF por meio de atualização das informações e articulação com essa rede de atendimento. Dos vários encaminhamentos feitos, há a necessidade que as informações passadas aos adolescentes e às suas famílias sejam esclarecedoras e atualizadas, tendo em vista as mudanças ocorridas no funcionamento das instituições, "sempre há mudanças no tipo e nos dias de acolhimento" (sic). Portanto, a atribuição da Assistente Social de atualizar é vista como fundamental, "fico antenada na rede para melhor auxiliar as pessoas atendidas" ( $\mathrm{sic}$ ). O contato com as instituições da "Rede Ativa" é estabelecido por telefone no intuito de atualizar "para saber e entender a respeito dos programas oferecidos pelas instituições e colher informações desde os dias de consultas ao dia do acolhimento" (sic). A importância desse trabalho também se deve ao perfil socioeconômico dos adolescentes e de suas famílias, "porque temos uma população bem carente, então vai acontecer que o encaminhamento será feito pela equipe e se é passada a informação errada e o usuário der 'com a cara' na porta, ele não vai voltar mais" (sic). 
No relato dos psicólogos foi informado que o estudo psicossocial individualizado do adolescente é feito pela equipe da SEMSE por entrevistas ou visita, em alguns casos, na residência do adolescente. Nesta última se verificar o ambiente no qual o adolescente e sua família encontram-se inseridos, ou seja, as condições do local. No entanto, a realização de um estudo mais aprofundado vai depender do caso, quando se sente a necessidade. Para todos os casos, sempre se busca ouvir a família. Portanto, o estudo abrange a família no sentido de averiguar suas possibilidades para ajudar o adolescente em situação infracional. A importância da família é considerada em todos os momentos na PSC. No acolhimento convoca-se alguém da família no primeiro dia para a orientação, a fim dos familiares tomarem conhecimento dos profissionais que "vão tomar conta do filho" (sic) e para que a equipe da SEMSE conheça os respectivos responsáveis. Contudo, o psicólogo afirmou que a PSC não possui a função de promover o vínculo familiar, "isso fica para a LA" (sic). Segundo ele, ainda, a PSC serve "para que o jovem assuma uma responsabilidade de horário, de conduta, para ele saber que existe respeito, respeitar e ser respeitados, já que muitos não são respeitados, e por isso cometem o ato infracional" (sic). Conclui-se, que o enfoque do atendimento na PSC, para este técnico, é centrado no próprio adolescente em sua individualidade.

De acordo com declaração da assistente social, a equipe da SEMSE não se prende ao encaminhamento apenas quando há cumulação com as Medidas Socioeducativas. Busca-se detectar na conversa se o próprio adolescente ou algum familiar possui alguma necessidade para, então, indicar atendimento numa instituição adequada por meio do oficio informal, contendo os dados básicos do adolescente. Foi citada a articulação realizada no âmbito da própria VIJ, através do projeto Anjos do Amanhã que conta com parceiros da rede de atenção no DF, "eles tem convênio com o SENAC, a Microlins, dentre outras instituições" (sic). A função da assistente social, neste contexto, seria prestar suporte de divulgação quando o técnico detecta a necessidade de inserção do adolescente em algum serviço particularizado da rede, por intermédio do repasse da informação atualizada. A dependência química também foi apontada como um problema freqüente apresentado pelos adolescentes, que afeta o cumprimento da medida. Nestes casos, procura-se encaminhá-los para tratamento, apesar de existirem poucas instituições especializadas no DF, a exemplo do COMPI (atendimento até os 18 anos de idade) e do Centro de Atendimento Psicossocial - CAPs. 
Segundo a concepção da assistente social, de forma alguma o atendimento da SEMSE fica restrito à orientação da Medida Socioeducativa de PSC, perpassa entender a realidade conflituosa do adolescente defrontada pela equipe. A inserção do jovem em realidade difícil, de vulnerabilidade, destrincha complicações que os profissionais terminam de orientar sobre a Medida de PSC e já entram em outras questões emergentes. São problemas que "chegam à justiça para que sejam dadas respostas ou feito encaminhamentos" (sic). Há situações que pode arredondar em estudos de casos profundos, no intuito de entender melhor a situação vivenciada pelo adolescente e, assim, ser indicado encaminhamento mais adequado a fim de sanar ou minimizar os agravantes. Então, cria-se um vínculo com o adolescente e seus responsáveis, no qual os familiares entram em contato com a equipe e procuram suporte, avisando as dificuldades que impedem o adolescente de comparecer nos locais de cumprimento da Medida, por exemplo. "O envolvimento da equipe SEMSE na PSC é bastante, tendo em vista sua execução ocorrer na VIJ/TJDFT" (sic).

Vislumbrando a intenção de garantia de continuidade e visualização dos impactos da PSC, os três entrevistados membros da equipe da SEMSE confirmaram não haver acompanhamento ao adolescente pós-cumprimento de Medida Socioeducativa. Segundo um psicólogo, essa função seria de responsabilidade dos locais de atenção às Medidas Protetivas aplicadas paralelamente. Como técnicos, a equipe da Medida Socioeducativa de PSC vê a necessidade e encaminha aos serviços da rede de Medidas Protetivas, mas a continuidade do atendimento vai depender da necessidade atrelada ao interesse do adolescente. Diferente dos casos de LA, onde o adolescente é acompanhado pelo menos durante seis meses e obrigado a estudar, na PSC ele se quer tem a obrigação de estar matriculado na escola. No entanto, quando a equipe da SEMSE detecta esta carência, se tenta insistir e convencer o adolescente da importância dos estudos, porém não há um acompanhamento que verifique como se dá a inserção deste adolescente junto à escola. Portanto, o contato da equipe SEMSE com o adolescente é restrito ao tempo de cumprimento da Medida, sob o vínculo institucional. No processo de aplicação da PSC, sempre há retorno das instituições que acompanham os adolescentes, mas depois dos desligamentos perde-se o contato com eles. De acordo com a equipe, a VIJ não tem condições de fazer um acompanhamento posterior, pois o trabalho de execução assumido por eles é intenso, já atendem outros adolescentes em seguida conforme a rotatividade da grande demanda, apesar do interesse em ter esse contato pós. 
A avaliação consensual dos profissionais da SEMSE quanto ao desempenho do trabalho de execução da PSC é de que acontece no limite do tempo de cumprimento da Medida. Há o reconhecimento de que com o pós-cumprimento a Medida seria bem mais abrangente. A partir da visão da PSC como um espaço de oportunidades, o outro psicólogo entende que na Medida o adolescente inicia e desenvolve uma prática profissional. Portanto, seria importante "dar continuidade ao adolescente, aproveitar a motivação, o bom desempenho" (sic). Contudo as tentativas de acesso na área do trabalho, por exemplo, não foram exitosas. Nesse sentido, houve uma fase de premiação de adolescentes que obtiveram bom desempenho nos serviços executados na PSC, com a seleção de fichas desses jovens destaques, para tentar inseri-los como estagiários junto à CEB - Companhia Energética de Brasília. Apesar da preocupação quanto à inserção do adolescente no mercado de trabalho, as propostas não foram adiante.

Mesmo sem o compromisso de acompanhamento do adolescente posterior à Medida, a assistente social relatou sua vivência como integrante da comissão de PSC em reunião final de prestação de serviços na AVHUB, onde os retornos foram muito positivos quanto ao impacto da Medida. "Os adolescentes, no geral, iniciam a Medida com muita raiva, mas depois, quando entram em contato com a Medida, gostam muito" (sic). Inclusive, já houve casos em que os adolescentes tiveram interesse em continuar nos locais de serviço como voluntários, tanto por terem gostado das tarefas executadas como por terem criado vínculo com os coordenadores e entre o próprio grupo de adolescentes, pertencentes às várias classes sociais e unidos pela mesma situação, favorável à integração social.

A equipe também atendeu ocorrência de pais de adolescentes de classes média/superior que solicitavam o afastamento dos filhos das "más influências" (sic) que os garotos mais pobres representavam. No intuito de barrar o preconceito, os pais eram esclarecidos de que o atendimento estabelecido considera como igual o nível de posição dos adolescentes em função do fato comum entre todos, de cometimento do ato infracional, independente da renda. Também se registrou ocasião de pais pedindo a conversão da Medida em pagamento de cesta básica, ainda pelo receio do adolescente se "misturar" com o grupo de risco. Mesmo com os preconceitos internos entre os adolescentes, inclusive do jovem em condições menos favoráveis em relação aos mais 
ricos, com a conclusão da Medida observava-se "vínculos de amizade estabelecidos, mesmo sem acompanhamento posterior" (sic).

Concluindo as reflexões sobre o contexto acima apresentado, relacionado à aplicação da PSC e a articulação com a rede de atenção ao adolescente desempenhada pelo trabalho da SEMSE, as considerações feitas permitem identificar a distinção entre acompanhamento $\mathrm{X}$ encaminhamento às instituições da rede. Em sua rotina de procedimentos, a SEMSE realiza o acompanhamento do adolescente fundamentalmente na Medida Socioeducativa, enquanto são indicados apenas encaminhamentos de cunho Protetivo, ou seja, sem o compromisso de acompanhamento por parte da SEMSE/VIJ. Nesse ponto, não há retorno quanto ao destino dos encaminhamentos, tendo em vista que as Medidas Protetivas deveriam ser acompanhadas pelo Conselho Tutelar.

Ao término do cumprimento da Medida Socioeducativa de PSC os autos são arquivados, então a SEMSE não tem conhecimento se o adolescente cumpriu a Medida Protetiva $^{56}$. Exceto nos casos em que a instituição retorna a incompatibilidade de atender este jovem (por critérios como a idade, por exemplo), é passado juiz que retorna o pedido à SEMSE para que o adolescente seja inserido em outra instituição capaz de atendê-lo. No entanto, não há um acompanhamento de perto da SEMSE, apenas em poucas ocasiões em que se estabelece contato com os pais, para saber se o adolescente compareceu ao local indicado. Então, os técnicos entrevistados entendem que o atendimento é, "com raras exceções" (sic), centrado nas Medidas Socioeducativas.

A assistente social revelou uma proposta sugerida pela equipe da SEMSE de criação de outra seção responsável direta que acompanhasse a aplicação das Medidas Protetivas. Reconhece-se a necessidade de um acompanhamento simultâneo tanto da Medida Socioeducativa quanto da Protetiva, já que acontecem num mesmo momento sob determinada situação infracional. No entanto, o trabalho da SEMSE/VIJ tem se preocupado apenas com o esforço de encaminhamento às instituições e serviços de proteção ao adolescente disponíveis na rede de políticas públicas do DF. O acompanhamento da PSC é o foco que mais interessa para a equipe da SEMSE, para

\footnotetext{
${ }^{56}$ Quando o juiz decide por aplicação somente de Medida Protetiva, o adolescente é encaminhado direto para o Conselho Tutelar, e logo se arquiva o processo.
} 
fechar com o adolescente sua pendência com a justiça, no processo de cumprimento da Medida Socioeducativa. Segundo a assistente social, se há encaminhamento compete à própria instituição da rede dar um retorno ao juiz, responder a detalhes do atendimento. “Os autos não deixam de ser arquivados por pendências no cumprimento de Medidas Protetivas" (sic). Já a resposta da Medida Socioeducativa é exigida e realizada pela SEMSE para que o adolescente seja liberado e o processo revogado. Percebe-se no processo de operacionalização da PSC uma leitura fragmentada da Medida Socioeducativa em seu aspecto protetivo, que é parte integrante da Medida.

Diante das dificuldades em estabelecer vínculo de convênio com instituições parceiras, bem como em adaptar no trabalho de execução o acionamento da rede de políticas públicas em paralelo ao cumprimento da PSC, uma questão foi levantada pela assistente social com relação ao papel da VIJ: "como ser fiscalizador sendo executor ¿" (sic). Tal contradição também afeta a estrutura de funcionamento da PSC. Como representante do poder jurídico, a SEMSE/VIJ foi criada em sua origem com o objetivo de fiscalizar o andamento das Medidas Socioeducativas. Segundo a entrevistada, o momento atual de transição de responsabilidade institucional para a SEJUS, como órgão executivo das Medidas Socioeducativas, se apresenta um marco oportuno inclusive na perspectiva de facilitar o trabalho articulado em redes por encontrar-se no âmbito do Governo do Distrito Federal (GDF). Há muitos órgãos do GDF capazes de assumir o compromisso de trabalho Socioeducativo, ressalvada a importância de ampliação de instituições com vistas à proximidade da comunidade da qual o adolescente pertence, que hoje é dificultada devido aos poucos convênios firmados. Sendo assim, "o papel das instituições ficará mais claro" (sic). Deste modo, a VIJ deixará de encaminhar o adolescente no primeiro contato, no atendimento, mas continuará a atender nas entrevistas de admoestações, quando ele deixa de cumprir.

Um psicólogo expressou o posicionamento de que a necessidade de articulação com a rede de políticas publicas é de importância suma, por entender que o ato infracional cometido ocorreu pela falta da inserção dele em qualquer uma das frentes de políticas. No entanto, para a PSC o enfoque parte do investimento em outros aspectos antes da intervenção de acesso às políticas, seria no "despertar do jovem e seu interesse, no estímulo, na dedicação dele em casa, com a família, em valores como assumir as atividades diárias, dividir as tarefas de casa..." (sic). No caso da PSC, a assistente social 
comentou que não é preciso muito recurso para a execução desta Medida. Com a mudança institucional, a SEMSE se dispôs a prestar auxílio no treinamento dos tutores, que no caso seriam os próprios servidores do GDF, "sem necessidade de mobilização de recursos ou materiais grandiosos" (sic).

\subsection{2 - Equipe de Coordenadores dos locais de cumprimento da PSC}

\subsubsection{1 - AVHUB}

A coordenadora responsável pela execução da PSC na AVHUB possui formação acadêmica na área de enfermagem e psicanálise clínica, além de especialização em psicoterapia e psicopatologia. No momento, cursa o $4^{\circ}$ período de Serviço Social na UNITINS. Seu vínculo com AVHUB foi firmado há três anos, quando trouxe uma paciente para receber atendimento no HUB e teve muita dificuldade, onde acabou conhecendo um voluntário da AVHUB que prestou assistência. Quando se engajou na associação, já existia o cumprimento de PSC no local sob a responsabilidade de outro coordenador que logo a convidou para trabalhar desta frente, considerando sua formação de psicanalista e sua experiência em clínica própria. A entrevistada informou assumir a coordenação do projeto neste ano de 2009 e prefere se referir aos adolescentes como "menores carentes", ao invés de menores infratores.

Quanto ao conceito de Socioeducativo, a declarante expressou sua opinião de que a Medida de PSC é falha porque deveria ser mais educativa. Como os sujeitos que acompanham diretamente os adolescentes são voluntários (coordenadores e tutores) é passado a eles tudo aquilo que os envolvidos gostariam de fazer. Portanto, a dinâmica de execução da Medida é pessoal, independente de uma proposta pedagógica comum e sem diretrizes de ação a serem aplicadas. Outra preocupação que deveria ser investida é a associação dos pais no processo de cumprimento da PSC, "considerando a existência do fator causador da situação infracional ser de responsabilidade em no mínimo de 50\% dos pais dos adolescentes" (sic), envolvimento que deveria ser determinado inclusive pelo juiz. De acordo com sua análise, a aplicação da PSC também carece de mais apoio, inclusive institucional. Para ilustrar tal problemática, ela comentou um exemplo de ocasião em que foi negado pedido de liberação de almoço para os adolescentes no HUB.

A partir da visão de que o trabalho da Medida não é procurar culpados e sim a solução dos agravantes que impulsionaram o envolvimento do adolescente na situação 
infracional, a entrevistada tem claro que a conduta ocasional do adolescente não é inata à sua personalidade. Ela considera possível e importante que a sociedade pratique formas dos outros adolescentes não chegarem a cometer atos infracionais, no sentido da prevenção. “A intenção da Medida não é, portanto, punir um garoto de 13/14 anos do qual não se tem conhecimento de sua história" (sic). Na dinâmica de cumprimento da PSC no HUB, o adolescente presta serviços internos de Office boy, transportando papéis e documentos.

A didática Socioeducativa desenvolvida por ela acontece através de reuniões terapêuticas onde se perguntam aos "garotos" (sic) sobre sua história de vida. Estas reuniões acontecem um dia na semana, durante as terças-feiras, quando o trabalho de unir os jovens serve de apoio psicológico aos mesmos. Nota-se nas terapias a influência do ambiente familiar desestruturado como problema gritante em suas formas de expressão. A figura paterna é bastante citada com ressentimentos, "de 12 meninos, penas 2 têm pai. Muitos dizem que nunca viram o pai, que o odeia, que o pai não existe" (sic). Na intervenção psicoterápica junto ao adolescente, procura-se ao máximo incentivar o perdão, buscando compreender a história dos pais e mostrar que a falta de cuidado e dedicação deles é reflexo das condições em sua juventude.

O trabalho de conversação e escuta desenvolvido nas reuniões desperta o potencial do adolescente por representar um espaço livre de expressão, "tem uns que falam muito, outros choram, outros não falam" (sic). Também é incentivada a expressão através dos desenhos, desenvolvida ao longo das reuniões ${ }^{57}$. Os desenhos ilustram histórias tristes, que os adolescentes não conseguem falar. Como os desenhos vão mudando com o passar da Medida, os psicoterapeutas objetivam realizar um estudo analítico. Houve o caso de um adolescente, de características rebelde e introspectivo, desenhar uma arma. "Na última reunião ele não desenhou a arma" (sic), o que representou uma mudança de valores e do modo como ele enxerga a vida, desenvolvido na PSC.

A entrevistada considera como falha do governo a falta de investimento e assistência às Medidas, bem como a insuficiente diversidade de recursos humanos, "se

\footnotetext{
${ }^{57}$ No decorrer da entrevista a pesquisadora teve acesso aos desenhos produzidos pelos adolescentes. Havia muitas ilustrações ofensivas, pertencentes ao universo dos jovens, como armas, folhas de maconha, letras em forma de pichação, entre outros.
} 
tivessem mais profissionais, assistentes sociais, psicólogos, para atender tantos os filhos quanto os pais, seria um trabalho profilático" (sic). Desta forma, a amplitude do atendimento psicossocial poderia abranger todos os membros da família do adolescente, e "aquilo que aconteceu com um filho de treze anos, não aconteceria com o filho de três, porque aquela família já estaria recebendo uma ajuda lá do começo" (sic). Com relação à estrutura física oferecida, por exemplo, a AVHUB não possui sala específica para o atendimento da Medida Socioeducativa, fato que impede a realização de uma estratégia de intervenção direcionada à família.

A AVUB dispõe de recursos financeiros advindos de arrecadações angariadas no bazar permanente instalado no HUB e provenientes de festas promovidas pela comissão responsável da associação, além de doações. Os envolvidos na AVHUB, inclusive a equipe responsável pela Medida de PSC, possuem vínculo de voluntários, portanto não são remunerados e, por muitas vezes, ainda tem que colaborar com as despesas da associação. Além dos voluntários, as parcerias estabelecidas pela AVHUB são de cunho financeiro. Por exemplo, há supermercados que doam suprimentos para eventos da associação, como um jantar dançante, para arrecadarem fundos.

A coordenadora declarou não ter participado de capacitação alguma ao longo de sua atuação junto à PSC, não teve notícia de nenhum evento oferecido no sentido de formação e aprofundamento, “o máximo que acontece são reuniões com a VIJ” (sic). Revelou desconhecer o SINASE, bem como não desempenhar um trabalho articulado com a rede de atenção ao adolescente disposta no DF. Comentou, ainda, a respeito da exigência no contrato entre a AVHUB e a VIJ de não receber adolescentes dependentes, o que corresponde à determinação da direção do HUB. No entanto, a equipe tem consciência de que muitos adolescentes são usuários de drogas.

Quanto à questão da garantia de acessibilidade ao adolescente, a entrevistada avalia que no tempo máximo de seis meses de contato com o adolescente, referente ao cumprimento da PSC, não é possível efetivar encaminhamentos ao passo que não se identificam necessidades especiais dos adolescentes, apenas percebem-se carências de ordem básicas. Muitas vezes fornecem dinheiro para passagem e para lanches. Quando se detecta um caso mais grave de indisciplina o procedimento é encaminhar para a VIJ, conforme determinação/orientação. Sendo o HUB um espaço no âmbito da saúde, aconteceram acasos em que o adolescente apresentou mal-estar durante o cumprimento, 
daí então ele é encaminhado ao atendido no ambulatório e pode ser dispensado diante de atestado médico. Como entendedora de psicopatologia, a declarante disse que se caso identificar algum necessidade ou comprometimento desta ordem, procede informar ao conhecimento da VIJ para que sejam tomadas as medidas cabíveis.

Questionada a respeito do contato posterior à Medida com o adolescente, a entrevistada declarou tentar ao máximo, através das fichas dos jovens, manter ligações. Segundo ela, pretende-se conseguir mais voluntários no intuito de consolidar um serviço voltado à realização de visitas às famílias, verificar se estão inseridos em algum projeto ou trabalho social. Sua conclusão sobre a PSC é positiva, no sentido da providência dos serviços exigidos, mas deveria ser mais acessível, ou seja, ter mais consistência em sua operacionalização com vistas a expandir a atenção ao jovem e, assim, atingir seu contexto familiar. Utilizando de comparações, a entrevistada considera como eixo fundamental a intervenção ampliada da PSC junto à família do adolescente: "a febre é conseqüência de um fator causador, uma inflamação. O tratamento é feito com antibiótico para a garganta, para eliminar a causa da febre. Então, não adianta punir/educar o adolescente se ele encontra-se inserido numa família com dificuldades, ele pode até reincidir" (sic). Equipara, ainda, com a situação do dependente químico, "se ele volta para uma família que continua desestruturada não só financeiramente, mas emocionalmente, e volta ao convívio com amigos dependentes, ele retornará a ser dependente" (sic).

\subsubsection{2 - PeSC/UnB}

Já no PeSC/UnB, a coordenadora em lócus da Medida de PSC possui formação acadêmica em Serviço Social, especialização em Psicologia Transpessoal e Terapia Comunitária. Ela encontra-se vinculada à UnB na condição de prestadora de serviço há onze anos, ou seja, sem vínculo empregatício, desempenhando cargo de assistente social junto à Diretoria de Desenvolvimento Social (DDS). Seu engajamento com a PSC ocorre desde o ano de 2004, momento em que o projeto ficou parado com a saída de sua fundadora (pedagoga), quando a entrevistada foi convidada pela DDS a dar continuidade ao PeSC.

De acordo com a visão da entrevistada, a antiga coordenadora se articulava muito bem, mas não contava com uma equipe para dar continuidade à dinâmica da 
Medida. Os participantes não tinham noção do papel representado por eles e da real função da PSC sobre a influência na vida do jovem. Portanto, faltava compromisso dos atores envolvidos na execução da Medida que acabavam se afastando do projeto.

O preparo para a recepção dos adolescentes exige da equipe do PeSC um levantamento de número de vagas disponíveis nos setores da UnB que é passado para a VIJ. Cabe à VIJ fazer a distribuição dos adolescentes de acordo com o perfil dos $\operatorname{mesmos}^{58}$. Atribuição antes realizada pelo PeSC, foi percebida a dificuldade na identificação de perfis por conta da falta de contato anterior com os adolescentes para verificar suas características e habilidades. Então, por terem mais condições devido ao acompanhamento inicial, fica a encargo da VIJ realizar a divisão dos adolescentes aos locais de serviços segundo seus perfis.

No acolhimento do PeSC/VIJ com os familiares, é feita a recepção direta aos adolescentes e, neste momento, se busca mostrar a importância da família no processo de cumprimento da Medida. A VIJ passa ao projeto a lista com os adolescentes e os lugares já encaixados, no entanto não são repassadas as análises de perfis. Sobre a qualidade dos serviços disponíveis, a entrevistada comentou que "como o nível escolar dos adolescentes é bem pequeno, então os trabalhos são de acordo. São serviços manuais, mais ligadas ao fazer. Serviços que envolvam o intelectual, o administrativo, não importam muito" (sic). Nesta reunião de acolhimento, realizam-se duas dinâmicas para descontrair, tendo em vista a exposição que o ato infracional do adolescente repercute, então, a família atravessa uma situação difícil. A dinâmica da rede social representa a oportunidade dos pais dos adolescentes se expressarem. Já a dos círculos serve para que eles visualizem a integração na Medida, na idéia de que tudo tem que funcionar junto. Também é feito o encaminhamento e fornecida uma agenda com todos os dias que ele deverá prestar os serviços, numa carga máxima semanal de oito horas como garantido no ECA (Art. 117, P.U., 2005).

A entrevistada falou que o conceito de "Socioeducativo" precisa ser alcançado, ou seja, não é desempenhado em sua plenitude atualmente. Conta com a disponibilização das pessoas para participarem, unirem-se para resgatar as situações dos adolescentes. "É uma coisa cultural, que deve ser plantada" (sic). Mas sobre o PeSC, ela

\footnotetext{
${ }^{58}$ Assim como definido no ECA, "as tarefas devem ser atribuídas conforme as aptidões do adolescente". (Artigo 117, Parágrafo único, ECA, 2005, p. 32).
} 
reconheceu que a UnB conta com funcionários de vários setores que entendem a importância da oportunidade que a PSC oferece. Entendem que a situação socioeconômica e cultural dos adolescentes é muito difícil, lhes faltam acesso e oportunidades. Portanto, "trata-se de uma dívida social realmente" (sic).

No PeSC faz-se o acompanhamento dos adolescentes nos setores, quase diário, por conta da dificuldade relativa à distância, pois moram longe, e por não estarem bem conscientes do que significa a PSC. A coordenadora desenvolveu dinâmicas aplicadas em oficinas Socioeducativas, com a criação de espaço onde se procura dá oportunidade do adolescente vê sua própria história e resgatá-la. Partindo do princípio de que o adolescente deve ter toda uma estrutura psicológica para cumprir a Medida, as oficinas têm o enfoque muito "nele próprio, nas capacidades que ele tem, nas inteligências, nas habilidades, para que ele descubra os talentos, os dons que possui e certa afinidade, seja de conversar com as pessoas, seja de vender, seja de construir algo. Estimulá-lo para que ele venha alcançar alguma coisa" (sic).

A base pedagógica desenvolvida nas oficinas é feita a partir da figura de uma árvore, que vai sendo construída com suas partes e seus respectivos significados. $\mathrm{O}$ tronco representa o adolescente, as raízes os antecedentes (familiares, pais, avós) e tudo que essas pessoas conferiram para ele (valores, concepções de vida), seria a rede de apoio social que começa desde a família. A sociedade é representada pelos galhos que partem da copa do tronco, quer dizer, o próprio adolescente constrói a rede social para ele se desenvolver. Outra dinâmica das inteligências destaca-se por mostrar os vários tipos de inteligências que identifica o diferencial de cada um, o que dá suporte e determina o papel de adolescente/cidadão social. Os frutos da árvore representam os resultados do trabalho para a sociedade, no que o adolescente pode contribuir para ajudar a construí-la. "É o servir, é o participar desta construção, essa consciência tem que ser plantada e valorizada" (sic).

Sobre a questão das parcerias, a coordenadora aponta como vínculo e reconhecimento importante o registro no Conselho da Criança e do Adolescente, que se interessa pelo projeto e visita os locais de prestação de serviço na UnB. Os Decanatos de Assuntos Comunitários e de Extensão da UnB também apóiam o projeto que é cadastrado nos respectivos, além dos locais de cumprimento de serviços da Medida, como exemplo a Biblioteca Central dos Estudantes que recebe de seis adolescentes por 
turma. Em outro campo, no Instituto de Química, os adolescentes começaram com serviços de limpeza do local sob a supervisão do tutor, mas percebeu-se que eles tinham habilidade com informática. Um jovem se destacou com serviço de informática por produzir um slogan para um evento internacional e, assim, se sobressaiu. Nota-se que os parceiros que constituem a rede de instituições envolvidas com a aplicação da PSC na UnB se restringem aquelas necessárias em seu mínimo para a viabilidade do cumprimento da Medida Socioeducativa, essencialmente os locais de serviços dentro do próprio campo.

Segundo depoimento da coordenadora Socioeducativa do PeSC, os recursos disponíveis não são suficientes para efetivar um trabalho consistente. Com relação à estrutura, um espaço próprio seria necessário e fundamental para o atendimento ao adolescente e sua família, bem como o desenvolvimento de atividades Socioeducativas $^{59}$. Colocou, ainda, que o PeSC tem se apoiado nos bolsistas que tem se interessado pelo projeto e gostam de fazer o trabalho, mas não há continuidade por se tratar de estudantes da universidade. Eles se desvinculam ao projeto, por se formarem, ou por outros motivos acadêmicos. Neste ano o projeto não recebeu adolescentes, a coordenadora ficou disponível para um curso de capacitação promovido pela SEJUS em parceria com a UnB. Neste período de aprofundamento, ela pretende escrever sobre o projeto para manter uma produção impressa registrada, além de incrementar as oficinas por meio de pesquisas. "Quero utilizar filmes e músicas, porque a aproximação com os adolescentes deve ser estabelecida de maneira diferente, criativa, para estimulá-los" (sic). Ela entende que a dinâmica de abordagem pedagógica junto ao adolescente deve possuir conteúdo próximo ao universo dele, a partir do que ele conhece.

Ainda a respeito do envolvimento em capacitação, a entrevistada revelou que já participou de algumas, como um curso oferecido pela Faculdade de Educação (FE) para os tutores da PSC que foi aberto a toda a população. Segundo ela, este evento foi direcionado para a temática da adolescência, no geral, com embasamentos no ECA e contribuição de profissionais das áreas de Educação e Serviço Social. Com relação ao conhecimento das diretrizes do SINASE, ela afirmou está tendo contato com este

\footnotetext{
${ }^{59}$ O espaço físico do PeSC, oferecido pela UnB, encontra-se numa sala aberta, compartilhada com outros funcionários da DDS, sem separação que garanta privacidade no atendimento. Dispõem de poucos recursos administrativos e financeiros para a promoção de materiais e incrementos às oficinas, necessitando de parcerias que contribuam financeiramente (FINATEC, por exemplo).
} 
material no curso de capacitação referido anteriormente. Neste curso de capacitação, no momento está sendo discutido o enfoque das Medidas de privação de liberdade. "Mas o incentivo é sobre as Medidas em meio aberto, para se evitar a internação e promover a participação da sociedade" (sic).

Neste discurso a declarante enxerga a articulação da PSC com a rede de atenção ao adolescente disposta no DF como fundamental, "porque o q mais dói é ver que a equipe faz tudo que está ao alcance, mas não se sabe qual o apoio que o adolescente vai ter lá fora" (sic). No acesso à educação, cultura, lazer, saúde do adolescente, as instituições da rede "devem contar uma com a outra para, assim, funcionar muito bem" (sic). Foi feito um destaque sobre a necessidade de mudanças nas instituições de ensino, com incorporação de um novo paradigma, no qual os professores sejam preparados para atuar e passar a idéia de que crianças e adolescentes são os protagonista de suas histórias, incentivando a participação do adolescente no processo de construção da sociedade. "Não adianta passar conhecimento teórico sendo que o adolescente não tem interessa devido às suas condições socioeconômicas que são complicadas” (sic).

Concluindo, a entrevistada avalia que no trabalho de execução da PSC há pouca articulação com a rede de políticas públicas. Reconhece que, apesar das equipes acreditarem na Medida e demonstrarem empenho, também deve haver um incentivo à participação por parte dos outros integrantes da rede de atenção ao adolescente, para dar continuidade aos casos de proteção tanto do adolescente que passou pela Medida Socioeducativa quanto de sua família. Atualmente, ela não vê uma política que possa suprir a garantia dos direitos básicos do adolescente, "muita coisa tem q ser construída, falta estabelecer como prioridade" (sic). No processo de cumprimento da PSC na UnB não há um acompanhamento posterior à Medida por falta de estrutura, de acordo com a entrevistada, "só em termos de pesquisa" ${ }^{60 " ~(s i c) . ~ A ~ n e c e s s i d a d e ~ d e ~ u m a ~ p o l i ́ t i c a ~ q u e ~}$ mobilize todos no limite do tempo de cumprimento, seis meses, é um desafio que deveria ser mais investido, por mecanismos de troca de informações e atualizações dos serviços disponíveis na rede de políticas públicas.

\footnotetext{
${ }^{60}$ Já houve produções de monografias onde o campo foi estudado e avaliado em seus impactos, junto ao adolescente e à família. Ver o exemplo de SANTOS, Dirce Abadia de Faria. "Prestação de Serviços à Comunidade: Medida Socioeducativa que contribui para a (re)inserção social do adolescente infrator ¿", UnB, 2000.
} 


\subsubsection{SEJUS/DHC}

No intuito de complementar a análise da pesquisa, realizou-se entrevista semiestruturada com um funcionário da SEJUS, engajado na aplicação da Medida Socioeducativa de Semiliberdade em Taguatinga, por entender como necessário compreender o atual contexto de mudança de responsabilização organizacional da PSC. Segundo ele, a transferência ocorreu sem nenhuma discussão inter ou intra-institucional, além de ter sido transpassada legalmente entre secretarias do Poder Executivo do Distrito Federal, ou seja, da Secretaria de Desenvolvimento Social e Trasferência de Renda (Sedest) para a SEJUS. De acordo com suas informações, até o dia 31 de dezembro de 2006, as Medidas Socioeducativas estavam ao encargo da Sedest, sede da SEJUS. No dia 01 de janeiro de 2007, essas Medidas foram transferidas para a SEJUS, sem que houvesse prévio debate crítico que fundamentasse o planejamento funcional da aplicação das Medidas Socioeducativas sob a nova gestão.

Com a mudança de secretarias, a VIJ/TJDFT continua exercendo junto às Medidas Socioeducativas seu papel de fiscalização e normatização que cabe ao judiciário. De acordo com o entrevistado, a discussão antiga que se estende no caso das Medidas Socioeducativas está relacionada à dificuldade de localização das mesmas no âmbito das políticas públicas, se inserem nos direitos humanos ou na assistência sociali No DF, a situação de meninos de rua e meninos em conflito com a lei acabava sob responsabilidade da política de Assistência Social. Segundo informações do declarante, o máximo de estrutura que a secretaria de Assistência Social teve foi uma gerência, formada por um equipe com três funcionários sendo um gerente, um assistente e dois técnicos, para atender as internações, as semiliberdades (5 casas) e as LAs (14 unidades). Neste novo governo, abriu uma subsecretaria e, posteriormente, caiu para uma coordenadoria, ou seja, ocorreu um retrocesso a nível de status representativo. Deveria haver no mínimo uma secretaria, um órgão específico, com estrutura suficiente para atender toda a demanda das Medidas Socioeducativas, bem como a existência de um plano de carreira para os profissionais que executam as Medidas Socioeducativas considerando o nível de violência que aumenta a cada ano, por conseqüência o crescimento de adolescentes envolvidos em atos infracionais. "Esta secretaria deveria ter uma estrutura capaz de atender à altura das especialidades da demanda" (sic). 
Considerando que o governo realizou a transição de secretarias de forma aleatória, a incerteza que circunda a localidade política das Medidas Socioeducativas não tem definição porque é elas foram institucionalizadas historicamente há pouco tempo, sob indicação do ECA em 1990, e no DF coube a assistência social aplicá-las. Como os adolescentes em cumprimento de Medidas estão mais associados à situação de falta de garantia de direitos, o GDF entende que compete à assistência social lidar com intervenções em casos de crianças e adolescentes vítimas de vulnerabilidades. Já em outros Estados do território brasileiro, a execução das Medidas Socioeducativas está ligada à secretaria de educação, por exemplo, segundo uma interpretação de proximidade de características. O entrevistado defende que cabe à secretaria de direitos humanos assumir a operacionalização das Medidas Socioeducativas. "Acho que não corresponde somente à assistência social, ela tem um papel fundamental no atendimento a meninos sobre Medida, mas tais quais as políticas de educação, de saúde, de trabalho, do esporte cultura e lazer, entre outras, é uma questão de garantia de direitos." (sic).

A partir do entendimento das Medidas Socioeducativas como um braço dos direitos humanos, na área federal elas já estão inclusas nas áreas dos direitos humanos, antes pertencente à secretaria de justiça. Então, no DF a tendência é firmar as Medidas Socioeducativas na secretaria/política de direitos humanos. Quanto ao empenho da SEJUS em consolidar uma política eficiente que permita o bom funcionamento do Sistema Socioeducativo, foi informado que neste ano de 2009 foi promovido um curso de capacitação voltado para 600 servidores, profissionais da internação, semiliberdade e LA, de nível médio e superior. O entrevistado declarou que no momento o curso conta com a participação de 300 servidores, ou seja, teve 50\% de evasão. A proposta do curso é a criação do Projeto Político Pedagógico (PPP), que será a diretriz maior para a execução das Medidas. Este PPP está sendo elaborado a partir dos fundamentos do SINASE, através da colaboração coletiva dos atores envolvidos no referido curso.

Fora isso, de 2003 até 2006, a SEJUS havia implementado na prática um programa de Medidas Socioeducativas que, dentro deste havia três projetos - um para internação, outro para semiliberdade e outro para LA. Como ramificação destes projetos havia serviços diversos que completavam o atendimento Socioeducativo. Então, a estrutura era formada por programa, projetos e serviços. Com a mudança de governo, esta idéia foi extinta e, até agora, a SEJUS funciona sem planejamento ordenado, “com 
base na cultura do automático" (sic). Portanto, hoje as atividades são baseadas na cultura, nas diretrizes antes oficializadas pelo programa citado, que não recebe mais investimentos e recursos.

Segundo o entrevistado, a SEJUS tem ciência do dever de assumir a responsabilidade da PSC, que está sendo executada pela VIJ. Mas o plano é efetivar a mudança a luz da nova proposta do PPP que está sendo elaborada no curso de capacitação. "Quem sabe a PSC seja executada pelas equipes de LA, o plano é este já que se tem uma estrutura formada com as equipes de LA, com psicólogos, assistentes sociais, educadores...” (sic). Antes da institucionalização do ECA, vários juízes tinham a vocação de ser executivo e assumiam a execução das propostas Socioeducativas. $\mathrm{O}$ papel deles era de fiscalização e normatização, mas os juízes de Brasília começaram a executar PSC. Por outro lado o poder executivo, o governo, ficou quieto, omisso. Não se esforçava com dispêndio de recursos e obtinha um ganho secundário. Isso vem se prolongado até hoje. Então, o maior responsável é o GDF que não assumiu o compromisso de execução, apenas se conformou com a atuação do juiz.

De acordo com esclarecimentos do declarante, quando ele trabalhava na gerência da secretaria, adequaram a proposta de atendimento Socioeducativo ao SINASE, antes mesmo de sua aprovação na câmara, pois suas diretrizes já eram conhecidas quando aprovadas pelo CONANDA. Já estavam preparando o atendimento do Sistema conforme o SINASE e neste plano juntava LA e PSC, seria chamado "projeto de meio aberto" (sic). Adequação do que está previsto no ECA, a criação de um colegiado gestor com um representante de cada setorial de governo (saúde, educação, assistência, cultura...), para a partir daí ditar diretrizes, programas, serviços, foi desenvolvida. A esta proposta dar-se o nome de SIDASE, Sistema de Atendimento Socioeducativo do Distrito Federal. O SINASE é uma proposta nacional. A nível de execução, o SIDASE serviria para aplicar as medidas voltadas a realidade espacial do DF. Na década de 90 existia uma proposta semelhante ao SIDASE, se chamava SASE (Sistema de Atendimento Socio-Educativo em 1992), foi uma proposta do GDF que não saiu da VIJ e nem da área federal. O SASE foi uma proposta do GDF, ligado ao CDCA (Conselho de Direitos da Criança e do Adolescente (ainda em formato de colegiado com representes de cada secretaria), que hoje corresponde ao SINASE e funcionou por um 
tempo. O SIDASE prevê os benefícios de todas as setoriais de políticas para todas as medidas, inclusive a PSC que deverá ser executada junto à LA.

A SEJUS havia proposto um plano bianual entre 2007 e 2009, aprovado em 2006 pelo CDCA e pelo Conselho Nacional dos Direitos da Criança e Adolescente, com a possibilidade de captação de recursos, que previa uma estrutura em forma de diretoria ligada às Medidas em meio aberto e outras diretorias ligas distintamente a semi e à internação. Houve um aumento de instituições de internação, o que representa um retrocesso do cenário Socioeducativo no DF, estamos indo na contra-mão na medida em que se valoriza e as medidas de privação de liberdade enquanto se deveria fortalecer as medidas em meio aberto, ou no Maximo a semiliberdade. A interação, com as instituições formadoras da rede de políticas publicas, acontece de forma invertida. "A gente tem que ficar pedindo a eles como se fosse um favor os serviços solicitados, considerando a própria precariedade da estrutura das políticas que dificulta principalmente o atendimento de quem comete ato infracional" (sic). A intenção é de que estas políticas públicas elaborem ações definidas, com recursos próprios, destinadas aos adolescentes em situação infracional de maneira digna. O governo federal tem condições de arcar, tem recursos, só não conta com projetos para investir e, por isso, não libera o recurso, que fica parado. $\mathrm{E}$ as equipes de execução das Medidas Socioeducativas ficam numa situação de mendicância, pedido favores aos serviços de políticas públicas.

Como atuante da Semiliberdade, o entrevistado acredita que esta Medida possui maior potencial de transformação/formação, de uma conquista cidadã. O adolescente tem a possibilidade de conviver com a comunidade, ele é livre, tem liberdade de expressão. A Semiliberdade foi pensada como uma casa na comunidade. O espaço atual da casa de semiliberdade em Taguatinga era um antigo Centro de Desenvolvimento Social (CDS), que a SEJUS começou a atender meninos de rua. Não conseguiam casa para alugar nos casos de adolescentes autores de atos infracionais por dificuldades impostas e resistência da comunidade, inclusive com manifestações, como abaixo assinado, no intuito de impedir a instituição da casa de semiliberdade em meio ao bairro. A participação social não é entendida e aceita no caso de situação infracional. $\mathrm{O}$ desafio é mais amplo, é mudar a cultura correcional repressiva para uma cultura cidadão, de direitos humanos. "Hoje a cultura ainda é repressiva, você errou tem que 
pagar" (sic). Mas a idéia vai além da punição, é a necessidade de transformação que vai assegurar ao adolescente cidadão não cometer erros, como sugere o SINASE.

A finalidade da socioeducação não é recuperar o adolescente, e sim torná-lo um sujeito cidadão, consciente, autônomo, trabalhar o protagonismo dele para que seja solidário e competente. A Socioeducação é baseada na idéia de DELOIRS: aprender a APRENDER, aprender a CONVIVER, aprender a FAZER e aprender a SER. Como o tempo de intervenção no cumprimento da medida é pouco, média de um ano, o trabalho com o adolescente deve ser intenso junto à rede de políticas públicas, com a família, com metodologias eficientes que aproximem a relação entre educador e educando, com profissionais qualificados. É quase uma terapia intensiva. Não é generalizar a característica de adolescente, ele está inserido numa cultura que já existe, dos excluídos, de crime organizado. "Ele se diz ladrão, já tem uma identidade, como transformar esta identidade $¿ "$ (sic). No entanto, quando acontecem casos configurados de "fracasso social”, a sociedade e as instituições reforçam a punição.

A tarefa de execução das Medidas Socioeducativas é um grande desafio pelo fato de ainda ser muito recente. É compreensivo pensar na concepção da sociedade, tendo em vista o histórico cultural, e a dificuldade em aceitar a sociabilidade de uma pessoa que cometeu um crime e não ser castigada. $\mathrm{O}$ adolescente comete um crime e vai para a escola penalidades baseadas na violência legitima, com aplicação de penas de morte banalizadas para servirem de exemplo à população. A mudança de conduta, a transformação do sujeito cidadão é difícil de ser concebida. As equipes envolvidas na aplicação das Medidas tem uma longa estrada para implementar a proposta Socioeducativa e fazer ser aceita socialmente. O ECA só vai ser efetivamente implementado com uma mudança de cultura da sociedade, para viabilizar sua consolidação prática de forma legítima e garantir uma proximidade do ideal de Proteção Integral à criança e ao adolescente. 


\section{CONSIDERAÇÕES FINAIS}

Os resultados da pesquisa de campo evidenciaram a realidade da operacionalização da Medida Socioeducativa de Prestação de Serviços à Comunidade (PSC) no Distrito Federal em relação ao quesito articulação em policy networks, ou seja, a rede de políticas públicas, identificando com a própria equipe de execução desta Medida os desafios, as potencialidades e os limites do trabalho. A análise construída a partir da visão dos profissionais envolvidos na execução da PSC permitiu estabelecer considerações colocadas entre a teoria legislativa, fundamentada nas normas direcionadas no ECA e no SINASE, e a prática desta modalidade do "Programa Socioeducativo $^{61 "}$ (2006, p. 36).

$\mathrm{O}$ atendimento/acolhimento inicial do adolescente realizado pela SEMSE/VIJ/TJDFT consiste de formalidades jurídicas que devem ser cumpridas pela equipe técnica para a efetivação do cumprimento da PSC, mas se estende às ações decorrentes da autonomia dos profissionais que contribuem nas intervenções psicossociais junto aos adolescentes. Da articulação com a rede de políticas públicas, voltada aos adolescentes no DF, é realizada pela equipe da SEMSE sob duas circunstâncias:

1) Formal - encaminhamentos às instituições da rede de políticas públicas indicados pela SEMSE sob solicitação formal de juiz que sugere Medida Protetiva associada à Medida Socioeducativa;

2) Informal - encaminhamentos de adolescentes quando são verificadas pela equipe SEMSE necessidades particulares a partir de avaliação interna da equipe, mesmo sem a prévia solicitação formal do juiz. Nestes casos, ao detectar determinada necessidade, a equipe da SEMSE realiza estudo psicossocial do adolescente como meio de fundamentar e registrar o encaminhamento, bem como prestar uma resposta ao juiz.

Em ambas as formas de interação com a rede de políticas públicas o foco da intervenção realizada pela equipe da SEMSE é o encaminhamento. Segundo a concepção dos profissionais, a função de acompanhamento do adolescente não compete

\footnotetext{
${ }^{61}$ O Programa Socioeducativo é referenciado no SINASE (2006) como o conjunto de ações integrantes do sistema socioeducativo, que são exatamente as quatro modalidades de Medidas: a prestação de serviços a comunidade (citada no trecho), a liberdade assistida, a semiliberdade e a internação.
} 
às equipes de Medidas Socioeducativas, e sim às próprias instituições encaminhadas ou ao Conselho Tutelar, que é responsável legal pelas Medidas Protetivas. O problema que se propaga neste ponto diz respeito a uma operacionalização segmentada das Medidas Socioeducativas às Medidas Protetivas, ou até mesmo a distância entre os Sistemas integrantes do Sistema de Garantia de Direitos (SGD), considerando a dependência contínua sugerida pelo SINASE entre o Sistema Socioeducativos e as instituições representantes das políticas públicas das mais diversas áreas sociais. No caso da PSC, esta articulação é limitada em dois níveis, primeiro entre as instituições internas à execução da Medida Socioeducativa (SEMSE/VIJ e locais de cumprimento da PSC) e em outro plano com relação às estas entidades executoras da PSC e as instituições externas de atenção ao adolescente, disponíveis no DF, ou seja, de rede de políticas públicas. Apesar das reuniões de acolhimento aos adolescentes promovidas entre a VIJ e as entidades de cumprimento da PSC, faz-se necessária a consolidação dos canais intra-institucionais, ligados por vínculos que permitam estabelecer um trabalho em conjunto com troca de informações sobre os adolescentes, para garantir um atendimento de qualidade ao adolescente e à sua família.

O SINASE aponta como componentes da "Comunidade Socioeducativa" a Rede Interna e a Rede Externa de atendimento ao adolescente autor de ato infracional, são as instituições parceiras que executam a Medida Socioeducativa internamente entre os setores dos locais de cumprimento da Medida e externamente entre as equipes que acolhem e aplicam a PSC, no caso. Nota-se na pesquisa a necessidade de uma maior articulação das Redes Socioeducativas citadas, no intuito de compartilhar informações e estabelecer diálogo constante, no sentido de promover um nível de comunicação capaz de aprimorar o atendimento ao adolescente e à sua família, de forma a suprir as necessidades dos mesmos. A função de atualização constante de dados da rede de atenção ao adolescente no DF desempenhada pela assistente social da SEMSE é de extrema importância para que o adolescente seja encaminhado e atendido de forma ágio. Considera-se, neste processo, o acompanhamento do adolescente posterior ao cumprimento da PSC como estratégia importante de continuidade que deveria ser desenvolvida no Sistema Socioeducativo, inclusive para manter contato com as instituições da rede que absorveram este adolescente e sua família. 
No geral, o posicionamento dos profissionais técnicos e coordenadores responsáveis pela PSC a respeito do conceito de "Socioeducativo" permite considerar que o aspecto punitivo ainda é associado ao contexto de cumprimento da Medida Socioeducativa, ao entenderem como meta os objetivos de ressocialização e responsabilização do adolescente equivalente a meios de reparação do dano cometido à sociedade devido o ato infracional. A proposta de reinserção social do adolescente através da Socioeducação, trabalhada nas Medidas, é intencionada no sentido de moldar o adolescente aos valores e normas sociais vigentes, ou seja, adequá-lo aos padrões de vivência em sociedade, como se antes ele não fosse identificado como um sujeito social $^{62}$. Todavia, a oportunidade que a PSC representa para o adolescente que cometeu ato infracional vai além da intenção de cumprir sua dívida social e mudá-lo por meio da reflexão educativa, mas consiste em fornecer condições do mesmo atuar na sociedade como cidadão contemplado em seus direitos. Para tanto, faz-se necessário que os adolescentes sejam assegurados em seus direitos e conscientizados de seus deveres, tarefa que deve ser iniciada com a mobilização da "Comunidade Socioeducativa". Mesmo que por via da situação infracional, carregada socialmente de peso recriminatório pela atitude cometida, é no espaço Socioeducativo que o adolescente tem um contato próximo com a conscientização de seus direitos e deveres, cabendo às instituições aproveitar do papel fundamental de acolhimento para transformar o adolescente contemplando suas necessidades, por meio de mecanismos colaborativos entre instituições e serviços componentes da rede de políticas públicas.

Analisa-se como carência do Sistema Socioeducativo do DF a ausência de um Projeto Pedagógico específico para a realidade regional que norteei os métodos de intervenção Socioeducativos trabalhados nos locais de cumprimento da PSC. A contribuição acadêmica dos coordenadores envolvidos na PSC é entendida como aspecto importante diante das condições estruturais de funcionamento, por se tratarem de voluntários e empregados sem vínculo formal com a instituição. No entanto, o

\footnotetext{
${ }^{62}$ Atenta-se para o significado da colocação "reinserção social" que pode dizer respeito à incapacidade do adolescente interagir como cidadão por está envolvido em situação de periculosidade, que o levou a cometer $\mathrm{o}$ ato infracional. No entanto, considero que o adolescente autor de ato infracional já se encontrava inserido na sociedade, apesar de marginalizados em algum aspecto de vulnerabilidade social ou individual, considerando que a situação infracional não se restringe às desigualdades entre classes sociais. O reconhecimento do adolescente como cidadão implica em atender suas necessidades pessoais e sociais por meio do apoio das políticas públicas de acesso aos seus direitos.
} 
diferencial observado entre a dinâmica de atividades desenvolvidas no PESC/UnB e no AVHUB é evidente em seu andamento. A assistente social responsável pelo PESC elaborou instrumentais de suporte ao acompanhamento do adolescente e desenvolveu em oficinas uma didática educativa voltada ao objetivo de promover a reflexão do jovem sobre sua história de vida de maneira a atingi-lo em sua auto-estima para que se reconheça como ator social. A assistente social buscou se engajar em cursos de formação para aprofundar sua contribuição no Projeto e consolidar uma dinâmica Socioeducativa capaz de tocar o adolescente.

Já a abordagem terapêutica conduzida pela psicoterapeuta no AVHUB aplica um método, inclusive segundo seu depoimento, desprovido do fator pedagógico. A intervenção psicológica que é desempenhada nas reuniões coletivas com os adolescentes possui um caráter impactante positivo para o adolescente, em sua subjetividade. Portanto, as duas medidas contemplam o objetivo de atingir o adolescente em si de formas diferentes. No entanto, pelo atendimento não ser individualizado e pelas dificuldades estruturais e materiais de funcionamento, as equipes dos locais de cumprimento dos serviços não desempenham um trabalho de articulação com a rede de políticas públicas no sentido de contar com parceiros ou de viabilizar acesso direito ao jovem. Nesta questão, tanto a psicoterapeuta da AVHHUB quanto a profissional de Serviço Social do PESC não exercem a função de articular em rede, apesar de reconhecer esta frente de atendimento como essencial, inclusive como eixo que poderia ampliar os horizontes da intervenção Socioeducativa junto ao adolescente e a sua rede social, principalmente sua família. O limite da rede utilizada pelos coordenadores da PSC nos locais de cumprimento da Medida é referente aos Centros de Custos dos convênios, onde os adolescentes prestam os serviços durante o tempo determinado judicialmente e são acompanhados.

Diante dos empecilhos estruturais apresentados que impedem as equipes de PSC desenvolverem amplamente intervenções técnicas nas áreas de jurídica, saúde, psicológica, social e pedagógica; o psicólogo da SEJUS alertou a importância do trabalho Socioeducativo ser pautado nos quatro pilares da educação sugeridos no relatório de Deloirs: aprender, conviver, fazer e ser. A construção do SIDASE, como Projeto Político Pedagógico local do Sistema Socioeducativo, é uma conquista que vai balizar um atendimento adequado à realidade distrital. Considerando que "o SINASE 
será custeado com recursos do orçamento da seguridade social” (2006, p. 71), assim como de outras fontes do Fundo da Criança e do Adolescente, a relação entre políticas públicas se faz legítima e necessária para um atendimento que contemple a Proteção Integral do adolescente autor de ato infracional. A esperança depositada na SEJUS como secretaria do Poder Executivo, em facilitar a aplicação da PSC, aparece como desafio para as equipes que já enfrentam a execução da LA.

As incertezas quanto à política central sob a qual as Medidas Socioeducativas devem estar submetidas podem ser esclarecidas quando analisados os eixos dos parâmetros socioeducativos dispostos no SINASE, são eles: Eixo - Diversidade étnicoracial, gênero e orientação sexual, Eixo - Educação, Eixo - Esporte, Cultura e Lazer, Eixo - Saúde, Eixo - Abordagem familiar e comunitária, Eixo - Profissionalização/ Trabalho/Previdência, Eixo - Segurança (2006). A área de Direitos Humanos engloba ações e programas que tem por diretriz oferecer e garantir acesso destas políticas ao usuário. O Sistema Socioeducativo deve funcionar de forma articulada com as alianças estratégias estabelecida entre instituições, programas e serviços das diversas áreas sociais, para, assim, viabilizar o acesso às políticas públicas, entendendo que

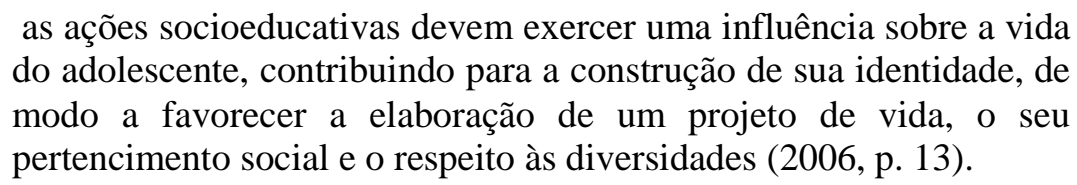

Concluindo, espera-se que este trabalho de conclusão de curso represente um material que sirva de base bibliográfica a demais produções da área interessadas em explorar assuntos que envolvam a temática da adolescência em situação infracional, relacionada às redes de políticas públicas. O papel do Serviço Social na execução da PSC foi situado como fundamental tanto no atendimento jurídico junto ao adolescente quanto no diferencial apresentado na dinâmica de atividades Socioeducativas desenvolvida nos locais de cumprimento pesquisados. Como profissão engajada nas equipes de operacionalização desta Medida, sua função no trabalho de articulação com as redes de políticas públicas deve ser assumido como objetivo prático a ser desempenhado em prol da transformação/emancipação do adolescente. Os profissionais devem conceber o trabalho em rede como ferramenta de intervenção capaz de contemplar as necessidades dos adolescentes que cometeram ato infracional, por causas que devem ser sanadas em suas raízes, para evitar reincidência e garantir a devolução do que são nada mais do que direitos, o acesso às políticas públicas. 


\section{CRONOGRAMA}

Etapa 1 - Revisão de bibliografia.

Etapa 2 - Elaboração do Projeto de Trabalho de Conclusão de Curso.

Etapa 3-Realização da pesquisa de campo - Coleta de dados, entrevistas.

Etapa 4 -Análise de dados e elaboração do TCC.

Etapa 5 - Apresentação - Defesa de TCC.

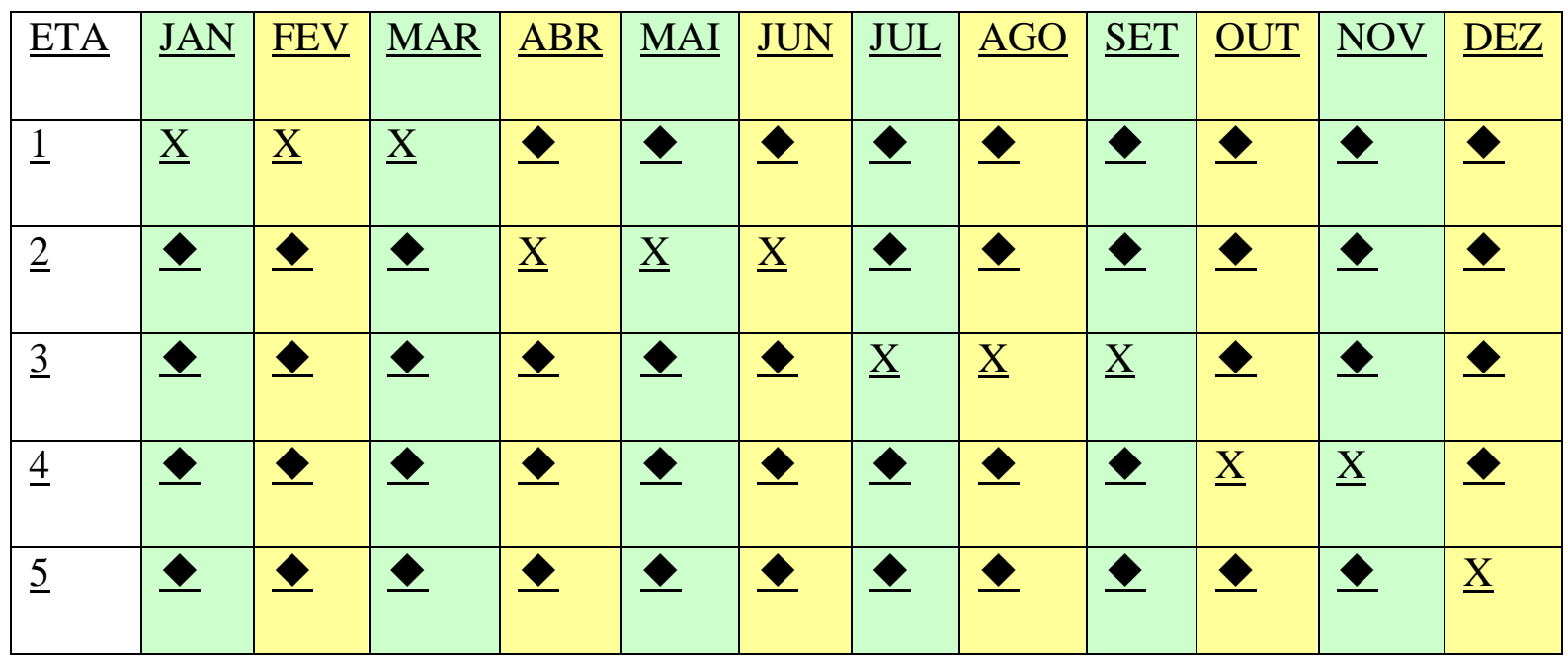

ORÇAMENTO

\begin{tabular}{|l|l|}
\hline MATERIAIS & DESPESAS \\
\hline Cópias/Impressão & $\mathrm{R} \$ 50,00$ \\
\hline Pilha de gravador & $\mathrm{R} \$ 7,00$ \\
\hline Gasolina & $\mathrm{R} \$ 50,00$ \\
\hline TOTAL: & $\mathrm{R} \$ 107,00$ \\
\hline
\end{tabular}




\section{REFERÊNCIAS BIBLIOGRÁFICAS:}

- AIRES, P. "História social da criança e da família, RJ : Livros técnicos e científicos, 1981, p. 9-164.

- ANTUNES, R. Adeus ao trabalho? "Ensaio sobre as metamorfoses e a centralidade do mundo do trabalho". Campinas, SP, Cortez, - 1995 - 2003.

- AGUIAR, M. J. ; ANDER-EGG E. "Avaliação de Serviços e Programas Sociais”. Ed. Vozes. Petrópolis. 1994, p. 15- 86.

- ARANTES, E. M. de M. "Rostos de crianças no Brasil. In: PILOTTI, F. e RIZZINE, I. A Arte de Governar Crianças. RJ: Amais Ed. Instituto Interamericano Del Niño, 1995.

- BARBOSA, Eni Maria Monteiro. “Os Direitos da Criança e a Assistência Social”. Disponível em http://www.abmp.org.br/textos/429.htm. Acesso em 10 de novembro de 2009.

- BAZÍLIO, L. C. “O menor e a ideologia de segurança nacional”. BH: Veja - Novo Espaço, 1985.

- BRASIL, Estatuto da Criança e do Adolescente. Lei 8.069/90. SEDH, MEC, Brasília, 2005.

- BRASIL, Lei Orgânica de Assistência Social. Lei 8.742/1993. LOAS - $6^{\text {a }}$ Ed. Brasília: MDS, 2007.

- BRASIL, Sistema Nacional Socioeducativo - SINASE/Secretaria Especial dos Direitos Humanos - Brasília - DF: CONANDA, 2006.

- BRASIL, "Rede de Atenção à Criança e ao Adolescente no Distrito Federal". Promotoria de Justiça de Defesa da Infância e da Juventude. ACS. $5^{\text {a }}$ Edição - junho 2006.

- BRASIL. Presidência Da República. Secretaria Especial Dos Direitos Humanos Subsecretaria De Promoção Dos Direitos Da Criança E Do Adolescente. Levantamento Nacional Do Atendimento Socioeducativo Ao Adolescente Em Conflito Com A Lei Foi Realizado No Período De 01/08/2006 A 15/08/2006.

- BRASIL, MINISTÉRIO DO DESENVOLVIMENTO SOCIAL E COMBATE À FOME SECRETARIA NACIONAL DE ASSISTÊNCIA SOCIAL POLÍTICA NACIONAL DE ASSISTÊNCIA SOCIAL, Brasília, Setembro, 2004.

- BOSCHETTI, I. ; BEHRING, E. "Política Social: fundamentos e história". Biblioteca básica de Serviço Social. SP - Vol. 2. Ed. Cortez, 2006.

- BOSCHETTI I., Orgs. "Política Social no Capitalismo. Tendências Contemporâneas". - SP - Ed. Cortez, 2008.

- CARVAJAL, G. "Tornar-se adolescente. A aventura de uma metamorfose". SP: Ed. Cortez, 1998.

- CEPAL; FNUAP. “Juventud, Población y desarrollo em América Latina y El Caribe”. Problemas, oportunidades y desafios. Chile, 2000. 
- CINTRA, Talita Teobaldo. “A implantação da política de assistência social no Distrito Federal: mapeamento e análise da rede de proteção social especial de alta complexidade na dinâmica socioespacial". Brasília. Monografia - UnB, 2007.

- COELHO, A.B. de S.R. "A política social voltada à proteção à infância e juventude no Brasil, In. Política de proteção à infância e adolescência e descentralização: o caso do

conselho de direitos da criança e do adolescente de João Pessoa - PB, Dissertação de mestrado em Serviço Social - UFPB, 1997, pp.42-62.

- DEL PRIORE, M. Org. "História das crianças no Brasil". 5. Ed. - SP: Contexto, 2006.

- FALEIROS, Vicente de Paula. "Infância e Adolescência: trabalhar, educar, punir, assistir, proteger". Caderno Especial nº19 - 15 anos do Estatuto da Criança e do Adolescente. Edição: 29 de julho a 12 de agosto de 2005.

- FALEIROS, V. P. “A Política Social do Estado capitalista”. 11ª Edição. SP: Ed. Cortez. 2008.

- FREY, Klaus. "Políticas Públicas: Um Debate Conceitual e Reflexões Referentes à Pratica da Análise de Políticas Públicas no Brasil". Planejamento e Políticas Públicas, No 21 - JUN, 2000.

-- HOCHMAN, G. "Quando a saúde se torna pública...”. In: A Era do saneamento. SP, Cortez Ed, 1998.

- KLIJN, E. H. "Redes de Políticas Públicas: Una Visión General” Managing Complex Networks. Sage, London, 1998.

- LAVINAS, L. "Pobreza e Exclusão: traduções regionais de duas categorias da prática”. Econômica, v. 04, n. 1, p. 25-59. SP: impressa em outubro, 2003.

- LIMA, A. D. de. "As regras legais e o processo de descentralização da Assistência Social”. Ser Social 12. Política de Assistência Social. Brasília, UnB, 1998. p. 87-114.

- MOTA, A.E. "Seguridade Social Brasileira". In. Serviço Social e Saúde: formação e trabalho profissional. SP, Cortez, 2005.

- LEVISKY, D. L. “Adolescência e violência”. Ed. Artes médicas.Porto Alegre, 1997.

- LODI, J. B. “A entrevista. Teoria e prática. $7^{\text {a }}$ Ed. Biblioteca pioneira de administração e negócios. SP, 1991.

- MACEDO, Mariano de Matos. "Agências de Desenvolvimento e Policy Networks: noções conceituais e exemplos das experiências internacional e nacional noções conceituais e exemplos das experiências internacional e nacional", $R$. paran. Desenv., Curitiba, n.96, p. 49-76, maio/ago. 1999.

- MACÍLIO, M. L. "História social da criança abandonada, SP: Hucitec, 1998.

- Manual de Orientação - Medidas Sócio -Educativas Não Privativas de Liberdade. Secretaria de Cidadania e Trabalho Superintendência da Criança, do Adolescente e da Integração do Deficiente. Av. Universitária $n^{\circ}$ 609, Setor Universitário - Goiânia Goiás. Março /2000. 
- MARCONI, M. de A; LAKATOS, E. M. “Técnicas de Pesquisa”. SP: ATLAS, 1982.

- MARTES, Ana Cristina Braga et. al. "Fórum - Redes Sociais e Interorganizacionais", RAE. 2006.

- MARTINELLI, M. L. “Serviço Social Identidade e Alienação”. Ed. Cortez. 1989.

- MIONE, A. S. “(In)visibilidade Perversa: Adolescentes Infratores como Metáfora da Violência”. - SP- Cortez, 2007.

- NOVAES, R. "Redes de Políticas Públicas e Gestão de Recursos Hídricos; perspectivas e contribuições teórico-metodológicas da abordagem de "policy networks". 2000. In: II Encontro da Associação Nacional de Pós-Graduação e Pesquisa em Ambiente e Sociedade ANPPAS, 2004, Indaiatuba. II Encontro da Associação Nacional de Pós-Graduação e Pesquisa em Ambiente e Sociedade ANPPAS, 2004.

- OLIVETO, Paloma. "Rigor em excesso", Correio Braziliense. Em 13/02/2009 - 08:28.

- PASSETTI, E. et. al. "Violentados: criança, adolescente e justiça". SP: Ed. Imaginário, 1999.

- PAIVA, Denise Maria Fonseca - "Mapeamento Nacional Da Situação Do Atendimento Dos Adolescentes Em Cumprimento De Medidas Sócioeducativas. Sumário Executivo". Subsecretaria de Promoção dos Direitos da Criança e do Adolescente. 2002.

- PEREIRA, P. A. “Discussões conceituais sobre política social”. 2008.

- PEREIRA, P. A. "Necessidades Humanas. Subsídios à crítica dos mínimos sociais". 4" Edição. SP: Ed. Cortez, 2007.

- Regras Mínimas de Beijing. "Regras Mínimas das Nações Unidas para a Administração da Justiça, da Infância e da Juventude". FUNABEM. 1998.

- ROCHA, S. "Pobreza no Brasil. Afinal, de que se trata¿” Ed. FGV. Capitulo 7, 2000. p. 175-193.

- RODRIGUES, J. A. M. "Análise de redes e políticas de juventude”. Brasília, UnB, Mestrado, Instituto de Ciências Políticas. 2008.

- SALES, M. A. “(In)visibilidade perversa: Adolescentes infratores como metáfora da violência, SP: Cortez, 2007, p. 21-96.

- SANTOS, Hermílio. "Perspectivas contemporâneas para a constituição de redes de políticas públicas”. Civitas Porto Alegre v. 5 n. 1 jan.-jun. 2005.

- SANTOS, D.A.F. "Prestação de Serviços á Comunidade: Medida socieducativa que contribui para a (re)inserção do adolescente infrator ¿”. UnB. IH. SER, 2000.

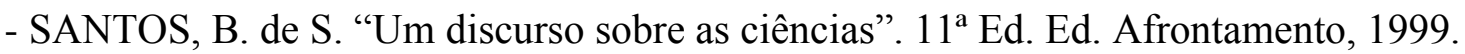

- TEDESCO \& LIBERMAN. "O que fazemos quando falamos em Vulnerabilidade?" O Mundo da Saúde São Paulo: 2008: abr/jun 32(2):254-260. 
- VALLADARRES, Licia. "Cem anos pensando a pobreza (urbana) no Brasil”. RJ, 1991.

- VARALDA, Renato Barão. "Políticas Públicas Infanto-Juvenis". 2009. Disponível em www.mpdft.gov.br/...

- VERONESE, J. R. P. et. al. "Infância e Adolescência, O Conflito com a Lei: algumas discussões”. Florianópolis. Fundação BOITEUX, 2001.

- VOLPI, M (org). “O Adolescente e o Ato Infracional”, SP, Cortez, 1999.

- WORTHEN, B. R. et at. “Avaliação de Programas. Concepções e práticas”. Ed. USP. 2003, p. $33-95$. 
$\underline{\text { ANEXO } 1}$

\section{FLUXOGRAMA DE RESPONSABILIZACCAO DO ADOLESCENTE AUTOR DE ATO INFRACIONAL}

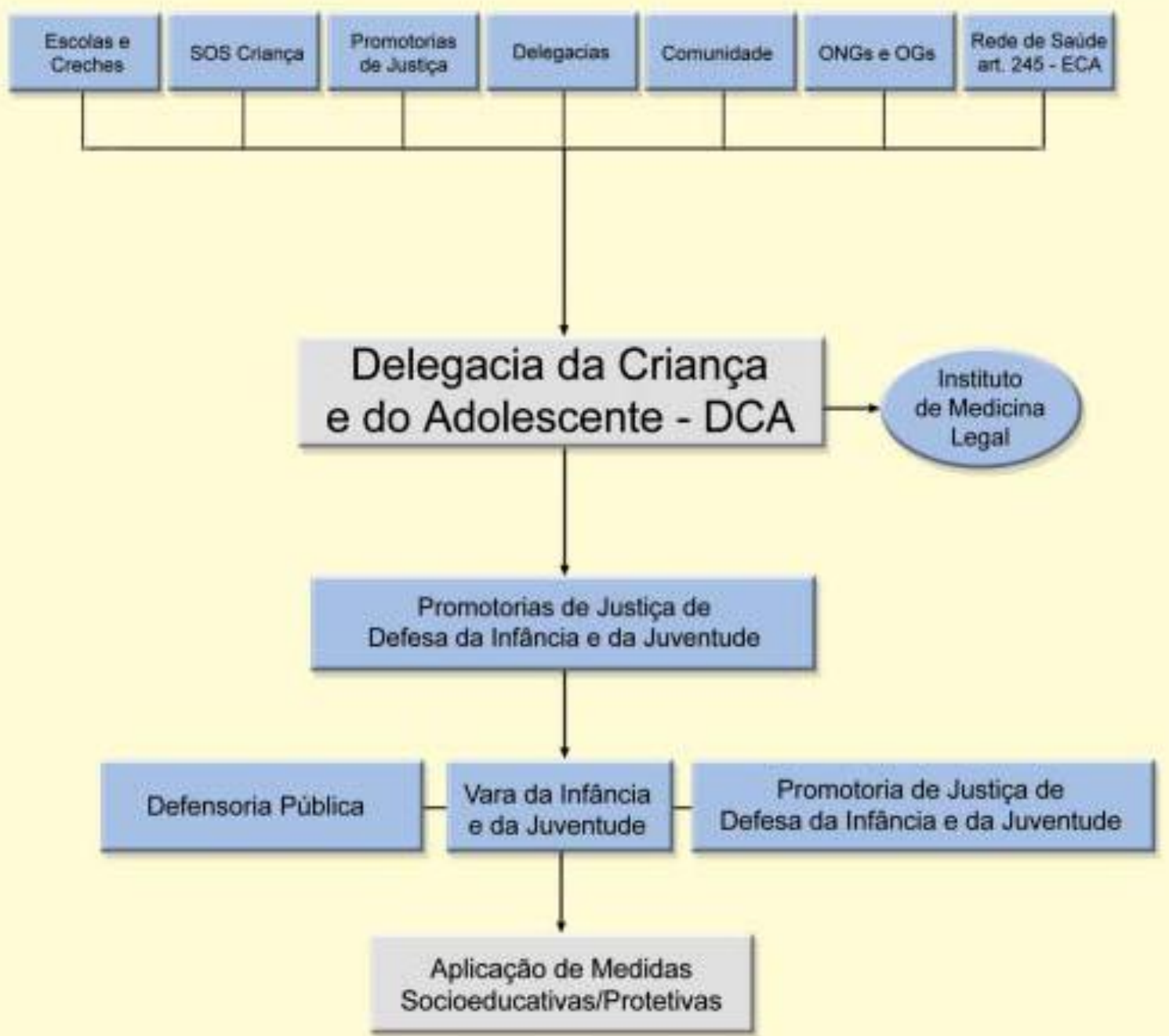

FONTE: Disponível em: http://www.mpdft.gov.br/joomla/pdf/cartilhas/Cartilha_Rede_de_Atencao.pdf 


\section{ROTEIRO DE ENTREVISTA - VIJ e Entidades de Prestação de Serviços}

1) Qual sua formação acadêmica e qual seu vínculo com esta instituição?

2) Como você se engajou na operacionalização da PSC, desde quando?

3) O que você entende sobre o conceito de "Sócio-educativo", qual sua definição?

4) Em que consiste o trabalho desempenhado pelas equipes, como funciona a execução da PSC?

5) Os profissionais conhecem as instituições e serviços integrantes da Rede de Atenção ao Adolescente no DF? Quais?

6) Quais são as principais instituições parceiras da rede?

7) Como é identificada a necessidade de acionar a rede, em que casos e em que momento são feitos os encaminhamentos?

8) De que forma é realizada interlocução com a Rede de Atenção ao Adolescente, ou seja, com as políticas públicas?

9) As equipes conhecem as diretrizes do SINASE, entre eles o objetivo de articulação com a Rede de Políticas Públicas?

10) Qual a importância atribuída à utilidade do trabalho articulado com a Rede de Atenção ao Adolescente na aplicação da PSC?

11) Há acompanhamento posterior ao cumprimento da PSC do adolescente no intuito de verificar sua inserção em instituições da rede?

12) Os recursos administrativos, financeiros e humanos disponíveis são suficientes para desempenhar um trabalho articulado com a rede de políticas públicas?

13) Quais os desafios enfrentados em estabelecer articulação com a Rede de Atenção ao Adolescente disponível no DF? 
$\underline{\text { ANEXO } 3}$

ROTEIRO DE ENTREVISTA - Servidor da SEJUS

1) Como se deu o processo de discussão que culminou na transição da responsabilidade de gestão das Medidas Socioeducativas para a Secretaria de Justiça e Direitos Humanos - SEJUSDH? Que representantes e instituições participaram?

2) Qual o objetivo da mudança de secretaria e quais os projetos da SEJUS para adequar a operacionalização das Medidas Socioeducativas à proposta do SINASE, em especial o trabalho articulado em redes de políticas públicas?

3) Como funcionará a execução da Medida de Prestação de Serviços à Comunidade? 
$\underline{\mathrm{ANEXO} 4}$

UNIVERSIDADE DE BRASÍLIA - UNB

INSTITUTO DE CIÊNCIAS HUMANAS - IH

DEPARTAMENTO DE SERVIÇO SOCIAL - SER

TRABALHO DE CONCLUSÃO DE CURSO

Termo de Consentimento Livre e Esclarecido

$\mathrm{Eu}$, de idade,

concordo em participar da entrevista e colaborar, por minha livre e espontânea vontade, com a pesquisa social "Operacionalização das Medidas Socioeducativas e a Articulação com a Rede de Atenção ao Adolescente no Distrito Federal: um Olhar da Equipe Executora da Prestação de Serviços à Comunidade (PSC)" que será apresentada pela pesquisadora discente Annie Vieira Carvalho no Trabalho de Conclusão de Curso do Departamento de Serviço Social/UnB para fins de formação e obtenção do grau de nível superior.

Declaro está esclarecido dos objetivos da pesquisa em analisar em que medida as equipes executoras da Prestação de Serviços a Comunidade desenvolvem, na operacionalização da Medida Socioeducativa, um trabalho de articulação com a Rede de Atenção ao Adolescente no Distrito Federal. Reconheço, ainda, que me será garantido o sigilo no trabalho escrito e oral através do anonimato, bem como o direito de retirar o consentimento a qualquer momento, diante de possíveis desconfortos ou quaisquer circunstâncias. A pesquisadora estará à disposição para prestar esclarecimentos.

Data:

Entrevistada (o):

Entrevistadora:

\section{CONTATOS:}

Pesquisadora Annie V. Carvalho - email: annie.carvalho@gmail.com / Tel: 91360214

Orientador Mario Ângelo - email: maran@unb.br

CEP/IH: cep_ih@unb.br

DEPARTAMENTO DE SER/UnB : 33072290 